\title{
Pentoxifylline for intermittent claudication (Review)
}

Salhiyyah K, Forster R, Senanayake E, Abdel-Hadi M, Booth A, Michaels JA

Salhiyyah K, Forster R, Senanayake E, Abdel-Hadi M, Booth A, Michaels JA. Pentoxifylline for intermittent claudication.

Cochrane Database of Systematic Reviews 2015, Issue 9. Art. No.: CD005262. DOI: 10.1002/14651858.CD005262.pub3. 
HEADER 1

ABSTRACT

PLAIN LANGUAGE SUMMARY

BACKGROUND

OBJECTIVES

METHODS

RESULTS

Figure 1.

Figure 2.

Figure 3.

DISCUSSION

AUTHORS' CONCLUSIONS

ACKNOWLEDGEMENTS

REFERENCES

CHARACTERISTICS OF STUDIES

ADDITIONAL TABLES

APPENDICES

WHAT'S NEW

HISTORY

CONTRIBUTIONS OF AUTHORS

DECLARATIONS OF INTEREST

SOURCES OF SUPPORT

DIFFERENCES BETWEEN PROTOCOL AND REVIEW

INDEX TERMS

\section{TABLE OF CONTENTS}


[Intervention Review]

\section{Pentoxifylline for intermittent claudication}

Kareem Salhiyyah ${ }^{1}$, Rachel Forster ${ }^{2}$, Eshan Senanayake ${ }^{3}$, Mohammed Abdel-Hadi ${ }^{4}$, Andrew Booth ${ }^{5}$, Jonathan A Michaels ${ }^{5}$

1Wessex Cardiothoracic Centre, University Hospital Southampton, Southampton, UK. ${ }^{2}$ Centre for Population Health Sciences, University of Edinburgh, Edinburgh, UK. ${ }^{3}$ Department of Surgery, Northern General Hospital, Sheffield, UK. ${ }^{4}$ Department of Cardiology and Vascular Diseases, Herz- u. Kreislaufzentrum Rotenburg, Rotenburg, Germany. ${ }^{5}$ School of Health and Related Research, University of Sheffield, ScHARR, Sheffield, UK

Contact address: Kareem Salhiyyah, Wessex Cardiothoracic Centre, University Hospital Southampton, Tremona Road, Southampton, SO166YD, UK. kareemsal@doctors.net.uk.

Editorial group: Cochrane Vascular Group.

Publication status and date: New search for studies and content updated (no change to conclusions), published in Issue 9, 2015.

Citation: Salhiyyah K, Forster R, Senanayake E, Abdel-Hadi M, Booth A, Michaels JA. Pentoxifylline for intermittent claudication. Cochrane Database of Systematic Reviews 2015, Issue 9. Art. No.: CD005262. DOI: 10.1002/14651858.CD005262.pub3.

Copyright @ 2015 The Cochrane Collaboration. Published by John Wiley \& Sons, Ltd.

\section{A B S T R A C T}

\section{Background}

Intermittent claudication (IC) is a symptom of peripheral arterial disease (PAD) and is associated with high morbidity and mortality. Pentoxifylline, one of many drugs used to treat IC, acts by decreasing blood viscosity, improving erythrocyte flexibility and promoting microcirculatory flow and tissue oxygen concentration. Many studies have evaluated the efficacy of pentoxifylline in treating individuals with PAD, but results of these studies are variable. This is an update of a review first published in 2012.

\section{Objectives}

To determine the efficacy of pentoxifylline in improving the walking capacity (i.e. pain-free walking distance and total (absolute, maximum) walking distance) of individuals with stable intermittent claudication, Fontaine stage II.

\section{Search methods}

For this update, the Cochrane Vascular Group Trials Search Co-ordinator searched the Specialised Register (last searched April 2015) and the Cochrane Register of Studies (2015, Issue 3).

\section{Selection criteria}

All double-blind, randomised controlled trials (RCTs) comparing pentoxifylline versus placebo or any other pharmacological intervention in patients with IC Fontaine stage II.

\section{Data collection and analysis}

Two review authors separately assessed included studies,. matched data and resolved disagreements by discussion. Review authors assessed the methodological quality of studies by using the Cochrane 'Risk of bias' tool and collected results related to pain-free walking distance (PFWD) and total walking distance (TWD). Comparison of studies was based on duration and dose of pentoxifylline.

\section{Main results}

We included in this review 24 studies with 3377 participants. Seventeen studies compared pentoxifylline versus placebo. In the seven remaining studies, pentoxifylline was compared with flunarizine (one study), aspirin (one study), Gingko biloba extract (one study), nylidrin hydrochloride (one study), prostaglandin E1 (two studies) and buflomedil and nifedipine (one study). The quality of the evidence was generally low, with large variability in reported findings.. Most included studies did not report on random sequence generation and allocation concealment, did not provide adequate information to allow selective reporting to be judged and did not report blinding of 
assessors. Heterogeneity between included studies was considerable with regards to multiple variables, including duration of treatment, dose of pentoxifylline, baseline walking distance and participant characteristics; therefore, pooled analysis was not possible.

Of 17 studies comparing pentoxifylline with placebo, 14 reported TWD and 11 reported PFWD; the difference in percentage improvement in TWD for pentoxifylline over placebo ranged from $1.2 \%$ to $155.9 \%$, and in PFWD from $-33.8 \%$ to $73.9 \%$. Testing the statistical significance of these results generally was not possible because data were insufficient. Most included studies suggested improvement in PFWD and TWD for pentoxifylline over placebo and other treatments, but the statistical and clinical significance of findings from individual trials is unclear. Pentoxifylline generally was well tolerated; the most commonly reported side effects consisted of gastrointestinal symptoms such as nausea.

\section{Authors' conclusions}

Given the generally poor quality of published studies and the large degree of heterogeneity evident in interventions and in results, the overall benefit of pentoxifylline for patients with Fontaine class II intermittent claudication remains uncertain. Pentoxifylline was shown to be generally well tolerated.

Based on total available evidence, high-quality data are currently insufficient to reveal the benefits of pentoxifylline for intermittent claudication.

\section{PLAIN LANGUAGE SUMMARY}

\section{Pentoxifylline for intermittent claudication}

\section{Background}

Atherosclerosis, or hardening of the arteries, results in narrowing and blockage of the arteries and can reduce the blood supply to the legs, causing peripheral arterial disease. Intermittent claudication (IC) is a cramp-like pain felt in the leg muscles that is brought on by walking and is relieved by standing still or resting. Pentoxifylline is a drug that is used to relieve IC while improving people's walking capacity. It decreases blood viscosity and improves red blood cell flexibility, promoting microcirculatory blood flow and increasing oxygen in the tissues. This review looked at all available evidence from randomised controlled trials on the efficiency of pentoxifylline for treatment of IC.

\section{Study characteristics and key results}

This review included 24 studies with 3377 participants (current until April 2015). Seventeen studies compared pentoxifylline with placebo, and the remaining studies compared pentoxifylline with flunarizine (one study), aspirin (one study), Gingko biloba extract (one study), nylidrin hydrochloride (one study), prostaglandin E1 (two studies) and buflomedil and nifedipine (one study). Large differences between included studies in how investigators measured and reported study findings made it impossible to combine results.

Most of the included studies suggested mild to moderate improvement in pain-free walking distance and total walking distance for pentoxifylline over placebo (and other treatments, which included Gingko biloba, buflomedil, iloprost, nylidrin, aspirin and prostaglandin E1). The statistical significance of findings from individual trials was unclear, and researchers observed large variability between studies in the effects of pentoxifylline. The most commonly reported side effects were gastrointestinal symptoms, mainly nausea, and the drug was well tolerated.

\section{Quality of the evidence}

The quality of included studies was generally low, and very large variability between studies was noted in reported findings including duration of trials, doses of pentoxifylline and distances participants could walk at the start of trials. Most included studies did not report on randomisation techniques or how treatment allocation was concealed, did not provide adequate information to permit judgement of selective reporting and did not report blinding of outcome assessors. Given all these factors, the role of pentoxifylline in intermittent claudication remains uncertain, although this medication was generally well tolerated by participants. 


\section{B A C K G R O U N D}

\section{Description of the condition}

Intermittent claudication (IC) is a cramp-like pain felt in the leg muscles that is brought on by walking, is relieved by rest and is a result of reduced circulation (NICE 2012). Intermittent claudication is a common presentation of peripheral arterial disease (PAD) caused by atherosclerosis. From 2000 to 2010, the number of people living with PAD increased across all age groups by a mean of $23.51 \%$ (Fowkes 2013). These data include high-income countries, as well as low- and middle-income countries. Peripheral arterial disease is a progressive disease associated with significant morbidity and mortality. The main cause of mortality is associated cerebrovascular and coronary artery disease. Patients with IC have reduced quality of life and increased risks of stroke and myocardial infarction (NICE 2011).

\section{Description of the intervention}

Primary health care plays an important role in the treatment of individuals with intermittent claudication. First steps in treating IC include conservative risk factor control, exercise therapy and pharmacotherapy (Tendera 2011). Revascularisation intervention, in the form of open or endovascular surgery, is usually reserved for incapacitating disease (Bachoo 2010; Fowkes 1998). In one study, $63 \%$ of newly diagnosed claudicants were treated by general practitioners with lifestyle advice or drugs, or both; only $37 \%$ required referral to hospital specialists (Meijer 2002). Understanding treatment options and their effectiveness is vital for controlling the disease at an early stage and preventing its progression.

Different types of medications have been used for treatment of IC. Vasodilators and antiplatelets reduce the chance of blood clots at the blockage site (Wong 2011); other drugs help reduce the symptoms of claudication, improve walking distance and reduce disability associated with the condition (de Backer 2012; de Backer 2013; Robertson 2013).

\section{How the intervention might work}

Pentoxifylline is a vasoactive drug that has been authorised for the medical treatment of individuals with IC. Pentoxifylline decreases blood viscosity, improves erythrocyte flexibility and promotes microcirculatory flow, while increasing tissue oxygen concentration. It is a methylxanthine derivative that works by inhibiting the enzyme phosphodiesterase and by potentiating the effects of endogenous prostacyclin, a prostaglandin that possesses anti-aggregatory, fibrinolytic (decreased fibrinogen concentrations) and vasodilatory properties and increases cyclic adenosine monophosphate (cAMP) levels in red blood cells, platelets and arterial cell walls (Micromedex 2002).

\section{Why it is important to do this review}

Intermittent claudication is a marker of increased morbidity and mortality, and treating symptoms is becoming ever more important with the increased prevalence of PAD. Previous studies and reviews have evaluated the efficacy of pentoxifylline in the treatment of IC and peripheral vascular disease, compared with other treatment options including other pharmacological interventions and exercise, yielding variable results (Bedenis 2014; Lane 2014; Moher 2000; Stevens 2012). Continued evaluation of pentoxifylline through evidence-based systematic reviews will result in improved understanding of available pharmacological interventions for IC.

Recently, the National Institute for Health and Care Excellence (NICE) recommended naftidrofuryl oxalate as the leading pharmacological treatment for IC on studies of effectiveness and costs (NICE 2011; NICE 2012). In this review, we will not address costeffectiveness.

\section{O B JECT IVES}

To determine the efficacy of pentoxifylline in improving the walking capacity (i.e. pain-free walking distance and total (absolute, maximum) walking distance) of individuals with stable intermittent claudication, Fontaine stage II (Fontaine 1954).

\section{METHODS}

\section{Criteria for considering studies for this review}

\section{Types of studies}

We included all double-blind, randomised controlled trials of pentoxifylline versus placebo or versus other pharmacological interventions. We excluded comparisons with diet, exercise or surgery. We excluded single-blind and open studies.

\section{Types of participants}

We included patients with symptoms of stable IC (no change in symptoms for six months), Fontaine stage II (Fontaine 1954), due to peripheral vascular disease. We excluded those with symptoms of critical ischaemia (rest pain, skin ulcers or gangrene) or who had undergone previous surgical or percutaneous catheter interventions.

\section{Types of interventions}

We included studies that compared pentoxifylline versus placebo or some other pharmacological intervention and lasted at least four weeks. We excluded comparisons with surgery, angioplasty or exercise. We included all doses and routes of administration of pentoxifylline.

\section{Types of outcome measures}

\section{Primary outcomes}

Walking capacity is one of the most important outcome measures used to assess intermittent claudication.

According to Moher 2000, walking capacity can be assessed by

- pain-free walking distance (PFWD) or initial claudication distance (ICD), which is the distance walked on a treadmill before the onset of pain; and

- total walking distance (TWD) or absolute claudication distance (ACD), which is the maximum or absolute distance walked on a treadmill.

\section{Secondary outcomes}

- Ankle-brachial pressure index (ABI).

- Quality of life, as measured by questionnaires.

- Side effects. 
In this review, we excluded outcome measures such as blood viscosity and microcirculation.

\section{Search methods for identification of studies}

We applied no language restrictions in our searches, and we sought translation of non-English trials.

\section{Electronic searches}

For this update, the Cochrane Vascular Group Trials Search Coordinator (TSC) searched the Specialised Register (last searched April 2015) and the Cochrane Register of Studies (CRS) (http:// www.metaxis.com/CRSWeb/Index.asp) (2015, Issue 3), which is part of the Cochrane Library (www.cochranelibrary.com). See Appendix 1 for details of the search strategy used in searching the CRS. The Specialised Register is maintained by the TSC and is constructed from weekly electronic searches of MEDLINE, EMBASE, CINAHL, AMED, and through handsearching relevant journals. The full list of the databases, journals and conference proceedings which have been searched, as well as the search strategies used are described in the Specialised Register section of the Cochrane Vascular Group module in the Cochrane Library (www.cochranelibrary.com).

\section{Searching other resources}

We reviewed the reference lists of all relevant, identified studies.

\section{Data collection and analysis}

\section{Selection of studies}

Two review authors (KS and RF) used the eligibility criteria provided above to independently assess all potentially relevant articles identified by the search strategy described. We resolved differences by consensus.

\section{Data extraction and management}

KS and RF collected information from each included trial. Information collected included trial design, participant characteristics, inclusion and exclusion criteria, interventions and controls used, treatment periods, methods of assessment and PFWD and TWD results. We also collected data on the secondary outcomes of ankle-brachial pressure index (ABI), quality of life and side effects.

\section{Assessment of risk of bias in included studies}

For the update of this review, two review authors (RF and KS) assessed the quality of included studies using the 'Risk of bias' tool described in the Cochrane Handbook for Systematic Reviews of Interventions (Higgins 2011); we assessed allocation (selection bias), blinding (performance bias and detection bias), incomplete outcome data (attrition bias), selective reporting (reporting bias) and other potential sources of bias. We assigned a score of high risk, unclear risk or low risk of bias, according to Higgins 2011.

\section{Measures of treatment effect}

We planned to pool the data on pain-free walking distance (PFWD) and absolute (total) walking distance (TWD) from each trial to arrive at an overall estimate of the effectiveness of pharmacological interventions. We planned to calculate the percentage change in walking distance before and after the interventions. When possible, we planned to calculate the mean difference between pentoxifylline and control groups.

\section{Unit of analysis issues}

For all included studies, the unit of randomisation was the individual participant.

\section{Dealing with missing data}

When data were not available or were missing, we contacted study authors to request missing data.

\section{Assessment of heterogeneity}

We planned to perform all analyses on an intention-to-treat basis. We planned to evaluate outcome data for appropriateness for the meta-analysis on the basis of heterogeneity by using the $\mathrm{Chi}^{2}$ test and the 12 statistic, both of which describe the percentage of variability in estimates of effect that is due to heterogeneity rather than to chance. If the $1^{2}$ value was greater than $50 \%$, we planned to evaluate data for heterogeneity. We planned to use a random-effects model for meta-analyses if no reason was found for heterogeneity. We planned to use a fixed-effect model if the 12 value was lower than $50 \%$.

\section{Assessment of reporting biases}

We planned to assess reporting bias by using funnel plots if more than 10 studies were included in the meta-analysis.

\section{Data synthesis}

We intended to perform a pooled, fixed-effect model meta-analysis of included trials with subgroup analyses using variables such as duration of treatment and dose and route of administration. However, in the light of clinical heterogeneity, we judged that a pooled meta-analysis was not appropriate.

\section{Subgroup analysis and investigation of heterogeneity}

We anticipated that trials would not be homogeneous. Therefore, we planned to perform a subgroup analysis of included trials using variables such as duration of treatment and dose and route of administration.

\section{Sensitivity analysis}

We planned to perform sensitivity analyses to evaluate the effects on meta-analysis of studies of low quality due to risk of bias, as well as studies with unclear inclusion criteria or methods.

\section{RE S U L T S}

\section{Description of studies}

\section{Results of the search}

See Figure 1 for details of the search results. For this update of the review, we identified three additional reports of studies. One study was considered to be not relevant, another was excluded (Singh 2009) and the third consisted of an abstract that correlated with a study previously listed in 'Ongoing Studies' (Schellong 2012), from which data are now available. This review update identified 24 included studies and 39 excluded studies. It should be noted that several excluded studies from the previous version of the review have been removed, as they are now considered not relevant. 
Figure 1. Study flow diagram.

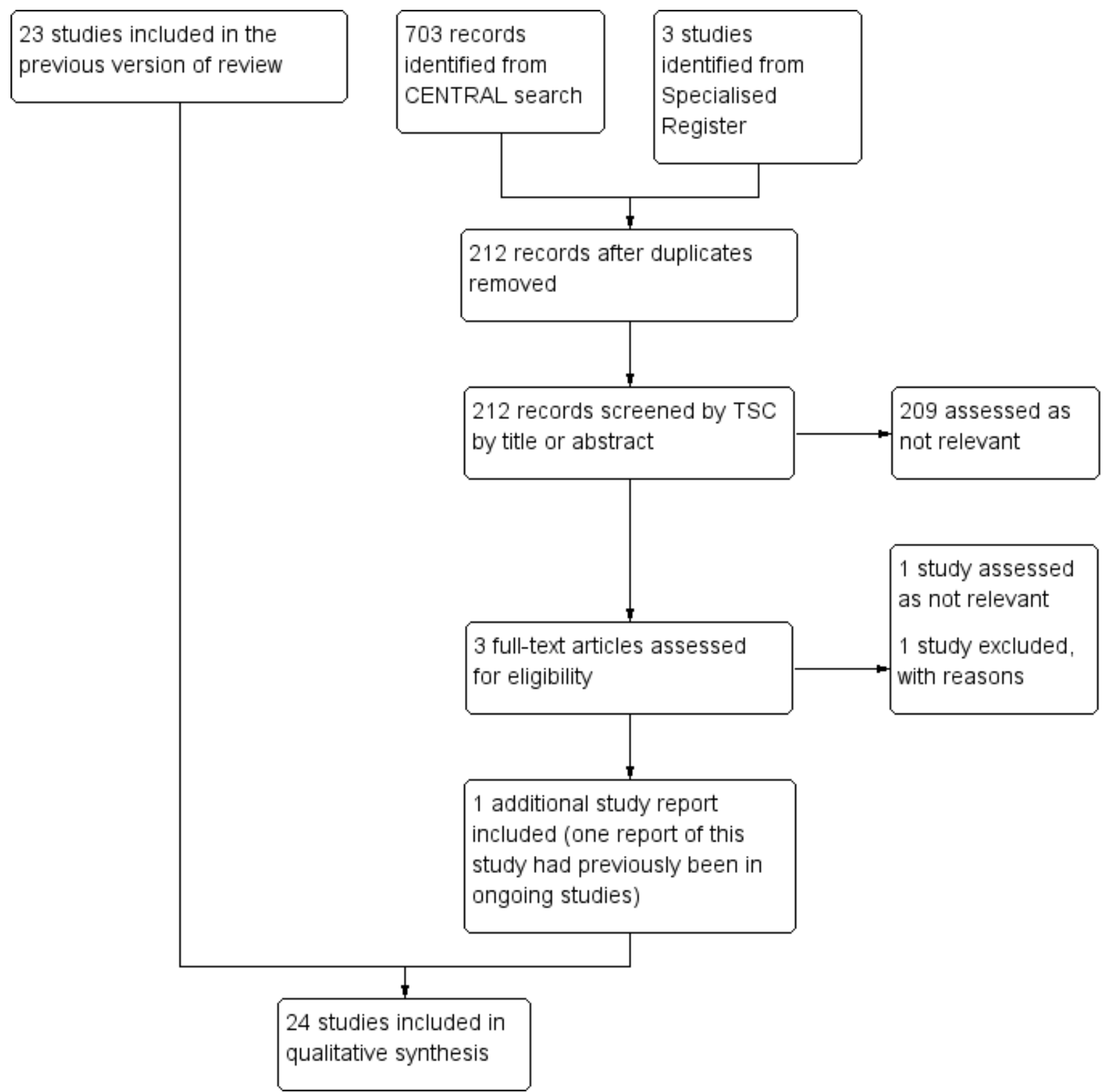

\section{Included studies}

For details of included studies, see Characteristics of included studies.

We included a total of 24 studies with 3377 participants. Fourteen studies compared pentoxifylline versus placebo alone (Belcaro 2002; Bollinger 1977; Cesarone 2002b; De Sanctis 2002a; De Sanctis 2002b; Di Perri 1983; Donaldson 1984; Ernst 1992; Gallus 1985; Kiesewetter 1988; Lindgarde 1989; Porter 1982a; Porter 1982b; Volker 1978), one versus flunarizine (Perhoniemi 1984), one versus aspirin (Ciocon 1997), one versus Gingko biloba extract (GBE) (Bohmer 1988), one versus nylidrin hydrochloride (Accetto 1982) and two versus prostaglandin E1 (PGE1) (Hepp 1992; Schellong
2012). Two studies compared pentoxifylline versus placebo and cilostazol (Dawson 2000; Lee 2001), one compared pentoxifylline versus placebo and iloprost (Creager 2008) and one compared pentoxifylline versus buflomedil and nifedipine (Chacon-Quevedo 1994).

The treadmill protocol for assessment of PFWD and TWD varied between studies. The treadmill speed most commonly used in included studies was $3 \mathrm{~km} / \mathrm{h}$, with gradients ranging from $0 \%$ (Accetto 1982) to 5\% (Bohmer 1988), 10\% (Chacon-Quevedo 1994) and 12\% (Belcaro 2002; Cesarone 2002b; De Sanctis 2002a; De Sanctis 2002b; Schellong 2012). Other studies used a treadmill speed of $3.2 \mathrm{~km} / \mathrm{h}$ - three with a gradient of $12.5 \%$ (Bollinger 1977; Lee 2001; Lindgarde 1989) and two starting at a $0 \%$ gradient and 
gradually increasing the inclination during testing (Creager 2008; Dawson 2000). One study used a treadmill speed of $3.6 \mathrm{~km} / \mathrm{h}$ at $0 \%$ gradient (Perhoniemi 1984), and two used a treadmill speed of 4 $\mathrm{km} / \mathrm{h}$ - one at a $0 \%$ gradient (Donaldson 1984) and the other at a $10 \%$ gradient (Gallus 1985). Three studies used different units of speed; Di Perri 1983 used a walking test of 120 steps per minute on a horizontal treadmill, and Porter 1982a and Porter 1982b used a speed of $1.5 \mathrm{mph}$ - both at a $7 \%$ gradient. Four studies did not provide information on the treadmill protocol used (Ernst 1992; Hepp 1992; Kiesewetter 1988; Volker 1978).

Two studies reported use of an exercise programme (Bollinger 1977; Ernst 1992). Remaining studies did not report use of an exercise programme, or reported that no specific instructions were given to participants.

\section{Excluded studies}

We excluded 39 studies because they did not meet the inclusion criteria. See the Characteristics of excluded studies table for

reasons for exclusion. In brief, 18 studies were not double-blinded (Bieron 2005; Dawson 1999; Dettori 1989; Hepp 1996; Milio 2003; Milio 2006; Panchenko 1997; Pignoli 1985; Regenthal 1991; Reilly 1987; Rodin 1998; Rodin 1998a; Scheffler 1991; Scheffler 1994; Shustov 1997; Singh 2009; Strano 2002; Triebe 1992), two included participants with critical limb ischaemia (Schubotz 1976; Thomson 1990), four included participants with Fontaine stage III and did not present results separately for the different Fontaine stages (Kellner 1976; Roekaerts 1984; Strano 1984; Tonak 1977), four were short-term studies (Farkas 1993; Rudofsky 1987; Rudofsky 1988; Rudofsky 1989), 10 described non-relevant outcomes (Ciuffetti 1991; Ehrly 1986; Ehrly 1987; Fossat 1995; Guest 2005; Incandela 2002; Luk'Janov 1995; Poggesi 1985; Tsang 1994; Wang 2003) and one used variable doses of pentoxifylline (Horowitz 1982).

\section{Risk of bias in included studies}

Risk of bias in included studies is summarised in Figure 2 and Figure 3.

\section{Figure 2. Risk of bias graph: review authors' judgements about each risk of bias item presented as percentages across all included studies.}

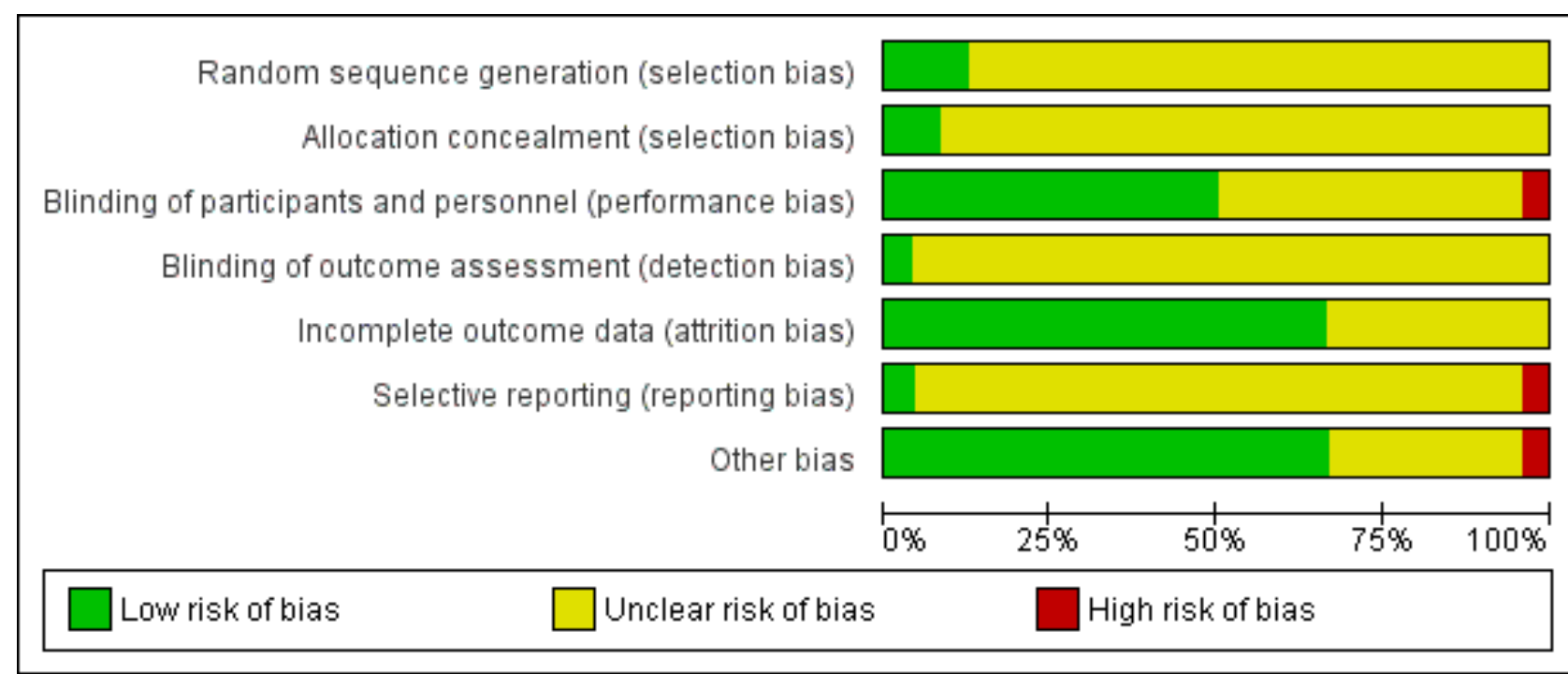

Pentoxifylline for intermittent claudication (Review) 
Figure 3. Risk of bias summary: review authors' judgements about each risk of bias item for each included study.

\begin{tabular}{|c|c|c|c|c|c|c|c|}
\hline & 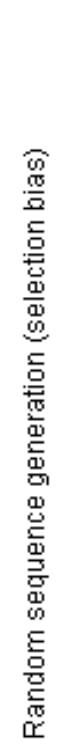 & 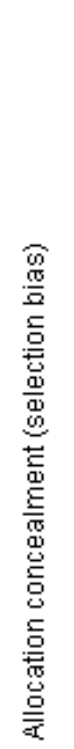 & 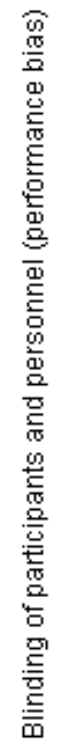 & 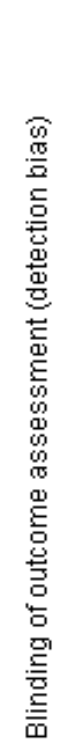 & 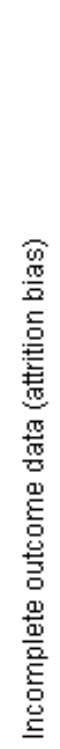 & 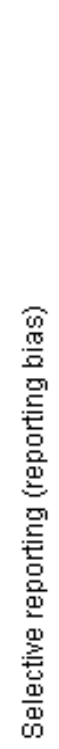 & 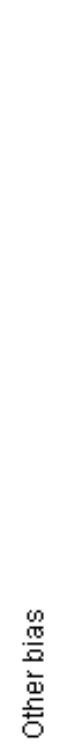 \\
\hline Accetto 1982 & $?$ & $?$ & $?$ & $?$ & $?$ & $?$ & + \\
\hline Belcaro 2002 & $?$ & $?$ & + & $?$ & + & $?$ & + \\
\hline Bohmer 1988 & $?$ & $?$ & $?$ & $?$ & $\odot$ & $?$ & $\odot$ \\
\hline Bollinger 1977 & $?$ & $?$ & + & $?$ & + & $?$ & 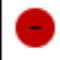 \\
\hline Cesarone 2002b & $?$ & $?$ & $?$ & $?$ & $?$ & $?$ & + \\
\hline Chacon-Quevedo 1994 & $?$ & $?$ & $?$ & $?$ & + & $?$ & $?$ \\
\hline Ciocon 1997 & $?$ & $?$ & $\Theta$ & $?$ & + & $?$ & $\odot$ \\
\hline Creager 2008 & $?$ & $?$ & + & $?$ & $?$ & $?$ & $?$ \\
\hline Dawson 2000 & 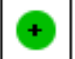 & $\odot$ & $\odot$ & $?$ & + & $?$ & $?$ \\
\hline De Sanctis 2002a & $?$ & $?$ & $?$ & $?$ & $?$ & $?$ & $?$ \\
\hline De Sanctis 2002b & $?$ & $?$ & $?$ & $?$ & $?$ & $?$ & $?$ \\
\hline Di Perri 1983 & $?$ & $?$ & + & $?$ & $?$ & $?$ & $?$ \\
\hline Donaldson 1984 & $?$ & $?$ & $?$ & $?$ & + & $?$ & + \\
\hline Ernst 1992 & $?$ & $?$ & $?$ & $?$ & + & $?$ & + \\
\hline Gallus 1985 & $?$ & $?$ & + & 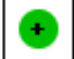 & + & $?$ & + \\
\hline Hepp 1992 & $?$ & $?$ & $?$ & $?$ & + & $?$ & + \\
\hline Kiesewetter 1988 & $?$ & $?$ & + & $?$ & $?$ & O & + \\
\hline Lee 2001 & $\odot$ & $\odot$ & $\odot$ & $?$ & + & $?$ & + \\
\hline Lindgarde 1989 & $?$ & $?$ & 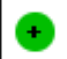 & $?$ & $?$ & $?$ & + \\
\hline Perhoniemi 1984 & $\odot$ & $?$ & $?$ & $?$ & + & $?$ & + \\
\hline
\end{tabular}


Figure 3. (Continued)

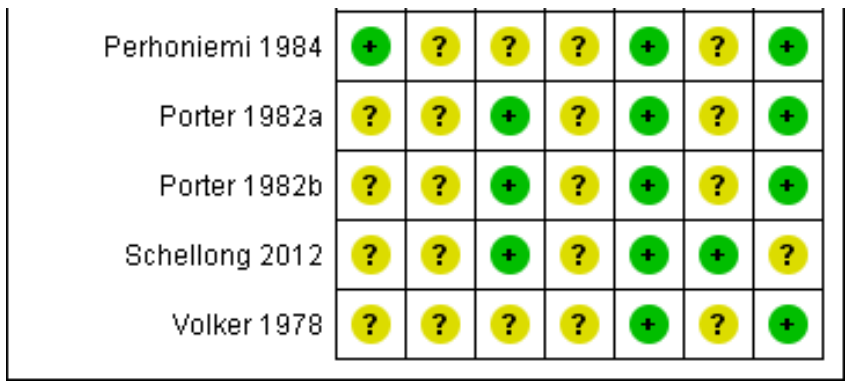

\section{Allocation}

Selection bias was deemed to involve low risk in only two studies (Dawson 2000; Lee 2001). Another study (Perhoniemi 1984) indicated low risk of bias for random sequence generation. For all other studies, available information was insufficient to permit judgement of low or high risk of bias.

\section{Blinding}

Blinding of participants and personnel was achieved in 12 studies (Belcaro 2002; Bollinger 1977; Creager 2008; Dawson 2000; Di Perri 1983; Gallus 1985; Kiesewetter 1988; Lee 2001; Lindgarde 1989; Porter 1982a; Porter 1982b; Schellong 2012), which therefore were classed as having low risk of bias. Eleven studies were classed as having unclear risk of bias (Accetto 1982; Bohmer 1988; Cesarone 2002b; Chacon-Quevedo 1994; De Sanctis 2002a; De Sanctis 2002b; Donaldson 1984; Ernst 1992; Hepp 1992; Perhoniemi 1984; Volker 1978), mainly because of insufficient reporting, and one study (Ciocon 1997) was deemed to be at high risk of bias because different treatment regimens were provided for the study medication.

For all but one study (Gallus 1985), risk of bias for blinding of outcome assessment (detection bias) was classed as unclear because of insufficient reporting. For the study by Gallus 1985, blinding of outcome assessment was deemed to present low risk of bias because study authors reported that results were withheld from investigators during the study.

\section{Incomplete outcome data}

For most included studies, no evidence suggested incomplete outcome data (Belcaro 2002; Bohmer 1988; Bollinger 1977; ChaconQuevedo 1994; Ciocon 1997; Dawson 2000; Donaldson 1984; Ernst 1992; Gallus 1985; Hepp 1992; Lee 2001; Perhoniemi 1984; Porter 1982a; Porter 1982b; Schellong 2012; Volker 1978), or information was insufficient to indicate whether outcome data were missing (Accetto 1982; Cesarone 2002b; Creager 2008; De Sanctis 2002a; De Sanctis 2002b; Di Perri 1983; Kiesewetter 1988; Lindgarde 1989).

\section{Selective reporting}

For all included studies except Kiesewetter 1988 and Schellong 2012, available information, such as a study protocol, was insufficient to permit judgement of selective reporting. Kiesewetter 1988 was judged at high risk of bias because TWD results were reported in the abstract but were not mentioned in the remainder of the paper, either as an outcome variable or as a result. Schellong 2012 was judged to have low risk, as all outcomes described in the ClinicalTrials.gov protocol were reported.

\section{Other potential sources of bias}

Most studies were deemed free of other bias (Accetto 1982; Belcaro 2002; Bohmer 1988; Cesarone 2002b; Ciocon 1997; Donaldson 1984; Ernst 1992; Gallus 1985; Hepp 1992; Kiesewetter 1988; Lee 2001; Lindgarde 1989; Perhoniemi 1984; Porter 1982a; Porter 1982b; Volker 1978). All other studies (Chacon-Quevedo 1994; Creager 2008; Dawson 2000; De Sanctis 2002a; De Sanctis 2002b; Di Perri 1983; Schellong 2012) were determined to have unclear risk of bias for a variety of reasons, such as unclear reporting (ChaconQuevedo 1994; De Sanctis 2002a; De Sanctis 2002b; Di Perri 1983) or sponsoring of the study by a pharmaceutical company (Creager 2008; Dawson 2000; Schellong 2012). One study was assigned high risk of bias because of differences in clinical baseline data between study groups (Bollinger 1977).

\section{Effects of interventions}

\section{Pentoxifylline versus placebo}

A total of 17 studies compared pentoxifylline versus placebo (Belcaro 2002; Bollinger 1977; Cesarone 2002b; De Sanctis 2002a; De Sanctis 2002b; Di Perri 1983; Donaldson 1984; Ernst 1992; Gallus 1985; Kiesewetter 1988; Lindgarde 1989; Porter 1982a; Porter 1982b; Volker 1978). Two of these studies also compared pentoxifylline versus cilostazol (Dawson 2000; Lee 2001), and one compared pentoxifylline with iloprost (Creager 2008).

\section{Pain-free walking distance (PFWD)}

A total of 11 studies (Cesarone 2002b; Creager 2008; Dawson 2000; Donaldson 1984; Ernst 1992; Gallus 1985; Kiesewetter 1988; Lindgarde 1989; Porter 1982a; Porter 1982b; Volker 1978) that compared pentoxifylline with placebo measured PFWD. The duration of these studies varied from four to 40 weeks. Most studies used a pentoxifylline dose of $1200 \mathrm{mg}$ per day. We analysed studies according to duration and dose levels. See Table 1 for details on PFWD by study. Results for PFWD are reported as percentage improvement in mean PFWD during treatment for both pentoxifylline and placebo groups. To formally compare improvement in PFWD between groups, data on both mean improvement and standard deviation of mean improvement were required. Of the 11 included studies, only one (Lindgarde 1989) presented data on standard deviation of the percentage change in PFWD; therefore, statistical analysis was performed only for this study. A pooled analysis was not conducted because data were lacking levels of heterogeneity between included studies were high with regards to multiple variables, including duration of treatment, dose of pentoxifylline, baseline walking distance and participant characteristics. 


\section{Four weeks}

At four weeks, Volker 1978 was the study of shortest duration; investigators included 50 participants (25 in each arm) and gave a dose of $1200 \mathrm{mg}$ pentoxifylline. Baseline PFWD was $331 \mathrm{~m}$ for the pentoxifylline group compared with $230 \mathrm{~m}$ for the placebo group. At the end of the study, mean PFWD for participants who received pentoxifylline improved by $40.3 \%$ compared with $26.0 \%$ for those given placebo, for a difference of $14.3 \%$ in favour of pentoxifylline.

\section{Eight weeks}

Three studies had a duration of eight weeks (Donaldson 1984; Gallus 1985; Kiesewetter 1988). One study (Donaldson 1984) used $600 \mathrm{mg}$ of pentoxifylline, and the other two used $1200 \mathrm{mg}$. Gallus 1985 was a cross-over study consisting of two periods of eight weeks.

Donaldson 1984 included 40 participants in each group. The increase in mean PFWD in the pentoxifylline group, from $108.2 \mathrm{~m}$ to $119.3 \mathrm{~m}$ (10.3\%), was $22.6 \%$ less than in the placebo group, from $97.1 \mathrm{~m}$ to $129 \mathrm{~m}(32.9 \%)$.

Gallus 1985 performed a cross-over study. Fifty participants were recruited, but only 38 finished the study and were included in the analysis (19 participants in each group). Study authors reported no statistically significant improvement in PFWD for pentoxifylline compared with placebo but did not present the results of significance tests. In the first phase of the study (eight weeks), PFWD in the pentoxifylline group improved by $7.7 \%$ more than in the placebo group (76.0\% vs $68.3 \%)$. After the second portion of the study, participants treated with pentoxifylline in phase 1 and placebo in phase 2 showed a decrease of $9.4 \%$ in PFWD after cross-over. Those treated with placebo in phase 1 and pentoxifylline in phase 2 improved by $10.4 \%$ after cross-over.

Kiesewetter 1988 compared $1200 \mathrm{mg}$ of pentoxifylline versus placebo over eight weeks in a study with 40 participants. Results showed that PFWD in the pentoxifylline group improved by $44 \mathrm{~m}$ $(43.6 \%)$ compared with $3 \mathrm{~m}$ (3.1\%) in the placebo group. Authors of this paper did not present data on baseline walking distance for the two groups.

\section{Twelve weeks}

One study, which lasted 12 weeks (Ernst 1992), used 1200 mg pentoxifylline daily and included 40 participants (20 in each arm). Both groups of participants exercised regularly for one hour twice a week. Study authors stated that both groups showed significant improvement in walking distance, although they did not present the results of statistical tests. The pentoxifylline group improved by $152.8 \%$ ( $144 \mathrm{~m}$ to $364 \mathrm{~m}$ ) and the placebo group by $186.6 \%$ (134 m to $384 \mathrm{~m}$ ), for a difference of $33.8 \%$ in favour of placebo.

\section{Twenty-four weeks}

All studies with a duration of 24 to 26 weeks (six months) used 1200 mg of pentoxifylline (Creager 2008; Dawson 2000; Lindgarde 1989; Porter 1982a; Porter 1982b).

In a large multi-centre study, Creager 2008 compared pentoxifylline versus placebo (and vs various doses of iloprost) over six months. In this study, 430 participants were randomly assigned to five groups: iloprost $50 \mu \mathrm{g}$ (87 participants), iloprost $100 \mu \mathrm{g}$ (86 participants), iloprost 150 Mg (87 participants), pentoxifylline $1200 \mathrm{mg}$ (86 participants) and placebo (84 participants). Only 214 participants $(\approx$
$50 \%$ ) completed the entire six months of the study. Three hundred seventy participants were included in what was called an intentionto-treat analysis on the basis that they had received at least one dose of the study drug and had undergone at least one followup test, that is, within two to four weeks. Walking distance in the pentoxifylline group improved by $34.3 \%$ from a baseline PFWD of $118 \mathrm{~m}$ compared with a $21.2 \%$ improvement in the placebo group from a baseline PFWD of $120 \mathrm{~m}$. Overall, pentoxifylline improved PFWD by $13.1 \%$ more than placebo, but this difference could not be analysed statistically because data were insufficient. Study authors reported that after one month, the difference between groups was statistically significant, but $P$ values for significance results were not provided.

Dawson 2000 included 232 participants in the pentoxifylline group and 239 in the placebo group. The pentoxifylline group improved by $12.8 \%$ more than the placebo group $(60.3 \%$ vs $47.5 \%)$.

Lindgarde 1989 included 76 participants in the pentoxifylline group and 74 in the placebo group. Results showed a net improvement for pentoxifylline of $20 \%$ (95\% confidence interval (CI) 16.3 to 23.7 ) over placebo ( $80 \%$ vs $60 \%)$. This improvement was statistically significant $(P$ value $<0.0001)$.

Porter 1982a was a relatively large study with no intentionto-treat analysis. Gillings 1987 performed an intention-to-treat analysis on data from the Porter 1982a study. Initially, Porter 1982a double-blinded 128 participants (including one who was randomly assigned twice) but included only 82 participants in the analysis (pentoxifylline 42, placebo 40); remaining participants were withdrawn from the study because of side effects and loss to follow-up. In the initial analysis, PFWD distance improved in the pentoxifylline group from $111 \mathrm{~m}$ to $195 \mathrm{~m}(75.7 \%)$ and in the placebo group from $117 \mathrm{~m}$ to $180 \mathrm{~m}(53.8 \%)$, yielding a statistically significant difference of $21.9 \%(P$ value $=0.18)$ in favour of pentoxifylline. Gillings 1987 included 124 participants who had follow-up data (63 in the pentoxifylline group and 61 in the placebo group). In this intention-to-treat analysis, PFWD improved in the pentoxifylline group by $47 \%$ and in the placebo group by $26 \%$ (difference of $21 \%$ in favour of pentoxifylline). The authors of this paper did not present data on end-of-trial PFWD.

Another, smaller study by Porter et al. (Porter 1982b) consisted of 22 participants ( 11 in each arm). In this study, PFWD in the pentoxifylline group improved by $73.9 \%$ more than in the placebo group ( $108.8 \%$ vs $34.9 \%$, respectively).

\section{Forty weeks}

Cesarone 2002 used $1600 \mathrm{mg}$ of pentoxifylline daily for 40 weeks. The pentoxifylline group consisted of 88 participants, and the placebo group 90 participants. Total PFWD in the pentoxifylline group improved from $43 \mathrm{~m}$ to $166 \mathrm{~m}$ (286\%), and in the placebo group from $42 \mathrm{~m}$ to $155 \mathrm{~m}$ (269\%), for a small difference of $17 \%$ in favour of pentoxifylline.

\section{Total walking distance (TWD)}

A total of 14 studies comparing pentoxifylline with placebo (Belcaro 2002; Bollinger 1977; Cesarone 2002b; Creager 2008; Dawson 2000; De Sanctis 2002a; De Sanctis 2002b; Di Perri 1983; Ernst 1992; Gallus 1985; Lee 2001; Lindgarde 1989; Porter 1982a; Porter 1982b) assessed TWD. The duration of these studies ranged from eight weeks to 52 weeks. See Table 2 for details on TWD by study. As was 
done for PFWD, TWD was reported as percentage change in mean TWD from baseline to end of study for pentoxifylline and placebo groups separately, and as the difference in percentage change between groups. Again, data on mean change in TWD and standard deviation of the change were required to compare improvement in TWD between groups. In all 14 included studies, trial authors failed to report the standard deviation of the percentage change in mean TWD, so a statistical analysis could not be performed. Meta-analysis of TWD results for pentoxifylline compared with placebo was not performed for reasons similar to those described for PFWD results.

\section{Eight weeks}

Four studies had a duration of eight weeks. One study used 600 mg (Bollinger 1977), one $800 \mathrm{mg}$ (Lee 2001) and two $1200 \mathrm{mg}$ pentoxifylline (Di Perri 1983; Gallus 1985).

In Bollinger 1977, the sample size was 19 participants (10 pentoxifylline and nine placebo) with a dose of $600 \mathrm{mg}$ of pentoxifylline. The quality of the study was poor; initially 26 participants were included, but results for only 19 were included in the analysis. No intention-to-treat analysis was performed. The two groups varied in terms of duration of claudication and extent of disease. Participants in the pentoxifylline group had more unilateral disease, and more bilateral and extensive disease was noted in the placebo group. All participants in this study were advised to stop smoking and to walk daily for at least one hour. Investigators reported improvement with pentoxifylline over placebo of $155.9 \%$ (208.4\% vs $52.5 \%)$.

Lee and colleagues published two reports on the same study (Lee 2001; Lee 2001a). Only a very slight difference was apparent between reports in that the sample size was larger by two participants in the later report (17 in the pentoxifylline group, 16 in the placebo group and 17 in the cilostazol group). Results from Lee 2001 are included in both reports. TWD improved in the pentoxifylline group from $114 \mathrm{~m}$ to $147 \mathrm{~m}$ (28.9\%) compared with $116 \mathrm{~m}$ to $121 \mathrm{~m}(4.3 \%)$ in the placebo group, for an overall difference of $24.6 \%$ in favour of pentoxifylline.

Di Perri 1983 examined 1200 mg of pentoxifylline in 24 participants using a cross-over design (12 participants in each group over two periods of eight weeks). A $61 \%$ increase in TWD was described for the pentoxifylline group compared with 3.5\% for the placebo group after the first period. This was confirmed after the cross-over, when the pentoxifylline group again increased by $61 \%$ compared with an increase of $1.9 \%$ in the placebo group.

In Gallus 1985, also a cross-over study, TWD showed a pattern similar to PFWD. After the first phase of the study, TWD improved by $33.3 \%$ in the pentoxifylline group compared with $13.5 \%$ in the placebo group (difference of $19.8 \%$ in favour of pentoxifylline). After the cross-over phase, participants who were treated with pentoxifylline in phase 1 and placebo in phase 2 improved by just $1.88 \%$ over those treated with placebo before pentoxifylline.

\section{Twelve weeks}

One study reported findings at 12 weeks (Ernst 1992). Both groups of participants also received regular exercise, for one hour twice a week. TWD in the pentoxifylline group ( $1200 \mathrm{mg}$ daily) improved from $166 \mathrm{~m}$ to $504 \mathrm{~m}(203.6 \%)$ compared with improvement in the placebo group from $151 \mathrm{~m}$ to $420 \mathrm{~m}(178.1 \%)$, yielding a difference of $25.5 \%$ in favour of pentoxifylline.

\section{Twenty-four to twenty-six weeks}

Six studies (Belcaro 2002; Creager 2008; Dawson 2000; Lindgarde 1989; Porter 1982a; Porter 1982b) had a duration of 24 to 26 weeks (six months). Apart from Belcaro 2002, which used a dose of 1600 $\mathrm{mg}$, and Creager 2008, which used $400 \mathrm{mg}$, studies used $1200 \mathrm{mg}$ of pentoxifylline.

Belcaro 2002 compared $1600 \mathrm{mg}$ daily of pentoxifylline versus placebo. TWD improved in the pentoxifylline group from $56 \mathrm{~m}$ to $161 \mathrm{~m}(187.5 \%)$, and TWD in the placebo group improved from 59 $\mathrm{m}$ to $103 \mathrm{~m}(74.6 \%)$, showing a difference of $112.9 \%$ in favour of pentoxifylline.

Creager 2008 presented baseline TWD and percentage improvement rather than TWD at the end of the study. The pentoxifylline versus placebo result showed significant improvement for pentoxifylline of 13.9\% (from baseline TWD of 316 $\pm 191 \mathrm{~m}$ ) compared with placebo, which resulted in improvement of only 3.3\% (from baseline TWD of $292 \pm 161 \mathrm{~m}$ ), for a difference of $10.6 \%$ in favour of pentoxifylline.

Dawson 2000 did not show significant improvement in TWD for pentoxifylline over placebo ( $29.4 \%$ vs $28.2 \%)$.

In Lindgarde 1989, TWD improved by $50 \%$ in the pentoxifylline group compared with $29 \%$ in the placebo group, for a difference of $21 \%$ in favour of pentoxifylline. Data on TWD at the end of the study were not presented, and improvement in TWD between groups could not be analysed statistically.

In the original analysis of Porter 1982a, TWD improved from 172 $\mathrm{m}$ to $268 \mathrm{~m}(55.8 \%)$ in the pentoxifylline group and from $181 \mathrm{~m}$ to $250 \mathrm{~m}(38.1 \%)$ in the placebo group, for a net difference of $17.7 \%$ in favour of pentoxifylline. In Gillings 1987 (the intention-to-treat analysis of the Porter 1982a study) and Reich 1984 (a publication based on the Porter 1982a study), TWD in the pentoxifylline group improved by $32 \%$ compared with $20 \%$ in the placebo group (difference of $12 \%$ in favour of pentoxifylline). Data on TWD at the end of this study were not presented.

In Porter 1982b, the net improvement in TWD observed in the pentoxifylline group over the placebo group was $66.5 \%$ ( $P$ value $=0.002$ ). TWD in the pentoxifylline group improved by $69.4 \%$ compared with just $2.9 \%$ in the placebo group.

\section{Forty weeks}

Investigators in one study with a duration of 40 weeks gave 1600 mg of pentoxifylline daily (Cesarone 2002b). This study included 88 participants in the pentoxifylline group and 90 in the placebo group. Very large improvement in TWD of $229.9 \%$ was seen in the pentoxifylline group (from $87 \pm 11 \mathrm{~m}$ to $287 \pm 340 \mathrm{~m}$ ) compared with $83.7 \%$ (from $98 \pm 14 \mathrm{~m}$ to $180 \pm 120 \mathrm{~m}$ ) in the placebo group, for a net difference of $146.2 \%$.

\section{Fifty-two weeks}

Two studies were reported by De Sanctis in 2002 (De Sanctis 2002a; De Sanctis 2002b). The former study looked at participants with a baseline TWD between $50 \mathrm{~m}$ and $200 \mathrm{~m}$, and the latter study examined participants with a greater baseline TWD (> $500 \mathrm{~m}$ ). Investigators in both studies administered $1800 \mathrm{mg}$ of pentoxifylline daily. 
In De Sanctis 2002a, each group consisted of 60 participants initially, but only 56 of those in the pentoxifylline group and 45 in the placebo group completed the study. In this study, baseline walking distance was short, and the effect of pentoxifylline was more prominent. The pentoxifylline group improved by $304.5 \%$ (66 $\pm 13 \mathrm{~m}$ to $267 \pm 38 \mathrm{~m}$ ), and the placebo group by $180.6 \%$ ( $67 \pm 11 \mathrm{~m}$ to $188 \pm 19 \mathrm{~m}$ ), for a net difference of $123.9 \%$ in favour of pentoxifylline.

De Sanctis 2002b included 98 participants in the pentoxifylline group (75 of whom completed the study) and 96 in the placebo group ( 60 of whom completed the study). Significant improvement in TWD from baseline was reported in both groups, and the pentoxifylline group improved by $39.1 \%$ more than the placebo group. In the pentoxifylline group, TWD increased by $70.2 \%$ (554 \pm $66 \mathrm{~m}$ to $943 \pm 78 \mathrm{~m}$ ) versus $31.1 \%$ ( $576 \pm 71 \mathrm{~m}$ to $755 \pm 67 \mathrm{~m})$ in the placebo group.

\section{Ankle-brachial pressure index $(A B I)$}

Five studies comparing pentoxifylline versus placebo (Bollinger 1977; Dawson 2000; Donaldson 1984; Gallus 1985; Lee 2001) measured ABI. Three of these looked only at pre-exercise or resting ABI (Bollinger 1977; Dawson 2000; Lee 2001), and two looked at both pre-exercise and post-exercise ABI (Donaldson 1984; Gallus 1985). Authors of all five studies presented mean ABI at baseline and at end of treatment for both pentoxifylline and placebo groups. However, as the standard deviation for the change in $A B I$ was not presented in any of the studies, statistical analysis could not be conducted to compare improvement in $\mathrm{ABI}$. Furthermore, none of the five studies reported results of their own statistical tests. $A B$ results were not amenable to meta-analysis because of lack of data, differences in $\mathrm{ABI}$ measurements and differences in pentoxifylline doses and study duration.

In Bollinger 1977, pre-exercise ABI improved from 0.57 to 0.64 in the pentoxifylline group, and in the placebo group it dropped from 0.62 to 0.59 on the basis of measurements from the posterior tibial artery. Trialists stated that although a tendency toward better results was evident in the pentoxifylline group, results were not statistically significant.

Dawson 2000 reported that $A B I$ increased in the pentoxifylline group from $0.66 \pm 0.21$ at baseline to $0.71 \pm 0.24$ at 24 weeks. In the placebo group, $A B I$ did not improve $(0.68 \pm 0.42$ at baseline, $0.67 \pm$ 0.19 at 24 weeks). Study authors reported that improvement in $A B I$ in the pentoxifylline group was not significantly different from that in the placebo group but did not present the level of significance.

In Lee 2001, mean pre-exercise $A B I$ improved in the pentoxifylline group from $0.66 \pm 0.13$ to $0.7 \pm 0.14$, and in the placebo group from $0.69 \pm 0.12$ to $0.71 \pm 0.13$. Study authors reported no significant changes in $\mathrm{ABI}$ across all groups (including cilostazol).

In Donaldson 1984, no difference in $\mathrm{ABI}$ was reported in the pentoxifylline group nor in the placebo group before and after exercise. In the pentoxifylline group, pre-exercise $A B I$ remained the same at $0.52 \pm 0.26$ before and after treatment. Post-exercise $\mathrm{ABI}$ dropped from $0.3 \pm 0.27$ before treatment to $0.27 \pm 0.25$ after treatment. In the placebo group, pre-exercise $A B I$ improved from $0.52 \pm 0.25$ to $0.57 \pm 0.24$, and in the treatment group from $0.32 \pm$ 0.26 to $0.34 \pm 0.30$. Study authors stated that none of these results were statistically significant ( $P$ values not presented).
Gallus 1985 reported no differences in the pentoxifylline group nor in the placebo group before and after exercise at the end of a crossover study. In the pentoxifylline group, pre-exercise $A B I$ improved from $0.59 \pm 0.14$ before treatment to $0.61 \pm 0.16$ after treatment; and post-exercise ABI dropped from 0.13 (range 0.03 to 0.60 ) before treatment to 0.10 (range 0.02 to 0.55 ) after treatment. In the placebo group, pre-exercise $A B I$ remained similar at $0.59 \pm 0.14$ before and $0.59 \pm 0.16$ after treatment. Post-exercise $A B I$ increased slightly, from 0.13 (range 0.03 to 0.60 ) before treatment to 0.14 (range 0.03 to 0.63 ) after treatment. None of these results were reported as statistically significant, and the level of significance used was not reported in the paper.

\section{Quality of life}

Three studies comparing pentoxifylline versus placebo reported on quality of life (Creager 2008; Dawson 2000; Volker 1978).

Both Dawson 2000 and Creager 2008 reported no differences between treatment groups in Short Form 36 (SF36) scores. Scores on the walking impairment questionnaire (WIQ) - a measure of degree of handicap caused by the disease - were similar between pentoxifylline and placebo groups in the Dawson 2000 study. Creager 2008 reported that stair climbing was the only domain of the WIQ questionnaire that significantly improved when the pentoxifylline group and the placebo group were compared ( $9 \%$ increase in score; $\mathrm{P}$ value $=0.04$ ).

Volker 1978 reported that in the pentoxifylline group, 18 participants reported improvement and seven reported no improvement. Six participants in the placebo group showed improvement, 18 showed no improvement and one showed a decline. Differences between treatment groups were statistically significant $(P$ value $<0.01)$.

\section{Side effects}

Nine studies comparing pentoxifylline versus placebo reported on side effects (Belcaro 2002; Cesarone 2002b; Creager 2008; Dawson 2000; De Sanctis 2002b; Lee 2001; Porter 1982a; Porter 1982b; Volker 1978).

Belcaro 2002, Cesarone 2002b, De Sanctis 2002b and Lee 2001 reported that no side effects or serious side effects were observed.

Creager 2008 reported that the most common adverse events observed in the pentoxifylline group were headache at 19\%, pain in extremity at $14 \%$ and dyspepsia at $13 \%$, compared with $16 \%$, $7 \%$ and $5 \%$, respectively, in the placebo group. The frequency of premature discontinuation of pentoxifylline was similar to that of placebo. Serious adverse events were reported in $14 \%$ of the pentoxifylline group compared with $17 \%$ of the placebo group.

Dawson 2000 reported that the withdrawal rate from placebo was $16 \%(38 / 239)$ compared with $26 \%$ (60/232) from pentoxifylline. Most of the commonly reported side effects, such as headache and diarrhoea, were similar between pentoxifylline and placebo groups, except for pharyngitis, which was reported by $14 \%$ in the pentoxifylline group and $7 \%$ in the placebo group.

Porter 1982a reported that 55\% (37/67) of participants in the pentoxifylline group and $39 \%(24 / 61)$ of those in the placebo group reported side effects. Side effects reported were 
mainly gastrointestinal complaints; the most commonly reported complaint was nausea.

Porter 1982b reported that no participants discontinued as a result of drug-related side effects, which were minimal in the two treatment groups. According to trialists, the only statistically significant ( $P$ value not presented) side effect was nausea, which was reported by seven pentoxifylline participants.

Volker 1978 reported similar numbers of side effects in the two treatment groups. In the pentoxifylline group (25 participants), two participants reported headaches, two dizziness, two stomach pains and two itching, and in the placebo group (25 participants), two participants reported headaches, two dizziness and three stomach pains.

\section{Pentoxifylline versus flunarizine}

Perhoniemi 1984 compared 1200 mg of pentoxifylline daily versus $15 \mathrm{mg}$ of flunarizine daily over six months (three-month crossover design). Seventeen participants started on flunarizine, and 14 started on pentoxifylline.

\section{Pain-free walking distance}

In Perhoniemi 1984, PFWD increased for both pentoxifylline and flunarizine groups ( $P$ value $<0.01$ ) when compared with baseline, but no statistically significant difference was found between pentoxifylline and flunarizine groups (Table 3).

\section{Total walking distance}

In Perhoniemi 1984, statistically significant improvement in TWD was noted in both groups (43\% for pentoxifylline and $18 \%$ for flunarizine), but no statistically significant differences were observed between groups (Table 4).

\section{Ankle-brachial pressure index}

No difference in $A B I$ was found by Perhoniemi 1984 between baseline measurements $(0.63 \pm 0.20)$ and measurements after treatment (pentoxifylline $0.63 \pm 0.19$; flunarizine $0.62 \pm 0.20$ ), nor between treatment groups.

\section{Quality of life}

Perhoniemi 1984 did not measure quality of life.

\section{Side effects}

In Perhoniemi 1984, 32 participants reported side effects (tiredness, diarrhoea, gastrointestinal symptoms, sweating, itching and allergic reactions), but no statistically significant differences were noted between flunarizine and pentoxifylline groups. One participant in the pentoxifylline group discontinued the study because of gastrointestinal symptoms.

\section{Pentoxifylline versus aspirin}

Ciocon 1997 compared $325 \mathrm{mg}$ of aspirin versus $1200 \mathrm{mg}$ of pentoxifylline over six weeks. Each group included 45 participants.

\section{Pain-free walking distance}

Ciocon 1997 did not measure PFWD.

\section{Total walking distance}

Baseline TWD was one mile for the pentoxifylline group. This increased to two miles after the treatment period, showing improvement of $100 \%$. The aspirin group showed improvement of $50 \%$, from 0.8 miles to 1.2 miles. Study authors reported that $50 \%$ improvement in TWD after treatment with pentoxifylline versus placebo was statistically significant $(P$ value $<0.05)$ (Table 4).

\section{Ankle-brachial pressure index}

$A B I$ testing showed very slight improvement in the pentoxifylline group, from $0.6 \pm 0.1$ to $0.7 \pm 0.2$, and in the aspirin group, $A B I$ remained similar ( $0.6 \pm 0.3$ at baseline, $0.6 \pm 0.5$ after treatment).

\section{Quality of life}

Ciocon 1997 did not measure quality of life.

\section{Side effects}

Ciocon 1997 did not measure side effects.

\section{Pentoxifylline versus Ginkgo biloba extract (GBE)}

Bohmer 1988 compared pentoxifylline with GBE. A total of 27 participants were included: 13 received $1200 \mathrm{mg}$ of pentoxifylline daily, and 14 received $160 \mathrm{mg}$ of GBE, over 24 weeks.

\section{Pain-free walking distance}

In Bohmer 1988, PFWD significantly improved in both groups after treatment, but no statistically significant difference was observed between treatment groups. PFWD increased in the pentoxifylline group from $80.1 \mathrm{~m}$ to $325.6 \mathrm{~m}$ ( $P$ value $<0.05$ ), and in the GBE group from $94.6 \mathrm{~m}$ to $327.5 \mathrm{~m}$ ( $P$ value $<0.01$ ) (Table 3). A statistically significant difference between treatment groups was not detected, according to Bohmer 1988.

\section{Total walking distance}

TWD significantly improved in both groups after treatment, but no statistically significant difference was observed between treatment groups. TWD increased in the pentoxifylline group from $189.5 \mathrm{~m}$ to $472.3 \mathrm{~m}$ ( $P$ value $<0.01$ ), and in the GBE group from $203 \mathrm{~m}$ to 436.5 $\mathrm{m}$ ( $P$ value $<0.01$ ) (Table 4). A statistically significant difference between treatment groups was not detected, according to Bohmer 1988.

\section{Ankle-brachial pressure index}

Bohmer 1988 reported that $A B I$ increased slightly in both treatment groups but did not present the data.

\section{Quality of life}

Bohmer 1988 did not measure quality of life.

\section{Side effects}

Bohmer 1988 did not measure side effects.

\section{Pentoxifylline versus nylidrin hydrochloride}

Accetto 1982 compared $400 \mathrm{mg}$ of pentoxifylline daily versus $3 \mathrm{mg}$ of nylidrin hydrochloride daily, over eight weeks.

\section{Pain-free walking distance}

Accetto 1982 did not measure PFWD. 


\section{Total walking distance}

Compared with baseline, TWD increased in the pentoxifylline group from $132.6 \mathrm{~m}$ to $193.4 \mathrm{~m}(46.7 \%)$, and in the nylidrin group from $163.4 \mathrm{~m}$ to $168.9 \mathrm{~m}(1 \%)$ ( $\mathrm{P}$ value $=0.006)$. Study authors also expressed TWD in seconds, with the pentoxifylline group improving from 160 seconds at baseline to 240 seconds after treatment. TWD in the nylidrin group at baseline was 197 seconds, and after treatment 220 seconds. Improvement in walking distance was observed in 17 of 23 in the pentoxifylline group and in 11 of 24 in the nylidrin hydrochloride $(\mathrm{HCl}$ ) group (Table 4). Accetto 1982 reported that at the end of treatment, a significant difference favoured pentoxifylline $(P$ value $=0.006)$.

\section{Ankle-brachial pressure index}

Accetto 1982 did not measure ABI.

\section{Quality of life}

Accetto 1982 did not measure quality of life.

\section{Side effects}

Accetto 1982 reported that 6 of 23 pentoxifylline participants and 3 of 24 nylidrin $\mathrm{HCl}$ participants reported side effects. Most of these were gastrointestinal in nature, and all were transient and of mild severity.

\section{Pentoxifylline versus prostaglandin E1 (PGE1)}

Two studies compared pentoxifylline versus prostaglandin E1 (Hepp 1992; Schellong 2012).

Hepp 1992 compared intravenous pentoxifylline (400 mg) versus intravenous PGE1 (80 mg) over four weeks. Schellong 2012 compared pentoxifylline $(600 \mathrm{mg}$ twice daily for a total of 1200 $\mathrm{mg})$ versus intravenous PGE1 $(20 \mu \mathrm{g}$ alprostadil) over a total of eight weeks, which was broken down into two four-week treatment periods; four weeks of PGE1 injections given daily were followed by four weeks of bi-weekly injections. It should be noted that for the Schellong 2012 study, all data were retrieved from the ClinicalTrials.gov website, which offered no actual walking distances - only ratios - and no findings of statistical analysis. It is hoped that future publications planned for this study will provide additional information on data and collection methods.

\section{Pain-free walking distance}

Median PFWD increased in the pentoxifylline group from $72 \mathrm{~m}$ to $133 \mathrm{~m}(85 \%)$ compared with an increase in the PGE1 group from 80 $\mathrm{m}$ to $175 \mathrm{~m}$ (119\%) (Table 3). According to Hepp 1992, the difference between treatments was statistically significant $(P$ value $<0.001)$.

Results from Schellong 2012 were presented as ratios for PFWD at the specified time point compared with baseline PFWD with standard deviations. After the first four-week treatment period (daily PGE1), the ratio of PFWD compared with baseline for pentoxifylline-treated participants was $1.58 \pm 2.59$, and for PGE1treated participants $1.58 \pm 1.92$. After the second four-week treatment period (bi-weekly PGE1), the PFWD ratio was $1.98 \pm 3.61$ compared with baseline for pentoxifylline-treated participants, and $2.60 \pm 12.22$ for those treated with PGE1. After six months of posttreatment follow-up, the ratio was $2.36 \pm 2.69$ for pentoxifylline, and $2.27 \pm 3.00$ for PGE1.

\section{Total walking distance}

Median TWD increased in the pentoxifylline group from $115 \mathrm{~m}$ to 190 $\mathrm{m}(65 \%)$ and in the PGE1 group from $129 \mathrm{~m}$ to $230 \mathrm{~m}(78 \%)$ (Table 4). According to Hepp 1992, the difference between treatments was statistically significant $(P$ value $<0.01)$.

As with PFWD, Schellong 2012 reported TWD as a ratio of the time point measurement compared with baseline. Following the first four-week treatment period (daily PGE1), the ratio of TWD compared with baseline for pentoxifylline-treated participants was $1.43 \pm 1.34$, and for PGE1-treated participants $1.39 \pm 0.53$. After the second four-week treatment period (bi-weekly PGE1), TWD ratio compared with baseline was $1.76 \pm 1.78$ for pentoxifylline-treated participants and $1.64 \pm 0.86$ for those treated with PGE1. Six months after treatment, the ratio for pentoxifylline was $1.99 \pm 1.61$, and for PGE1 $1.89 \pm 1.40$.

\section{Ankle-brachial pressure index}

Hepp 1992 and Schellong 2012 did not measure ABI.

\section{Quality of life}

Hepp 1992 did not measure quality of life.

Schellong 2012 measured mean changes in quality of life using the Peripheral Arterial Occlusive Disease 86 quality of life questionnaire (PAVK 86) and reported changes from baseline to the end of the six-month follow-up period for eight domains, along with standard deviations. A change in the pain domain of $-0.41 \pm 0.58$ was noted for the pentoxifylline group, and $-0.28 \pm 0.57$ for the PGE1 group. Functional status showed a change of $-0.35 \pm 0.57$ for the pentoxifylline group, and $-0.26 \pm 0.58$ for the PGE1 group. A change in the anxiety domain of $-0.22 \pm 0.66$ was reported for the pentoxifylline group, and $-0.20 \pm 0.64$ for the PGE1 group. For the pentoxifylline group, a change of $-0.12 \pm 0.53$ in mood and a smaller change of $-0.04 \pm 0.45$ in social life were observed, and the PGE1 group showed changes of $-0.06 \pm 0.48$ and $-0.09 \pm 0.43$, respectively. For expectation of treatment, investigators reported an increase of $0.11 \pm 0.49$ for the pentoxifylline group and $0.07 \pm 0.51$ for the PGE1 group. State of general health during the last week showed a change of $-0.48 \pm 1.98$ for the pentoxifylline group, with change in quality of life of $-0.39 \pm 2.20$ during the last week, and the PGE1 group recorded mean changes of $-0.43 \pm 1.83$ and $-0.36 \pm 2.09$, respectively.

\section{Side effects}

Hepp 1992 reported that one PGE1 participant experienced nausea, and two others discontinued study medication for reasons unrelated to the medication. In total, six participants discontinued pentoxifylline treatment early because of nausea. In both treatment groups, no cardiovascular side effects were observed.

Schellong 2012 reported 17 total serious adverse events in 28 $(5.96 \%)$ participants in the pentoxifylline group and 19 among $276(6.88 \%)$ participants in the PGE1 group, which included, but were not limited to, coronary artery disease, angina, carotid artery stenosis and peripheral arterial occlusive disease (although it is noted that many of these are not necessarily events, but rather co-morbidities with events during the trial). Other adverse events were reported in 55 of $285(19.30 \%)$ participants in the pentoxifylline group and in 60 of $276(21.74 \%)$ in the PGE1 group; 
these included, but were not limited to, vertigo, gastrointestinal symptoms, peripheral oedema and hyperlipidaemia.

\section{Pentoxifylline versus cilostazol}

Two studies compared pentoxifylline versus cilostazol (Dawson 2000; Lee 2001).

\section{Pain-free walking distance}

One study (Dawson 2000) examined PFWD. This study compared 232 participants who received $1200 \mathrm{mg}$ of pentoxifylline versus 227 who received $200 \mathrm{mg}$ of cilostazol daily over 24 weeks. PFWD in the cilostazol group improved by $75.8 \%(124 \pm 81 \mathrm{~m}$ to $218 \pm 149 \mathrm{~m})$ compared with $60.3 \%$ in the pentoxifylline group $(126 \pm 79 \mathrm{~m}$ to 202 $\pm 139 \mathrm{~m}$ ), with a net difference of $15.5 \%$. As standard deviations were not presented in the paper, it was not possible to compare improvement in PFWD between treatment groups (Table 3).

\section{Total walking distance}

Both studies examined TWD (Table 4). In Dawson 2000, TWD improved in the cilostazol group by $45.2 \%$ ( $241 \pm 123 \mathrm{~m}$ to $350 \pm$ $209 \mathrm{~m}$ ) compared with the pentoxifylline group, which improved by $29.4 \%$ ( $238 \pm 119 \mathrm{~m}$ to $308 \pm 183 \mathrm{~m})$, with a net difference of $15.8 \%$. Statistical analysis comparing improvement in TWD between treatment groups could not be performed because data on standard deviations were insufficient.

Lee 2001 compared 17 participants who received $800 \mathrm{mg}$ of pentoxifylline daily versus another 17 who received $200 \mathrm{mg}$ of cilostazol. The pentoxifylline group improved by $29 \%$ (114 $\pm 51 \mathrm{~m}$ to $147 \pm 81 \mathrm{~m}$ ) versus $30 \%$ improvement in the cilostazol group $(111 \pm 30 \mathrm{~m}$ to $145 \pm 53 \mathrm{~m})$. Differences in improvement between treatment groups could not be tested statistically because data were insufficient.

\section{Ankle-brachial pressure index}

Lee 2001 reported that $A B I$ in the cilostazol group dropped from $0.73 \pm 0.12$ to $0.69 \pm 0.11$, and the pentoxifylline group improved from $0.66 \pm 0.13$ to $0.7 \pm 0.14$. Study authors stated that none of these results were statistically significant, although they did not present test results. Dawson 2000 reported that $A B I$ increased in the cilostazol group from $0.66 \pm 0.18$ at baseline to $0.70 \pm 0.18$ at 24 weeks, and in the pentoxifylline group, $A B I$ increased from $0.66 \pm 0.21$ to $0.71 \pm 0.24$. ABI after 24 weeks was not statistically significantly different between treatment groups ( $P$ value not presented).

\section{Quality of life}

Lee 2001 did not measure quality of life. Dawson 2000 reported that no treatment significantly affected SF36 and WIQ scores.

\section{Side effects}

Dawson 2000 reported that rates of withdrawal due to adverse effects were similar in pentoxifylline (43/232) and cilostazol groups (36/227). Headache, diarrhoea and abnormal stools were significantly more common among participants receiving cilostazol than among those receiving pentoxifylline or placebo. Dawson 2000 reported that these adverse events were generally mild to moderate, were self-limiting and did not appear to affect the dropout rate.

\section{Pentoxifylline versus iloprost}

Creager 2008 compared iloprost ( $50 \mu \mathrm{g}, 100 \mu \mathrm{g}$ and $150 \mu \mathrm{g}$ ) versus pentoxifylline $(1200 \mathrm{mg})$ and placebo over six months.

\section{Pain-free walking distance}

PFWD increased by $24 \%, 28.9 \%$ and $31.2 \%$ for the iloprost $50 \mu \mathrm{g}$, $100 \mu \mathrm{g}$ and $150 \mu \mathrm{g}$ groups, respectively, and the increase for the pentoxifylline group was 34.3\% (Table 3). Creager 2008 reported no significant differences when comparing treatment groups versus placebo $(P$ value $=N S)$ but did not report on differences between iloprost and pentoxifylline.

\section{Total walking distance}

Iloprost comparisons showed that TWD increased in $50 \mu \mathrm{g}, 100 \mu \mathrm{g}$ and $150 \mu \mathrm{g}$ groups by $7.7 \%, 8.8 \%$ and $11.2 \%$, respectively. None of these changes were significant. Improvement with pentoxifylline over placebo was significant, as reported above, but trialists did not report on differences between iloprost and pentoxifylline (Table 4).

\section{Ankle-brachial pressure index}

Creager 2008 did not measure ABI.

\section{Quality of life}

Quality of life was measured using the WIQ and the SF36. According to Creager 2008, the SF36 showed no differences between treatment groups, and the WIQ showed significant differences only in stair climbing between iloprost and placebo, and between pentoxifylline and placebo. Again, trialists did not report on differences between iloprost and pentoxifylline.

\section{Side effects}

Creager 2008 reported side effects for the iloprost, pentoxifylline and placebo groups. The most common side effects in the pentoxifylline group were headache (19\%), pain in extremity (14\%) and dyspepsia (13\%), and side effects in the iloprost groups were mainly headache, vasodilation or flushing, pain in extremity, jaw pain, nausea and diarrhoea. For most adverse events, severity increased with increasing dose of iloprost.

\section{Pentoxifylline versus buflomedil and nifedipine}

Chacon-Quevedo 1994 compared pentoxifylline (1200 mg daily) versus buflomedil (600 mg daily) and nifedipine ( $60 \mathrm{mg}$ daily) over 90 days (three months). A total of 45 individuals participated in the study (15 in each group).

\section{Pain-free walking distance}

PFWD increased in the pentoxifylline group from $109 \pm 63 \mathrm{~m}$ to 194 $\pm 72 \mathrm{~m}$, for improvement of $78 \%$, compared with buflomedil $(97$ $\pm 73 \mathrm{~m}$ to $160 \pm 73 \mathrm{~m}$ ), which showed improvement of $64.9 \%$ and nifedipine ( $109 \pm 56 \mathrm{~m}$ to $194 \pm 65 \mathrm{~m}$ ), with $78 \%$ improvement (Table 3).

\section{Total walking distance}

TWD increased in the pentoxifylline group from $180 \pm 67 \mathrm{~m}$ to 226 $\pm 57 \mathrm{~m}$ compared with buflomedil ( $159 \pm 76 \mathrm{~m}$ to $205 \pm 66 \mathrm{~m}$ ) and nifedipine ( $186 \pm 54 \mathrm{~m}$ to $226 \pm 49 \mathrm{~m}$ ) (Table 4).

Chacon-Quevedo 1994 concluded that at 90 days, pentoxifylline was statistically better than buflomedil but not nifedipine in 
improving walking distance, but investigators did not specify the subtype (PFWD or TWD) nor the results of statistical tests.

\section{Ankle-brachial pressure index}

Chacon-Quevedo 1994 reported that improvement in ABI for the pentoxifylline group $(0.64 \pm 0.14$ to $0.75 \pm 0.17)$ was statistically greater than for the buflomedil or nifedipine group, but study authors did not provide complete data.

\section{Quality of life}

Chacon-Quevedo 1994 did not measure quality of life.

\section{Side effects}

Chacon-Quevedo 1994 did not measure side effects.

\section{DISCUSSION}

Intermittent claudication (IC) is a symptom of peripheral arterial disease (PAD) that is associated with increased morbidity and mortality and poor quality of life. It reflects the presence of an underlying disease process that results in narrowing or maybe blockage of lower limb blood vessels. It is associated with the presence of atherosclerosis elsewhere in the vascular tree, especially in the coronary and cerebral circulations.

As this pathology cannot be reversed, the main aims of treatment are (1) to stop or slow progression of the disease to critical ischaemia, to prevent adverse events, and (2) to alleviate the severity of symptoms to improve quality of life.

It is widely accepted, although at times controversial, that treatment of PAD at the stage of IC is medical, and that revascularisation is not the treatment of choice. Large numbers of interventions have been developed. Lifestyle changes and exercise are the basic essential interventions; they have a significant effect on both disease progression and symptoms. Other essential drugs like statins are very important for slowing the disease but have little effect on the symptoms. Pentoxifylline is one of many drugs used to relieve symptoms of IC and to improve quality of life.

\section{Summary of main results}

In comparing pentoxifylline with placebo, 11 studies reported painfree walking distance (PFWD). The duration of studies ranged from four to 40 weeks, and the pentoxifylline dose from $600 \mathrm{mg}$ to $1600 \mathrm{mg}$. Baseline PFWD ranged from $27.1 \mathrm{~m}$ to $460 \mathrm{~m}$, with large variability in results. One study reported less improvement in PFWD over the duration of the trial in the pentoxifylline group than in the placebo group - with a difference as great as $33.8 \%$. On the other hand, maximum improvement in PFWD among participants receiving pentoxifylline was $73.9 \%$ more than in those given placebo.

A total of 14 studies reported total walking distance (TWD) as an outcome when comparing pentoxifylline versus placebo. Studies varied in duration from eight weeks to 52 weeks, and pentoxifylline dose from $400 \mathrm{mg}$ to $1800 \mathrm{mg}$, but most studies used $1200 \mathrm{mg}$. Baseline TWD ranged from $56 \mathrm{~m}$ to $678 \mathrm{~m}$, and for PFWD, results were highly variable. The minimum benefit of pentoxifylline shown was $1 \%$, and the maximum benefit was $155.9 \%$.

In one study, pentoxifylline showed greater improvement in PFWD when compared with Gingko biloba extract (GBE), buflomedil and iloprost; cilostazol showed greater improvement when compared with pentoxifylline; and prostaglandin E1 (PGE1) showed greater improvement when compared with pentoxifylline. Data from the second study, which evaluated PGE1 and pentoxifylline, are too limited to allow meaningful conclusions. For TWD, greater improvement was shown for pentoxifylline than for nylidrin, GBE and aspirin, and for cilostazol and flunarizine than for pentoxifylline. PGE1 showed greater improvement in TWD in one study, and data in the second study are currently too limited to permit meaningful conclusions.

Pentoxifylline appeared to be well tolerated in most studies, with gastrointestinal side effects, mainly nausea, reported most commonly. These effects appeared mild.

Most included studies suggested improvement in PFWD and TWD for pentoxifylline over placebo (and other treatments), but the statistical significance of findings from individual trials is unclear, and pentoxifylline showed no improvement in $A B I$. It is important to appreciate the difference between statistical significance and clinical significance; even when a statistically significant improvement is described, improvement of a few metres might not make much difference to a patient.

\section{Overall completeness and applicability of evidence}

This review shows great variability between trial outcomes with pentoxifylline treatment. This helps to explain the large number of studies of pentoxifylline for IC that have been performed over three decades. Positive results in some studies were often only marginal, and across studies were generally inconsistent, encouraging further research to attain consistency.

Large variability in the results of studies included in this review was not unexpected. These studies used different doses of pentoxifylline, over variable durations, in different countries and by various study designs, but the variety of participant characteristics is most important. Investigators stated that they included individuals with IC Fontaine class II, but baseline walking distance varied from $27.1 \mathrm{~m}$ to $460 \mathrm{~m}$ for PFWD, and from 56 $\mathrm{m}$ to $678 \mathrm{~m}$ for TWD. This suggests considerable variation in the characteristics of participant groups across studies. Most researchers stated that baseline variables were comparable between intervention and control groups but did not specify these variables.

Only two studies reported use of an exercise programme in addition to pentoxifylline or comparison treatments. The remaining studies did not report an exercise programme or indicated that no formal programme was used. Some studies advised participants to stop smoking for the duration of the study. Advice on exercise and smoking appears inconsistent between studies, and effects of this on overall outcomes and placebo effects are unknown.

\section{Quality of the evidence}

We judged the overall quality of the evidence to be low. For most included studies, the risk of bias is unclear, mainly because insufficient information is available to permit judgement of low or high risk of bias. This was the case for selection bias, blinding, detection bias in particular, attrition bias and bias due to selective reporting. 
The quality of the evidence is severely limited by the heterogeneity of included studies. Study duration varied from four weeks to 52 weeks. Pentoxifylline doses used for the intervention group varied. Most studies used $1200 \mathrm{mg}$, but doses from $400 \mathrm{mg}$ to $1800 \mathrm{mg}$ were reported. Variability in outcomes was evident in that studies assessed PFWD, TWD or both. In addition, different treadmill protocols that ranged from constant load tests to graded tests were used to measure PFWD and TWD. Some studies did not report the treadmill protocol used. PFWD and TWD were reported as means, geometric means, seconds to percentage change from baseline and ratios. Thus we could not perform a pooled analysis.

\section{Potential biases in the review process}

In this systematic review, we identified all randomised controlled trials (RCTs) that compared pentoxifylline versus placebo or other pharmacological interventions. Open, cohort and single-blinded studies were not included because pentoxifylline has been studied extensively, and research authors identified a considerable number of RCTs. Comparisons of lifestyle changes and exercise were not included because no evidence has supported their inclusion in any treatment plan. As IC is a long-term condition, we included studies with a minimum duration of four weeks. We believe our search for RCTs has been comprehensive, and it is unlikely that our standardised methods of study selection and data extraction could have introduced major bias. Heterogeneity of included studies and variable presentation of outcomes by trialists (requiring substantial data imputation) precluded pooling of data.

\section{Agreements and disagreements with other studies or reviews}

A systematic review published in 2012 compared pentoxifylline, cilostazol and naftidrofuryl oxalate versus placebo, or versus one another, for the treatment of intermittent claudication in individuals with peripheral arterial disease (Stevens 2012). The Stevens 2012 review included four studies that were also included in our review - three comparing pentoxifylline versus placebo, and one comparing pentoxifylline versus cilostazol. Study authors employed imputation techniques to include study data in metaanalyses that we ourselves did not use because of heterogeneity. Their results revealed possible increases in both PFWD and TWD for pentoxifylline groups, with percent changes of 9\% $(95 \%$ credible interval $2 \%$ to $22 \%$ ) and $11 \%$ (95\% credible interval $1 \%$ to $24 \%$ ), respectively. Adverse events were not reported in the meta-analysis, but with all vasoactive drugs, mild headaches and gastrointestinal issues were reported, and no increase in cardiovascular events or deaths was described for pentoxifylline, cilostazol or naftidrofuryl oxalate. Study authors noted that heterogeneity in quality of life reporting prevented them from reporting these findings in their review. However, these data are presented as part of Squires 2010 and Squires 2011, in technology assessment reports written for the National Institute for Health and Care Excellence (NICE) and in a recent study evaluating the costeffectiveness of various treatments (Meng 2014; NICE 2011; NICE 2012).

Other systematic reviews on pentoxifylline for intermittent claudication have yielded results (Ernst 1994; Frampton 1995) similar to the findings of this review. Greater improvement in PFWD and TWD was shown for pentoxifylline versus placebo, but review authors concluded that clinical effects remain unclear and may depend on patient characteristics, such as $A B I$, duration of intermittent claudication, whether risk factors were addressed and whether other treatment options had been investigated.

\section{AUTHORS' CONCLUSIONS}

\section{Implications for practice}

Given the generally poor quality of published studies and the large degree of heterogeneity apparent among interventions and results, the overall benefit of pentoxifylline for patients with Fontaine class II intermittent claudication remains uncertain, but the medication is generally well tolerated.

High-quality data are currently insufficient to show the benefits of pentoxifylline for intermittent claudication.

\section{Implications for research}

Numerous studies on pentoxifylline for intermittent claudication over more than 30 years have reported highly variable outcomes. Whilst this comprehensive review summarises and critiques all available RCT evidence, and should prove helpful to clinicians and healthcare professionals in making informed decisions regarding pentoxifylline for the treatment of patients with intermittent claudication, the role of pentoxifylline in treatment remains uncertain. However, valuable research resources might be better directed toward discovery of more effective treatments or prevention measures.

\section{ACKNOWLEDGEMENTS}

We would like to thank Cochrane Vascular for help provided in updating this review. 


\section{RE F E R E N C E S}

\section{References to studies included in this review}

\section{Accetto 1982 \{published data only\}}

Accetto B. Beneficial hemorheologic therapy of chronic peripheral arterial disorders with pentoxifylline: results of double-blind study versus vasodilator-nylidrin. American Heart Journal 1982;103(5):864-9.

\section{Belcaro 2002 \{published data only\}}

Belcaro G, Nicolaides AN, Griffin M, De Sanctis MT, Cesarone MR, Incandela L, et al. Intermittent claudication in diabetics: treatment with exercise and pentoxifylline - a 6-month, controlled, randomized trial. Angiology 2002;53 Suppl 1:39-43.

\section{Bohmer 1988 \{published data only\}}

Bohmer D, Kalinski S, Michaelis P, Szogy A. [Efficacy and tolerance of Ginkgo biloba extract compared to that of pentoxifylline in the treatment of patients suffering from peripheral chronic arterial occlusive disease] [German]. Hers Kreislauf 1988;20(1):5-8.

\section{Bollinger 1977 \{published data only\}}

Bollinger A, Frei $\mathrm{CH}$. Double-blind study of pentoxifylline against placebo in patients with intermittent claudication. Pharmatherapeutica 1977;1(9):557-62.

\section{Cesarone 2002b \{published data only\}}

Cesarone MR, Belcaro G, Nicolaides AN, Griffin M, De Sanctis MT, Incandela $\mathrm{L}$, et al. Treatment of severe intermittent claudication with pentoxifylline: a 40-week, controlled, randomized trial. Angiology 2002;53 Suppl 1:1-5.

\section{Chacon-Quevedo 1994 \{published data only\}}

Chacon-Quevedo A, Eguaras MG, Calleja F, Garcia MA, Roman M, Casares J, et al. Comparative evaluation of pentoxifylline, buflomedil, and nifedipine in the treatment of intermittent claudication of the lower limbs. Angiology 1994;45(7):647-53.

\section{Ciocon 1997 \{published data only\}}

Ciocon JO, Galindo-Ciocon D, Galindo DJ. A comparison between aspirin and pentoxifylline in relieving claudication due to peripheral vascular disease in the elderly. Angiology 1997;48(3):237-40.

\section{Creager 2008 \{published data only\}}

Creager MA, Pande RL, Hiatt WR. A randomized trial of iloprost in patients with intermittent claudication. Vascular Medicine 2008;13(1):5-13.

\section{Dawson 2000 \{published data only\}}

Dawson DL, Beebe HG, Herd JA, Chinoy DA, Davidson MH, Hiatt WR, et al. Cilostozol or pentoxifylline for claudication. Circulation 1998;98 Suppl 1:1-12.

* Dawson DL, Cutler BS, Hiatt WR, Hobson RW 2nd, Martin JD, Bortey EB, et al. A comparison of cilostazol and pentoxifylline for treating intermittent claudication. American Journal of Medicine 2000;109(7):523-30.
Dawson DL, Zheng Q, Worthy SA, Charles B, Bradley DV Jr. Failure of pentoxifylline or cilostazol to improve blood and plasma viscosity, fibrinogen, and erythrocyte deformability in claudication. Angiology 2002;53(5):509-20.

De Sanctis 2002a \{published data only\}

De Sanctis MT, Cesarone MR, Belcaro G, Nicolaides AN, Griffin M, Incandela $\mathrm{L}$, et al. Treatment of intermittent claudication with pentoxifylline: a 12-month, randomized trial - walking distance and microcirculation. Angiology 2002;53 Suppl 1:7-12.

\section{De Sanctis 2002b \{published data only\}}

De Sanctis MT, Cesarone MR, Belcaro G, Nicolaides AN, Griffin M, Incandela L, et al. Treatment of long-distance intermittent claudication with pentoxifylline: a 12-month, randomized trial. Angiology 2002;53 Suppl 1:13-17.

Di Perri 1983 \{published data only\}

Di Perri T, Guerrini M. Placebo controlled double blind study with pentoxifylline of walking performance in patients with intermittent claudication. Angiology 1983;34(1):40-5.

Donaldson 1984 \{published data only\}

* Donaldson DR, Hall TJ, Kester RC, Ramsden CW, Wiggins PA. Does oxpentifylline ('Trental') have a place in the treatment of intermittent claudication?. Current Medical Research and Opinion 1984;9(1):35-40.

Donaldson DR, Kester RC, Russell CW, Wiggins PA, Hall TJ. Does oxpentifylline (Trental) have a place in the treatment of intermittent claudication?. Clinical Hemorheology. 1 1981; Vol. 1 , issue 5-6:469.

\section{Ernst 1992 \{published data only\}}

Ernst E, Kollar L, Resch KL. Does pentoxifylline prolong the walking distance in exercised claudicants? A placebo-controlled double-blind trial. Angiology 1992;43(2):121-5.

\section{Gallus 1985 \{published data only\}}

Gallus AS, Gleadow F, Dupont P, Walsh J, Morley AA, Wenzel A, et al. Intermittent claudication: a double-blind crossover trial of pentoxifylline. Australian and New Zealand Journal of Medicine 1985;15(4):402-9.

\section{Hepp 1992 \{published data only\}}

Hepp W, Von Bary S, Corovic D, Diehm C, Muhe E, Rudofsky G, et al. Clinical comparison of the effect of I.U. prostaglandin E1 and I.U. pentoxifylline in patients with arterial occlusive disease [Vergleich der klinischen wirksamkeit von i.v. prostaglandin E1 und i.v. pentoxifyllin bei patienten mit arterieller verschlubkrankheit im stadium llb nach fontaine]. Vasa. 21 1992; Vol. 21, issue 4:447 Abstract No. 6.3.

Hepp W, Von Bary S, Corovic D, Diehm C, Muhe E, Rudofsky G, et al. Intravenous prostaglandin E1 versus pentoxifylline: a randomized controlled study in patients with intermittent claudication. International Angiology. 14 1995; Vol. 14 Suppl $1: 280$. 
* Hepp W, Von Bary S, Corovic D, Diehm C, Muhe E, Rudofsky G, et al. Therapeutic effectiveness of PGE1 intravenous administered comparising with Pentoxifylline on intermittent claudication. Angiology 1992;14(2):59-64.

Hepp W, von Bary S, Corovic D, Diehm C, Muhe E, Rudofsky G, et al. Randomized study comparing the clinical effectiveness of intravenous prostaglandin E1 and intravenous pentoxifylline in patients with Fontaine stage IIb arterial occlusive disease [Randomisierte studie zum vergleich der klinischen wirksamkeit von i.v. prostaglandin E1 and i.v. pentoxifyllin bei patienten mit arterieller verschlubkrankheit im stadium Ilb nach fontaine]. Vasa-Supplementum 1991;33:348-9.

\section{Kiesewetter 1988 \{published data only\}}

Kiesewetter H, Blume J, Jung F, Waldhausen P, Gerhards M. Intermittent claudication. Increase in walking distance and improvement of hemorheologic parameters by pentoxifylline (trental 400). MMW, Munchener Medizinische Wochenschrift 1988;130:357-60.

\section{Lee 2001 \{published data only\}}

Lee TM, Su SF, Hwang JJ, Tseng CD, Chen MF, Lee YT, et al. Differential lipogenic effects of cilostazol and pentoxifylline in patients with intermittent claudication: potential role for interleukin-6. Atherosclerosis 2001;158(2):471-6.

* Lee TM, Su SF, Tsai CH, Lee YT, Wang SS. Differential effects of cilostazol and pentoxifylline on vascular endothelial growth factor in patients with intermittent claudication. Clinical Science 2001;101(3):305-11.

\section{Lindgarde 1989 \{published data only\}}

Lindgarde F, Jelnes R, Bjorkman H, Adielsson G, Kjellstrom T, Palmquist I, et al. Conservative drug treatment in patients with moderately severe chronic occlusive peripheral arterial disease. Scandinavian Study Group. Circulation 1989;80(6):1549-56.

\section{Perhoniemi 1984 \{published data only\}}

Perhoniemi V, Salmenkivi K, Sundberg S, Johnsson R, Gordin A. Effects of flunarizine and pentoxifylline on walking distance and blood rheology in claudication. Angiology 1984;35(6):366-72.

\section{Porter 1982a \{published data only\}}

Gillings D, Koch G, Reich T, Stager WJ. Another look at the pentoxifylline efficacy data for intermittent claudication. Journal of Clinical Pharmacology 1987;27(8):601-9.

* Porter JM, Cutler BS, Lee BY, Reich T, Reichle FA, Scogin JT, et al. Pentoxifylline efficacy in the treatment of intermittent claudication: multicenter controlled double-blind trial with objective assessment of chronic occlusive arterial disease patients. American Heart Journal 1982;104(1):66-72.

Reich T, Cutler BC, Lee BY, Porter JM, Reichle FA, Scogin JT, et al. Pentoxifylline in the treatment of intermittent claudication of the lower limbs. Angiology 1984;35(7):389-95.

Reich T, Gillings D. Effects of pentoxifylline on severe intermittent claudication. Angiology 1987;38(9):651-6.

\section{Porter 1982b \{published data only\}}

Porter JM, Bauer GM. Pharmacologic treatment of intermittent claudication. Surgery 1982;92(6):966-71.

Schellong 2012 \{published data only\}

NCT01263925. Prostaglandin E1 in outpatients with intermittent claudication. https://clinicaltrials.gov/ct2/show/NCT01263925.

Schellong S, Baron Von Bilderling P, Grus JD, Lawall H, Grieger F, $\mathrm{Ney} U$, et al. Intravenous alprostadil treatment compared to oral pentoxifylline treatment in outpatients with intermittent claudication: results of a clinical study. Vasa - Journal of Vascular Diseases 2012;41:78.

Volker 1978 \{published data only\}

Volker D. [Treatment of arterial diseases with trental 400. Results of a double-blind study]. Die Medizinische Welt 1978;29(32):1244-7.

\section{References to studies excluded from this review}

Bieron 2005 \{published data only\}

Bieron K, Kostka-Trabka E, Starzyk D, Goszcz A, Grodzinska L, Korbut R. Bencyclane - A new aspect of the mechanism of action in patients with peripheral arterial occlusive disease. Open-label, prospective, randomized trial. Acta Angiologica 2005;11(3):157-72.

\section{Ciuffetti 1991 \{published data only\}}

Ciuffetti G, Mercuri M, Ott C, Lombardini R, Paltriccia R, Lupattelli $G$, et al. Use of pentoxifylline as an inhibitor of free radical generation in peripheral vascular disease. Results of a double-blind placebo-controlled study. European Journal of Clinical Pharmacology 1991;41(6):511-5.

\section{Dawson 1999 \{published data only\}}

Dawson DL, DeMaioribus CA, Hagino RT, Light JT, Bradley DV Jr, Britt KE, et al. The effect of withdrawal of drugs treating intermittent claudication. American Journal of Surgery 1999;178(2):141-6.

\section{Dettori 1989 \{published data only\}}

Dettori AG, Pini M, Moratti A, Paolicelli M, Basevi P, Quintavalla R, et al. Acenocoumarol and pentoxifylline in intermittent claudication. A controlled clinical study. The APIC Study Group. Angiology 1989;40(4 part 1):237-48.

\section{Ehrly 1986 \{published data only\}}

Ehrly AM, Saeger-Lorenz K. Effect of pentoxifylline on the muscle tissue oxygen pressure of claudicants after pedoergometric exercise. Angiology. 37 1986; Vol. 37, issue 5:398.

\section{Ehrly 1987 \{published data only\}}

Ehrly AM, Saeger-Lorenz K. Influence of pentoxifylline on muscle tissue oxygen tension (pO2) of patients with intermittent claudication before and after pedal ergometer exercise. Angiology 1987;38(2 part 1):93-100. 


\section{Farkas 1993 \{published data only\}}

Farkas K, Horvath P, Farsang C. Pentoxifylline treatment of patients with peripheral obstructive vascular disease. International Angiology. 12 1993; Vol. 12:64.

\section{Fossat 1995 \{published data only\}}

Fossat C, Fabre D, Alimi Y, Bienvenu J, Aillaud MF, Lenoble M, et al. Leukocyte activation study during occlusive arterial disease of the lower limb: effect of pentoxifylline infusion. Journal of Cardiovascular Pharmacology 1995;25 Suppl 2:96-100.

\section{Guest 2005 \{published data only\}}

Guest JF, Davie AM, Clegg JP. Cost effectiveness of cilostazol compared with naftidrofuryl and pentoxifylline in the treatment of intermittent claudication in the UK. Current Medical Research and Opinion 2005;21(6):817-26.

\section{Hepp 1996 \{published data only\}}

Hepp W, Von Bary S, Corovic D, Diehm C, Muhe E, Rudofsky G, et al. Clinical efficacy of IV prostaglandin E1 and IV pentoxifylline in patients with arterial occlusive disease of fontaine stage Ilb: a multicenter, randomized comparative study. International Journal of Angiology 1996;5(1):32-7.

\section{Horowitz 1982 \{published data only\}}

Horowitz I. Results of a multicenter randomised double blind study. Pentoxyifylline versus placebo for 6 months on lower limb artertiopathies [Resultats d'une etude multicentrique randomisee en double aveugle. Pentoxifylline contre placebo prolongee sur 6 mois dans les arteriopathies des membres inferieurs]. Actualities D'Angiologie 1982;7:31-4.

\section{Incandela 2002 \{published data only\}}

Incandela L, De Sanctis MT, Cesarone MR, Belcaro G, Nicolaides AN, Geroulakos G, et al. Short-range intermittent claudication and rest pain: microcirculatory effects of pentoxifylline in a randomized, controlled trial. Angiology 2002;53 Suppl 1:27-30.

\section{Kellner 1976 \{published data only\}}

Kellner H. Treatment of chronic arterial circulatory disorders. Double blind trial with Trental 400. MMW, Munchener Medizinische Wochenschrift 1976;118(43):1399-402.

\section{Luk'Janov 1995 \{published data only\}}

Luk'Janov Y. Hemorheologic and hemodynamic changes after treatments with PGE versus pentoxifylline (PF) in patients with peripheral arterial disease (PAD). International Angiology. 14 1995; Vol. 14 Suppl 1:372.

Milio 2003 \{published data only\}

Milio G, Cospite V, Cospite M. Effects of PGE-1 in patients suffering from peripheral arterial occlusive disease. Minerva Cardioangiologica 2003;51(3):311-6.

\section{Milio 2006 \{published data only\}}

Milio G, Coppola G, Novo S. The effects of prostaglandin E-1 in patients with intermittent claudication. Cardiovascular \& Hematological Disorders Drug Targets 2006;6(2):71-6.

\section{Panchenko 1997 \{published data only\}}

Panchenko E, Eshkeeva A, Dobrovolsky A, Titaeva E, Podinovskaya Y, Hussain KM, et al. Effects of indobufen and pentoxifylline on walking capacity and hemostasis in patients with intermittent claudication: results of six months treatment. Angiology 1997;48(3):247-54.

Pignoli 1985 \{published data only\}

Pignoli P, Ciccolo F, Villa V, Longo T. Comparative evaluation of buflomedil and pentoxifylline in patients with peripheral arterial occlusive disease. Current Therapeutic Research 1985;37(4):596-606.

\section{Poggesi 1985 \{published data only\}}

Poggesi L, Scarti L, Boddi M, Masotti G, Serneri GG. Pentoxifylline treatment in patients with occlusive peripheral arterial disease. Circulatory changes and effects on prostaglandin synthesis. Angiology 1985;36(9):628-37.

\section{Regenthal 1991 \{published data only\}}

Regenthal R, Voigt H, Reuter W, Preiss R. The effect of oral trapidil therapy on clinical and hemorheological parameters in arteriosclerosis obliterans in comparison to pentoxifylline - a pilot study [On the influence of the oral trapidil therapy on clinical and haemorrheologic parameters in arteriosclerosis obliterans in comparison to pentoxifylline - a pilot study]. Zeitschrift fur die Gesamte Innere Medizin und Ihre Grenzgebiete 1991;46(6):185-90

\section{Reilly 1987 \{published data only\}}

Reilly DT, Quinton DN, Barrie WW. A controlled trial of pentoxifylline (Trental 400) in intermittent claudication: clinical, haemostatic and rheological effects. New Zealand Medical Journal 1987;100(828):445-7.

Rodin 1998 \{published data only\} Rodin SM. Pletal (cilostazol) tablets. Center for Drug Evaluation and Research. Application number: NDA 20-863,. Study 21-96-202 1998; Vol. Study 21-96-202:27-40.

Rodin 1998a \{published data only\}

Rodin SM. Pletal (cilostazol) Tablets. Center for Drug Evaluation and Research. Application number: NDA 20-863 Otsuka America,. Study 21-94-301 1998; Vol. Study 21-94-301:58-72.

Roekaerts 1984 \{published data only\}

Roekaerts F, Deleers L. Trental 400 in the treatment of intermittent claudication: results of long-term, placebocontrolled administration. Angiology 1984;35(7):396-406.

\section{Rudofsky 1987 \{published data only\}}

Rudofsky G, Haussler KF, Kunkel HP, Schneider-May H, Spengel F, Symann O, et al. Effectiveness of intravenous infusion treatment of peripheral arterial occlusive disease with Trental - results of a multicenter double-blind study [Zur wirksamkeit einer intravenosen infusionbehandlung der peripheren arteriellen verschlubkrankheit mit Trental Ergebnisse einer multi-zentrischen doppelblindstudie]. VasaSupplementum 1987;20:375-8. 
Rudofsky 1988 \{published data only\}

Rudofsky G, Haussler KF, Kunkel HP, Schneider-May H, Spengel F, Symann O, et al. Intravenous pentoxifylline treatment in chronic peripheral arterial disease. Die Medizinische Welt 1988;39(39):1136-40.

Rudofsky 1989 \{published data only\} Rudofsky G, Haussler KF, Kunkel HP, Schneider-May H, Spengel F, Symann O, et al. Intravenous treatment of chronic peripheral occlusive arterial disease: a double-blind, placebocontrolled, randomized, multicenter trial of pentoxifylline. Angiology 1989;40(7):639-49.

\section{Scheffler 1991 \{published data only\}}

Scheffler P, de la Hamette D, Muller H. [Controlled vascular training in IIb peripheral arterial occlusive disease: additive effect of intravenous PGE1 versus intravenous pentoxifylline during training]. [German]. Vasa - Supplementum 1991;33:350-2.

\section{Scheffler 1994 \{published data only\}}

Scheffler P, de la Hamette D, Gross J, Mueller H, Schieffer H. Intensive vascular training in stage IIb of peripheral arterial occlusive disease. The additive effects of intravenous prostaglandin E1 or intravenous pentoxifylline during training. Circulation 1994;90(2):818-22.

\section{Schubotz 1976 \{published data only\}}

Schubotz R. Double-blind trial of pentoxifylline in diabetics with peripheral vascular disorders. Pharmatherapeutica 1976;1(3):172-9.

\section{Shustov 1997 \{published data only\}}

Shustov SB, Canova N. Controlled clinical trial on the efficacy and safety of oral sulodexide in patients with peripheral occlusive arterial disease. Current Medical Research and Opinion 1997;13(10):573-82.

\section{Singh 2009 \{published data only\}}

Singh S, Singh H, Kohli A, Kapoor V, Singh G. Effects of cilostazole and pentoxifylline on claudication distance and lipid profile in patients with occlusive peripheral arterial disease: a comparative trial. Indian Journal of Thoracic Cardiovascular Surgery 2009;25:45-8.

\section{Strano 1984 \{published data only\}}

Strano A, Davi G, Avellone G, Novo S, Pinto A. Double-blind, crossover study of the clinical efficacy and the hemorheological effects of pentoxifylline in patients with occlusive arterial disease of the lower limbs. Angiology 1984;35(7):459-66.

\section{Strano 2002 \{published data only\}}

Strano A. Propionyl-L-carnitine versus pentoxifylline: improvement in walking capacity in patients with intermittent claudication. Clinical Drug Investigation 2002;22 Suppl 1:1-6.

\section{Thomson 1990 \{published data only\}}

Thomson GJ, Thomson S, Todd AS, Vohra RK, Carr MH, Walker MG. Combined intravenous and oral pentoxifylline in the treatment of peripheral vascular disease. A clinical trial. International Angiology 1990;9(4):266-70.

\section{Tonak 1977 \{published data only\}}

Tonak J, Knecht H, Groitl H. Treatment of circulation disorders with pentoxifylline. A double-blind study with Trental [Zur behandlung von durchblutungsstorungen mit pentoxifyllin. Eine doppelblindstudie mit trental]. Medizinische Monatsschrift 1977;31(10):467-72.

Triebe 1992 \{published data only\}

Triebe G, Munnich U, Liebold F. [A therapeutic comparison between hemodilution and pentoxifylline in arterial obstructive disease. An objective assessment by quantitative Doppler sonography]. [German]. Deutsche Medizinische Wochenschrift 1992;117(14):523-30.

Tsang 1994 \{published data only\}

Tsang GM, Sanghera K, Gosling P, Smith FC, Paterson IS, Simms MH, et al. Pharmacological reduction of the systemically damaging effects of local ischaemia. European Journal of Vascular Surgery 1994;8(2):205-8.

Wang 2003 \{published data only\}

Wang T, Elam MB, Forbes WP, Zhong J, Nakajima K. Reduction of remnant lipoprotein cholesterol concentrations by cilostazol in patients with intermittent claudication. Atherosclerosis 2003;171(2):337-42.

\section{Additional references}

\section{Bachoo 2010}

Bachoo P, Thorpe PA, Maxwell H, Welch K. Endovascular stents for intermittent claudication. Cochrane Database of Systematic Reviews 2010, Issue 1. [DOI: 10.1002/14651858.CD003228.pub2]

\section{Bedenis 2014}

Bedenis R, Stewart M, Cleanthis M, Robless P, Mikhailidis DP, Stansby G. Cilostazol for intermittent claudication. Cochrane Database of Systematic Reviews 2014, Issue 10. [DOI: 10.1002/14651858.CD003748.pub4]

\section{Dawson 2002}

Dawson DL, Zheng Q, Worthy SA, Charles B, Bradley DV Jr. Failure of pentoxifylline or cilostazol to improve blood and plasma viscosity, fibrinogen, and erythrocyte deformability in claudication. Angiology 2002;53(5):509-20.

\section{de Backer 2012}

de Backer TLM, Vander Stichele R, Lehert P, Van Bortel L. Naftidrofuryl for intermittent claudication. Cochrane Database of Systematic Reviews 2012, Issue 12. [DOI: 10.1002/14651858.CD001368.pub4]

\section{de Backer 2013}

de Backer TLM, Vander Stichele R. Buflomedil for intermittent claudication. Cochrane Database of Systematic Reviews 2013, Issue 3. [DOI: 10.1002/14651858.CD000988.pub4]

\section{Ernst 1994}

Ernst E. Pentoxifylline for intermittent claudication. A critical review. Angiology 1994;45(5):339-45. 


\section{Fontaine 1954}

Fontaine VR, Kim M, Kieny R. Surgical treatment of peripheral circulation disorders [Die chirurgische Behandlung der peripheren Durchblutungsstörungen]. Helvetica Chirurgica Acta 1954;21(5-6):499-533.

\section{Fowkes 1998}

Fowkes G, Gillespie IN. Angioplasty (versus non surgical management) for intermittent claudication. Cochrane Database of Systematic Reviews 1998, Issue 2. [DOI: 10.1002/14651858.CD000017]

\section{Fowkes 2013}

Fowkes FGR, Rudan D, Rudan I, Aboyans V, Denenberg JO, McDermott MM, et al. Comparison of global estimates of prevalence and risk factors for peripheral artery disease in 2000 and 2010: a systematic review and analysis. Lancet 2013;382(9901):1329-40.

\section{Frampton 1995}

Frampton JE, Brogden RN. Pentoxifylline (oxpentifylline). A review of its therapeutic efficacy in the management of peripheral vascular and cerebrovascular disorders. Drugs \& Aging 1995;7(6):480-503.

\section{Gillings 1987}

Gillings D, Koch G, Reich T, Stager WJ. Another look at the pentoxifylline efficacy data for intermittent claudication. Journal of Clinical Pharmacology 1987;27(8):601-9.

\section{Higgins 2011}

Higgins JPT, Green S, editors. Cochrane Handbook for Systematic Reviews of Interventions Version 5.1.0 [updated March 2011]. The Cochrane Collaboration, 2011. Available from www.cochrane-handbook.org.

\section{Lane 2014}

Lane R, Ellis B, Watson L, Leng GC. Exercise for intermittent claudication. Cochrane Database of Systematic Reviews 2014, Issue 7. [DOI: 10.1002/14651858.CD000990.pub3]

\section{Lee 2001a}

Lee TM, Su SF, Hwang JJ, Tseng CD, Chen MF, Lee YT, et al. Differential lipogenic effects of cilostazol and pentoxifylline in patients with intermittent claudication: potential role for interleukin-6. Atherosclerosis 2001;158(2):471-6.

\section{Meijer 2002}

Meijer WT, Cost B, Bernsen RM, Hoes AW. Incidence and management of intermittent claudication in primary care in The Netherlands. Scandinavian Journal of Primary Health Care 2002;20(1):33-4.

\section{Meng 2014}

Meng Y, Squires H, Stevens JW, Simpson E, Harnan S, Thomas S, et al. Cost-effectiveness of cilostazol, naftidrofuryl oxalate, and pentoxifylline for the treatment of intermittent claudication in people with peripheral arterial disease. Angiology 2014;65(3):190-7.

\section{Micromedex 2002}

MICROMEDEX, Englewood, Colorado (Edition expires [12/2002]). MICROMEDEX ${ }^{\circledast}$ Healthcare Series. http://rs.lendac.ie/m\&p.html.

\section{Moher 2000}

Moher D, Pham B, Ausejo M, Saenz A, Hood S, Barber GG. Pharmacological management of intermittent claudication: a meta-analysis of randomised trials. Drugs 2000;59(5):1057-70.

\section{NICE 2011}

National Institute for Health and Care Excellence (NICE). Cilostazol, naftidrofuryl oxalate, pentoxifylline and inositol nicotinate for the treatment of intermittent claudication in people with peripheral arterial disease. www.nice.org.uk/ guidance/TA223/chapter/2-Clinical-need-and-practice (accessed 5 April 2015).

\section{NICE 2012}

National Institute for Health and Care Excellence (NICE). Lower limb peripheral arterial disease: diagnosis and management. www.nice.org.uk/Guidance/CG147 (accessed 5 April 2015).

\section{Reich 1984}

Reich T, Cutler BC, Lee BY, Porter JM, Reichle FA, Scogin JT, et al. Pentoxifylline in the treatment of intermittent claudication of the lower limbs. Angiology 1984;35(7):389-95.

\section{Robertson 2013}

Robertson L, Andras A. Prostanoids for intermittent claudication. Cochrane Database of Systematic Reviews 2013, Issue 4. [DOI: 10.1002/14651858.CD000986.pub3]

\section{Squires 2010}

Squires H, Simpson E, Meng Y, Harnan S, Stevens J, Wong R. Cilostazol, naftidrofuryl oxalate, pentoxifylline and inositol nicotinate for intermittent claudication in people with peripheral arterial disease. Technology Assessment Report commissioned by the NIHR HTA Programme on behalf of the National Institute for Health and Clinical Excellence 2010.

\section{Squires 2011}

Squires H, Simpson E, Meng Y, Harnan S, Stevens J, Wong R, et al. A systematic review and economic evaluation of cilostazol, naftidrofuryl oxalate, pentoxifylline and inositol nicotinate for the treatment of intermittent claudication in people with peripheral arterial disease. Health Technology Assessment 2011;15(40):1-210.

\section{Stevens 2012}

Stevens JW, Simpson E, Harnan S, Squires H, Meng Y, Thomas S, et al. Systematic review of the efficacy of cilostazol, naftidrofuryl oxalate and pentoxifylline for the treatment of intermittent claudication. British Journal of Surgery 2012;99(12):1630-8.

\section{Tendera 2011}

Tendera M, Aboyans V, Bartelink M-L, Baumgartner I, Clement D, Collet J-P, et al. ESC Guidelines on the diagnosis and treatment of peripheral artery diseases. European Heart Journal 2011;32:2851-906. 


\section{Wong 2011}

Wong PF, Chong LY, Mikhailidis DP, Robless P, Stansby G. Antiplatelet agents for intermittent claudication. Cochrane Database of Systematic Reviews 2011, Issue 11. [DOI: 10.1002/14651858.CD001272]

\section{References to other published versions of this review}

\section{Salhiyyah 2005}

Salhiyyah K, Palfreyman SSJ, Booth A, Michaels JA, Senanayake E. Pentoxifylline for intermittent claudication.

\section{CHARACTERISTICS OF STUDIES}

Characteristics of included studies [ordered by study ID]
Cochrane Database of Systematic Reviews 2005, Issue 2. [DOI: 10.1002/14651858.CD005262]

\section{Salhiyyah 2012}

Salhiyyah K, Senanayake E, Abdel-Hadi M, Booth A, Michaels JA. Pentoxifylline for intermittent claudication. Cochrane Database of Systematic Reviews 2012, Issue 1. [DOI: 10.1002/14651858.CD005262.pub2]

* Indicates the major publication for the study

Accetto 1982

\begin{tabular}{|c|c|}
\hline Methods & $\begin{array}{l}\text { Study design: double-blinded, randomised } \\
\text { Country: Yugoslavia } \\
\text { Setting: single centre } \\
\text { Intention-to-treat: no }\end{array}$ \\
\hline Participants & $\begin{array}{l}\text { Number of participants randomly assigned: } 60 \\
\text { Number of participants analysed: } 47 \text { ( } 23 \text { pentoxifylline, } 24 \text { nylidrin } \mathrm{HCL} \text { ) } \\
\text { Exclusions post randomisation: } 13 \\
\text { Losses to follow-up: none } \\
\text { Age: mean } 61 \text { years (range } 30 \text { to } 80 \text { years) } \\
\text { Sex: } 36 \text { male, } 14 \text { female } \\
\text { Inclusion criteria: Fontaine stage II or III; initial claudication distance }>50 \text { m and }<500 \mathrm{~m} \text { at } 3 \mathrm{~km} / \mathrm{h} \text { at } 0 \\
\text { degrees of inclination; severity of disorder unchanged for } 6 \text { months } \\
\text { Exclusion criteria: advanced limb arterial occlusion; peripheral venous disorders; systemic haemato- } \\
\text { logical disorders; severely impaired renal function; GI disorders; hypersensitivities to methylxanthines; } \\
\text { women of childbearing age; taking cardiac medication, glycosides and antihypertensives or antibiotics } \\
<4 \text { weeks before the study }\end{array}$ \\
\hline
\end{tabular}

Treatment: oral pentoxifylline, $400 \mathrm{mg} 3$ times daily
Control: nylidrin $\mathrm{HCl}, 3 \mathrm{mg} 3$ times daily
Duration: 8 weeks

Outcomes

Primary: mean TWD

Secondary: side effects

\begin{tabular}{ll}
\hline Notes & Treadmill protocol: $3 \mathrm{~km} / \mathrm{h}$ without inclination \\
& Mean TWD stated in metres and seconds
\end{tabular}

\section{Risk of bias}


Accetto 1982 (Continued)

\begin{tabular}{lll} 
Bias & Authors' judgement & Support for judgement \\
\hline $\begin{array}{l}\text { Random sequence genera- } \\
\text { tion (selection bias) }\end{array}$ & Unclear risk & Not mentioned \\
\hline
\end{tabular}

\begin{tabular}{|c|c|c|}
\hline $\begin{array}{l}\text { Allocation concealment } \\
\text { (selection bias) }\end{array}$ & Unclear risk & Not mentioned \\
\hline $\begin{array}{l}\text { Blinding of participants } \\
\text { and personnel (perfor- } \\
\text { mance bias) } \\
\text { All outcomes }\end{array}$ & Unclear risk & Reports 'double blinded'; no other information available \\
\hline $\begin{array}{l}\text { Blinding of outcome as- } \\
\text { sessment (detection bias) } \\
\text { All outcomes }\end{array}$ & Unclear risk & Not mentioned \\
\hline $\begin{array}{l}\text { Incomplete outcome data } \\
\text { (attrition bias) } \\
\text { All outcomes }\end{array}$ & Unclear risk & Reasons for withdrawals not provided \\
\hline $\begin{array}{l}\text { Selective reporting (re- } \\
\text { porting bias) }\end{array}$ & Unclear risk & Protocol not available; insufficient information available to permit judgement \\
\hline Other bias & Low risk & Study appears free of other bias \\
\hline
\end{tabular}

Belcaro 2002

$\begin{array}{ll}\text { Methods } & \text { Study design: double-blinded, randomised } \\ \text { Country: Italy/USA/UK } \\ \text { Setting: } 3 \text { centres } \\ \text { Intention-to-treat: no }\end{array}$

Participants

\author{
Number of participants randomly assigned: 60 \\ Number of participants analysed: 53 (27 pentoxifylline, 26 placebo) \\ Exclusions post randomisation: 7 \\ Losses to follow-up: none
}

Age: pentoxifylline: $55 \pm 7$ years, placebo: $56 \pm 11$ years

Sex: M:F: pentoxifylline: 16:11, placebo: 18:8

Inclusion criteria: severe intermittent claudication with total walking distance $<100 \mathrm{~m}$; intermittent claudication $>3$ months; resting Doppler ankle brachial index $<0.8$; decrease in ankle pressure $>15$ $\mathrm{mmHg}$ after standard exercise test on treadmill;

age between 45 and 75 years; arterial stenoses, plaques and blood flow reduction due to arteriosclerosis (colour duplex); graded cardiac stress test showing no angina/MI; stable control of diabetes mellitus $\geq 5$ years

Exclusion criteria: presence of indication for vascular angioplasty or revascularisation; 
Belcaro 2002 (Continued)

angina or cardiac ischaemia on effort; previous coronary or vascular surgery or angioplasty, aneurysm, congestive heart failure, renal failure (creatinine $>2 \mathrm{mg} / \mathrm{dL}$ ) and diabetes requiring insulin; arthritis, pulmonary, cardiac, neoplastic inflammatory or immunologic disease

Exclusion criteria after run-in phase: variance of maximal walking distance $>25 \%$ during 2-week run-in phase

\begin{tabular}{|c|c|c|}
\hline Interventions & \multicolumn{2}{|c|}{$\begin{array}{l}\text { Treatment: oral pentoxifylline, } 400 \mathrm{mg} 4 \text { times daily } \\
\text { Control: placebo } \\
\text { Duration: } 6 \text { months }\end{array}$} \\
\hline Outcomes & \multicolumn{2}{|l|}{$\begin{array}{l}\text { Primary: mean TWD } \\
\text { Secondary: side effects }\end{array}$} \\
\hline Notes & \multicolumn{2}{|c|}{$\begin{array}{l}\text { Treadmill protocol: } 3 \mathrm{~km} / \mathrm{h} \text { at } 12 \% \text { inclination } \\
\text { Mean TWD expressed in metres only }\end{array}$} \\
\hline \multicolumn{3}{|l|}{ Risk of bias } \\
\hline Bias & Authors' judgement & Support for judgement \\
\hline $\begin{array}{l}\text { Random sequence genera- } \\
\text { tion (selection bias) }\end{array}$ & Unclear risk & States 'randomized'; no other information available \\
\hline $\begin{array}{l}\text { Allocation concealment } \\
\text { (selection bias) }\end{array}$ & Unclear risk & Not mentioned \\
\hline $\begin{array}{l}\text { Blinding of participants } \\
\text { and personnel (perfor- } \\
\text { mance bias) } \\
\text { All outcomes }\end{array}$ & Low risk & Treatment allocation blinded for participants and personnel \\
\hline $\begin{array}{l}\text { Blinding of outcome as- } \\
\text { sessment (detection bias) } \\
\text { All outcomes }\end{array}$ & Unclear risk & Not mentioned \\
\hline $\begin{array}{l}\text { Incomplete outcome data } \\
\text { (attrition bias) } \\
\text { All outcomes }\end{array}$ & Low risk & No incomplete outcome data \\
\hline $\begin{array}{l}\text { Selective reporting (re- } \\
\text { porting bias) }\end{array}$ & Unclear risk & Protocol not available; insufficient information available to permit judgement \\
\hline Other bias & Low risk & Study appears free of other bias \\
\hline
\end{tabular}

Bohmer 1988

Study design: double-blinded, randomised
Country: Germany
Setting: single centre
Intention-to-treat: not mentioned


Bohmer 1988 (Continued)

Participants

Number of participants randomly assigned: 27 (14 Ginkgo biloba extract, 13 pentoxifylline)

Number of participants analysed: 26

Exclusions post randomisation: none

Losses to follow-up: 1

Age: $60.3 \pm 7.3$ years (range 44 to 72 years)

Sex: 24 males, 3 females

Inclusion criteria: outpatient; high-grade stenosis for SFA; 1-side claudication; PFWD 50 to 200 m;

$<30 \%$ variance in WD during 3-week placebo induction phase

Exclusion criteria: not mentioned

\begin{tabular}{ll}
\hline Interventions & Treatment: pentoxifylline, $1200 \mathrm{mg} / \mathrm{d}$ \\
& Control: Ginkgo biloba extract, $160 \mathrm{mg} / \mathrm{d}$ \\
& Duration: 24 weeks \\
\hline Outcomes & Primary: mean PFWD, TWD \\
& Secondary: ABI \\
\hline Notes & Treadmill protocol: $3 \mathrm{~km} / \mathrm{h}$ at $5 \%$ inclination \\
& Mean PFWD and TWD expressed in metres only
\end{tabular}

\section{Risk of bias}

\begin{tabular}{lll}
\hline Bias & Authors' judgement & Support for judgement \\
\hline $\begin{array}{l}\text { Random sequence genera- } \\
\text { tion (selection bias) }\end{array}$ & Unclear risk & States 'randomised'; no other information provided \\
\hline $\begin{array}{l}\text { Allocation concealment } \\
\text { (selection bias) }\end{array}$ & Unclear risk & Not mentioned \\
\hline $\begin{array}{l}\text { Blinding of participants } \\
\text { and personnel (perfor- } \\
\text { mance bias) } \\
\text { All outcomes }\end{array}$ & Unclear risk & Reports 'double blind'; no other information available \\
\hline $\begin{array}{l}\text { Blinding of outcome as- } \\
\text { sessment (detection bias) } \\
\text { All outcomes }\end{array}$ & Unclear risk & Not mentioned \\
\hline $\begin{array}{l}\text { Incomplete outcome data } \\
\text { (attrition bias) }\end{array}$ & Low risk & No incomplete outcome data \\
\begin{tabular}{l} 
All outcomes \\
\hline $\begin{array}{l}\text { Selective reporting (re- } \\
\text { porting bias) }\end{array}$
\end{tabular} & Unclear risk & Protocol not available; insufficient information available to permit judgement \\
\hline \begin{tabular}{l} 
Other bias \\
\hline
\end{tabular} & Low risk & Study appears free of other bias \\
\hline
\end{tabular}


Bollinger 1977

Study design: double-blinded, randomised
Country: Switzerland
Setting: single centre
Intention-to-treat: not mentioned

Number of participants randomly assigned: 26
Number of participants analysed: 19
Exclusions post randomisation: none
Losses to follow-up: 7
Age: pentoxifylline: mean 63.9 years, placebo: mean 59.6 years
Sex: pentoxifylline: 9 male, 1 female, placebo: 8 male, 1 female
Inclusion criteria: intermittent claudication (Fontaine stage II)
Exclusion criteria: malleolar arteries could not be compressed by a cuff (mediasclerosis)

\begin{tabular}{ll}
\hline Interventions & Treatment: oral pentoxifylline, $200 \mathrm{mg} 3$ times daily \\
& Control: placebo \\
& Duration: 8 weeks \\
\hline Outcomes & Primary: mean TWD \\
& Secondary: ABI \\
\hline Notes & Treadmill protocol: $3.2 \mathrm{~km} / \mathrm{h}$ at $12.5 \%$ inclination \\
& Mean TWD expressed in metres only \\
& Participants were instructed to refrain from smoking during the study and to walk daily for at least 1 \\
hour
\end{tabular}

\section{Risk of bias}

\begin{tabular}{lll}
\hline Bias & Authors' judgement & Support for judgement \\
\hline $\begin{array}{l}\text { Random sequence genera- } \\
\text { tion (selection bias) }\end{array}$ & Unclear risk & $\begin{array}{l}\text { States 'allocated at random to receive treatments'; no other information pro- } \\
\text { vided }\end{array}$ \\
\hline $\begin{array}{l}\text { Allocation concealment } \\
\text { (selection bias) }\end{array}$ & Unclear risk & Not mentioned \\
\hline $\begin{array}{l}\text { Blinding of participants } \\
\text { and personnel (perfor- } \\
\text { mance bias) }\end{array}$ & Low risk & 'Both pentoxifylline and placebo were presented in identical tablet form and \\
All outcomes & supplied in containers of 40 tablets, identified only by a code number' \\
\hline $\begin{array}{l}\text { Blinding of outcome as- } \\
\text { sessment (detection bias) } \\
\text { All outcomes }\end{array}$ & Unclear risk & Not mentioned \\
\hline
\end{tabular}


Bollinger 1977 (Continued)

Incomplete outcome data Low risk No incomplete outcome data
(attrition bias)

All outcomes

Selective reporting (re- Unclear risk $\quad$ Protocol not available; insufficient information available to permit judgement
porting bias)

\begin{tabular}{ll}
\hline Other bias $\quad$ High risk $\quad$ Differences in clinical baseline data between treatment groups \\
\hline
\end{tabular}

\begin{tabular}{|c|c|}
\hline Methods & $\begin{array}{l}\text { Study design: double-blinded, randomised } \\
\text { Country: Italy } \\
\text { Setting: multi-centre - } 7 \text { centres } \\
\text { Intention-to-treat: yes }\end{array}$ \\
\hline Participants & $\begin{array}{l}\text { Number of participants randomly assigned: } 200 \\
\text { Number of participants analysed: } 178 \text { ( } 88 \text { pentoxifylline, } 90 \text { placebo) } \\
\text { Exclusions post randomisation: none } \\
\text { Losses to follow-up: } 22 \\
\text { Age: pentoxifylline: } 61 \pm 9 \text { years, placebo: } 61 \pm 10 \text { years } \\
\text { Sex: pentoxifylline: } 55 \text { males, } 45 \text { females, placebo: } 56 \text { males, } 44 \text { females } \\
\text { Inclusion criteria: severe intermittent claudication with total walking distance between } 50 \text { and } 200 \\
\text { m; intermittent claudication > } 4 \text { months; resting Doppler ankle-brachial index }<0.8 \text {; decrease in ankle } \\
\text { pressure > } 15 \text { mmHg after standard exercise rest on treadmill (12\% inclination, } 3 \text { km/h, } 10 \text { minutes of } \\
\text { exercise); age between } 45 \text { and } 75 \text { years; documentation of arterial stenoses, plaques and flow reduc- } \\
\text { tion due to arteriosclerosis by colour-duplex imaging } \\
\text { Exclusion criteria: indication for revascularisation or angioplasty; no angina or myocardial ischaemia } \\
\text { on effort tested by bicycle ergometry, cardiac risk factors; previous coronary or vascular surgery or } \\
\text { angioplasty; aneurysms; congestive heart failure NYHA III/IV; renal failure (creatinine }>2 \text { mg/100 mL); } \\
\text { insulin-dependent diabetes mellitus; change of > } \pm 25 \% \text { during 2-week run-in period; arthritis; pul- } \\
\text { monary, cardiac or neoplastic disease; inflammatory or immunologic disease }\end{array}$ \\
\hline Interventions & $\begin{array}{l}\text { Treatment: oral pentoxifylline, } 400 \mathrm{mg} 4 \text { times daily } \\
\text { Control: placebo } \\
\text { Duration: } 40 \text { weeks }\end{array}$ \\
\hline Outcomes & $\begin{array}{l}\text { Primary: geometric mean TWD and PFWD } \\
\text { Secondary: side effects }\end{array}$ \\
\hline Notes & $\begin{array}{l}\text { Treadmill protocol: } 3 \mathrm{~km} / \mathrm{h} \text { at } 12 \% \text { inclination } \\
\text { Geometric mean PFWD and TWD expressed in metres only }\end{array}$ \\
\hline
\end{tabular}

\section{Risk of bias}


Cesarone 2002b (Continued)

\section{Bias Authors' judgement Support for judgement}

Random sequence genera- Unclear risk States 'randomised into two treatment plans'; no further information provided tion (selection bias)

\begin{tabular}{ll}
\hline $\begin{array}{l}\text { Allocation concealment } \\
\text { (selection bias) }\end{array}$ & Unclear risk mentioned \\
\hline
\end{tabular}

\begin{tabular}{|c|c|c|}
\hline $\begin{array}{l}\text { Blinding of participants } \\
\text { and personnel (perfor- } \\
\text { mance bias) }\end{array}$ & Unclear risk & $\begin{array}{l}\text { States 'double blind' and 'pentoxifylline and equivalent placebo were adminis- } \\
\text { tered'; no other information provided }\end{array}$ \\
\hline
\end{tabular}

\begin{tabular}{|c|c|c|}
\hline $\begin{array}{l}\text { Blinding of outcome as- } \\
\text { sessment (detection bias) } \\
\text { All outcomes }\end{array}$ & Unclear risk & Not mentioned \\
\hline $\begin{array}{l}\text { Incomplete outcome data } \\
\text { (attrition bias) } \\
\text { All outcomes }\end{array}$ & Unclear risk & No information provided on dropouts \\
\hline $\begin{array}{l}\text { Selective reporting (re- } \\
\text { porting bias) }\end{array}$ & Unclear risk & Protocol not available; insufficient information available to permit judgement \\
\hline Other bias & Low risk & Study appears free of other bias \\
\hline
\end{tabular}

Chacon-Quevedo 1994

\begin{tabular}{|c|c|}
\hline Methods & $\begin{array}{l}\text { Study design: double-blinded, randomised } \\
\text { Country: Spain } \\
\text { Setting: single centre } \\
\text { Intention-to-treat: not mentioned }\end{array}$ \\
\hline Participants & $\begin{array}{l}\text { Number of participants randomly assigned: } 45 \text { (15 in each arm) } \\
\text { Number of participants analysed: } 45 \\
\text { Exclusions post randomisation: none } \\
\text { Losses to follow-up: none } \\
\text { Age: } 61 \pm 8 \text { years } \\
\text { Sex: all men } \\
\text { Inclusion criteria: PAD Fontaine stage II } \\
\text { Exclusion criteria: not mentioned }\end{array}$ \\
\hline Interventions & $\begin{array}{l}\text { Treatment: pentoxifylline, } 1200 \mathrm{mg} / \mathrm{d} \\
\text { Control: } \\
\text { - Buflomedil, } 600 \mathrm{mg} / \mathrm{d} \\
\text { - Nifedipine, } 600 \mathrm{mg} / \mathrm{d}\end{array}$ \\
\hline
\end{tabular}


Chacon-Quevedo 1994 (Continued)

Duration: 90 days

\begin{tabular}{ll}
\hline Outcomes & Primary: mean PFWD, TWD \\
& Secondary: $\mathrm{ABI}$ \\
\hline Notes & Treadmill protocol: $3 \mathrm{~km} / \mathrm{h}$ at $10 \%$ inclination \\
& Mean PFWD and TWD expressed in metres only \\
\hline
\end{tabular}

\section{Risk of bias}

\begin{tabular}{|c|c|c|}
\hline Bias & Authors' judgement & Support for judgement \\
\hline $\begin{array}{l}\text { Random sequence genera- } \\
\text { tion (selection bias) }\end{array}$ & Unclear risk & $\begin{array}{l}\text { States 'patients were divided randomly into three treatment groups'; no other } \\
\text { information provided }\end{array}$ \\
\hline $\begin{array}{l}\text { Allocation concealment } \\
\text { (selection bias) }\end{array}$ & Unclear risk & Not mentioned \\
\hline $\begin{array}{l}\text { Blinding of participants } \\
\text { and personnel (perfor- } \\
\text { mance bias) } \\
\text { All outcomes }\end{array}$ & Unclear risk & Insufficient information provided to permit judgement \\
\hline $\begin{array}{l}\text { Blinding of outcome as- } \\
\text { sessment (detection bias) } \\
\text { All outcomes }\end{array}$ & Unclear risk & Insufficient information provided to permit judgement \\
\hline $\begin{array}{l}\text { Incomplete outcome data } \\
\text { (attrition bias) } \\
\text { All outcomes }\end{array}$ & Low risk & No incomplete outcome data \\
\hline $\begin{array}{l}\text { Selective reporting (re- } \\
\text { porting bias) }\end{array}$ & Unclear risk & Insufficient information provided to permit judgement \\
\hline Other bias & Unclear risk & Insufficient information provided to permit judgement \\
\hline
\end{tabular}

Ciocon 1997

\begin{tabular}{ll}
\hline Methods & Study design: randomised \\
Country: USA & Setting: 2 centres \\
Intention-to-treat: not mentioned \\
\hline Pumber of participants randomly assigned: 90 \\
Number of participants analysed: 90 (45 in each group) \\
Exclusions post randomisation: not mentioned \\
Losses to follow-up: not mentioned \\
Age: $79 \pm 3.5$ years \\
Sex: M:F: pentoxifylline: $10: 34$, aspirin: $12: 34$ \\
\hline
\end{tabular}


Ciocon 1997 (Continued)

Inclusion criteria: age $\geq 65$ years; ankle-to-arm pressure < 0.8 ; not taken aspirin/pentoxifylline over previous 6 months; experienced leg claudication

Exclusion criteria: took aspirin or pentoxifylline in previous 6 months; leg rest pain; vascular surgery; co-existing stable angina, severe osteoarthritis, peripheral neuropathy, leg surgery within previous 6 months; ankle-to-arm pressure ratio $>0.8$

Interventions
Control: aspirin, $325 \mathrm{mg}$ daily
Duration: 6 weeks

\begin{tabular}{ll}
\hline Outcomes & Primary: TWD \\
& Secondary: ABI \\
\hline Notes & Treadmill protocol: not specified \\
& TWD expressed in metres only
\end{tabular}

\section{Risk of bias}

Bias Authors' judgement Support for judgement

Random sequence genera- Unclear risk States 'were randomly assigned to'; no further information provided tion (selection bias)

\begin{tabular}{|c|c|c|}
\hline $\begin{array}{l}\text { Allocation concealment } \\
\text { (selection bias) }\end{array}$ & Unclear risk & Not mentioned \\
\hline $\begin{array}{l}\text { Blinding of participants } \\
\text { and personnel (perfor- } \\
\text { mance bias) } \\
\text { All outcomes }\end{array}$ & High risk & Different treatments: pentoxifylline twice daily, aspirin once daily \\
\hline $\begin{array}{l}\text { Blinding of outcome as- } \\
\text { sessment (detection bias) } \\
\text { All outcomes }\end{array}$ & Unclear risk & Not mentioned \\
\hline $\begin{array}{l}\text { Incomplete outcome data } \\
\text { (attrition bias) } \\
\text { All outcomes }\end{array}$ & Low risk & No missing outcome data \\
\hline $\begin{array}{l}\text { Selective reporting (re- } \\
\text { porting bias) }\end{array}$ & Unclear risk & Protocol not available; insufficient information available to permit judgement \\
\hline Other bias & Low risk & Study appears free of other bias \\
\hline
\end{tabular}

\section{Creager 2008}

Study design: double-blinded, randomised
Country: USA
Setting: 32 centres
Intention-to-treat: not mentioned: yes


Creager 2008 (Continued)

Participants
Number of participants randomly assigned: 430

Number of participants analysed: 370

Exclusions post randomisation: none

Losses to follow-up: 60

Age: 67 years

Sex: M:F: 349:81

Inclusion criteria: age $\geq 40$ years; Fontaine stage II; stable claudication for $\geq 3$ months despite standard care; absolute claudication distance between 50 and $800 \mathrm{~m} ; \mathrm{ABPI} \leq 0.90$ in symptomatic leg and $>20 \%$ fall in ABPI within 1 minute following cessation of exercise; in non-compressible vessels, toe-brachial index at rest < 0.70; final inclusion criteria after run-in phase: absolute claudication distance within $20 \%$ of ACD on previous measurements before run-in phase; compliance with drug of $80 \%$ to $120 \%$

Exclusion criteria: ischaemic rest pain, ulcers, gangrene (Fontaine stage III and IV); evidence of non-atherosclerotic PAD; peripheral neuropathy impairing walking; revascularisation procedures within preceding 3 months; sympathectomy within 6 months; type 1 diabetes mellitus; myocardial infarction or major cardiac surgery within 3 months; unstable angina; heart failure; patients receiving low molecular weight heparin and warfarin in combination with aspirin, or any other drug for intermittent claudication

Interventions
Control
- Placebo
- Iloprost $50 \mu \mathrm{g} \mathrm{bd}$
- Iloprost $100 \mu \mathrm{g} \mathrm{bd}$
- Iloprost $150 \mu \mathrm{g} \mathrm{bd}$
Duration: 6 months

Outcomes

Primary: TWD expressed as \% change from baseline to follow-up

Secondary: PFWD, quality of life (WIQ and SF36), side effects
Treadmill protocol: $3.2 \mathrm{~km} / \mathrm{h}$ at $0 \%$ gradient, increased by $2 \%$ every 2 minutes

TWD expressed in metres at baseline and \% change at follow-up

\section{Risk of bias}

\begin{tabular}{lll}
\hline Bias & Authors' judgement & Support for judgement \\
\hline $\begin{array}{l}\text { Random sequence genera- } \\
\text { tion (selection bias) }\end{array}$ & Unclear risk & States 'randomised placebo controlled'; no further information provided \\
\hline $\begin{array}{l}\text { Allocation concealment } \\
\text { (selection bias) }\end{array}$ & Unclear risk & Not mentioned \\
\hline $\begin{array}{l}\text { Blinding of participants } \\
\text { and personnel (perfor- } \\
\text { mance bias) } \\
\begin{array}{l}\text { All outcomes } \\
\text { Blinding of outcome as- } \\
\text { sessment (detection bias) }\end{array}\end{array}$ & Low risk & Treatments appropriately blinded for participants and personnel \\
\hline
\end{tabular}


Creager 2008 (Continued)

All outcomes

\begin{tabular}{|c|c|c|}
\hline $\begin{array}{l}\text { Incomplete outcome data } \\
\text { (attrition bias) }\end{array}$ & Unclear risk & $\begin{array}{l}\text { Unclear why participants stopped medication; unclear whether data present } \\
\text { ed represent intention-to-treat or per-protocol analysis }\end{array}$ \\
\hline
\end{tabular}

All outcomes

\begin{tabular}{lll}
\hline $\begin{array}{l}\text { Selective reporting (re- } \\
\text { porting bias) }\end{array}$ & Unclear risk & Insufficient information to permit judgement \\
\hline Other bias & Unclear risk & Sponsor: Berlex Pharmaceuticals Inc.
\end{tabular}

\section{Dawson 2000}

\begin{tabular}{|c|c|}
\hline Methods & $\begin{array}{l}\text { Study design: double-blinded, randomised } \\
\text { Country: USA } \\
\text { Setting: multi-centre - } 54 \text { centres } \\
\text { Intention-to-treat: yes }\end{array}$ \\
\hline Participants & $\begin{array}{l}\text { Number of participants randomly assigned: } 699 \\
\text { Number of participants analysed: } 698 \\
\text { Exclusions post randomisation: } 1 \\
\text { Losses to follow-up: } 159 \\
\text { Age: } 66 \pm 9 \text { years for all groups } \\
\text { Sex: cilostazol: } 172 \text { male, pentoxifylline: } 181 \text { male, placebo: } 176 \text { male } \\
\text { Inclusion criteria: > } 6 \text { months of symptoms with no substantial change within previous } 3 \text { months; base- } \\
\text { line claudication distance > } 53.6 \text { m (1 minute on treadmill protocol); baseline walking distance < 537.6 } \\
\text { m (10 minutes on treadmill protocol); peripheral arterial disease diagnosis confirmed by either a rest- } \\
\text { ing ABI } \leq 0.9 \text { and a } \geq 10 \text { mmHg decrease in ankle pressure measured } 1 \text { minute after walking to maximal } \\
\text { walking distance or a } \geq 20 \text { mmHg decrease in post-exercise ankle pressure in symptomatic extremity } \\
\text { Exclusion criteria: Buerger's disease; critical ischaemia (II or III chronic lower extremity ischaemia); low- } \\
\text { er extremity arterial reconstruction (surgical or endovascular) or sympathectomy within previous } 3 \\
\text { months; other conditions limiting exercise capacity; other medical conditions limiting participation; } \\
\text { prior use of cilostazol or pentoxifylline within } 30 \text { days of start date; }>20 \% \text { variation in maximal walking } \\
\text { distance; use of anticoagulants or antiplatelet agents except for aspirin at a dose } \leq 81 \text { mg/d }\end{array}$ \\
\hline
\end{tabular}

Treatment: oral pentoxifylline, $400 \mathrm{mg} 3$ times daily
Control
- Placebo
- Cilostazol, $100 \mathrm{mg}$ twice daily plus 1 identical placebo tablet
Duration: 24 weeks

Outcomes

Primary: mean PFWD, TWD

Secondary: $\mathrm{ABI}$, side effects and QoL (SF36, WIQ)

Notes

Treadmill protocol: $3.2 \mathrm{~km} / \mathrm{h}$ at $0 \%$ inclination, increased by $3.5 \%$ every 3 minutes 


\section{Risk of bias}

\begin{tabular}{|c|c|c|}
\hline Bias & Authors' judgement & Support for judgement \\
\hline $\begin{array}{l}\text { Random sequence genera- } \\
\text { tion (selection bias) }\end{array}$ & Low risk & $\begin{array}{l}\text { Stratified by clinical centre and patients assigned to } 1 \text { of } 3 \text { treatment regimes } \\
\text { within each centre using permuted block design }\end{array}$ \\
\hline $\begin{array}{l}\text { Allocation concealment } \\
\text { (selection bias) }\end{array}$ & Low risk & $\begin{array}{l}\text { 'Interactive voice randomization that blinded the investigator, patients and } \\
\text { sponsor from treatment assignment' }\end{array}$ \\
\hline $\begin{array}{l}\text { Blinding of participants } \\
\text { and personnel (perfor- } \\
\text { mance bias) } \\
\text { All outcomes }\end{array}$ & Low risk & Treatments appropriately blinded for participants and personnel \\
\hline $\begin{array}{l}\text { Blinding of outcome as- } \\
\text { sessment (detection bias) } \\
\text { All outcomes }\end{array}$ & Unclear risk & Not mentioned \\
\hline $\begin{array}{l}\text { Incomplete outcome data } \\
\text { (attrition bias) } \\
\text { All outcomes }\end{array}$ & Low risk & No missing outcome data \\
\hline $\begin{array}{l}\text { Selective reporting (re- } \\
\text { porting bias) }\end{array}$ & Unclear risk & Protocol not available; insufficient information available to permit judgement \\
\hline Other bias & Unclear risk & $\begin{array}{l}\text { 'Supported by Otsuka America Pharmaceuticals Inc., a US affiliate of the man- } \\
\text { ufacturer of cilostazol' }\end{array}$ \\
\hline
\end{tabular}

\section{De Sanctis 2002a}

$\begin{array}{ll}\text { Methods } & \text { Study design: double-blinded, randomised } \\ \text { Country: USA } \\ \text { Setting: } 5 \text { centres } \\ \text { Intention-to-treat: yes }\end{array}$

Exclusions post randomisation: 19

Losses to follow-up: none

Age: pentoxifylline: $63 \pm 4$ years, placebo: $62 \pm 3$ years

Sex: M:F: pentoxifylline: $36: 20$, placebo: $24: 21$

Inclusion criteria: severe intermittent claudication with total walking distance between 50 and 200 $\mathrm{m}$; intermittent claudication $>4$ months; resting Doppler ankle-brachial index $<0.8$; decrease in ankle pressure $>15 \mathrm{mmHg}$ after standard exercise test on treadmill; age between 45 and 75 years; documentation of arterial stenoses, plaques and flow reduction due to arteriosclerosis by colour-duplex imaging 
De Sanctis 2002a (Continued)

Exclusion criteria: presence of indication for revascularisation or angioplasty procedures; angina pectoris or myocardial ischaemia on effort at $80 \%$ of target heart rate; previous coronary or vascular surgery or angioplasty; aneurysms, congestive heart failure NYHA III-IV, renal failure (creatinine > $2 \mathrm{mg}$ / $\mathrm{dL}$ ), IDDM II; change $> \pm 25 \%$ during 2-week run in period; arthritis or other pulmonary, cardiac or neoplastic disease or inflammatory or immunologic disease

\begin{tabular}{ll}
\hline Interventions & Treatment: oral pentoxifylline, $600 \mathrm{mg} 3$ times daily \\
& Control: placebo \\
& Duration: 12 months \\
\hline Outcomes & Primary: mean TWD \\
& Secondary: none \\
\hline Notes & Treadmill protocol: $3 \mathrm{~km} / \mathrm{h}$ at $12 \%$ inclination \\
& Mean TWD expressed in metres only \\
& Participants also took 300 mg antiplatelets as part of study treatment \\
\hline
\end{tabular}

\section{Risk of bias}

\begin{tabular}{lll}
\hline Bias & Authors' judgement & Support for judgement \\
\hline $\begin{array}{l}\text { Random sequence genera- } \\
\text { tion (selection bias) }\end{array}$ & Unclear risk & $\begin{array}{l}\text { States 'patients were randomised into two treatment plans'; no other informa- } \\
\text { tion provided }\end{array}$ \\
\hline $\begin{array}{l}\text { Allocation concealment } \\
\text { (selection bias) }\end{array}$ & Unclear risk & Not mentioned \\
\hline
\end{tabular}

Blinding of participants Unclear risk Insufficient information provided to permit judgement

and personnel (perfor-

mance bias)

All outcomes

\begin{tabular}{lll}
\hline $\begin{array}{l}\text { Blinding of outcome as- } \\
\text { sessment (detection bias) } \\
\text { All outcomes }\end{array}$ & Unclear risk & Not mentioned \\
\hline $\begin{array}{l}\text { Incomplete outcome data } \\
\text { (attrition bias) } \\
\text { All outcomes }\end{array}$ & Unclear risk & No information on dropouts provided other than due to low compliance \\
\hline $\begin{array}{l}\text { Selective reporting (re- } \\
\text { porting bias) }\end{array}$ & Unclear risk & No information on dropouts provided other than due to low compliance \\
\hline $\begin{array}{l}\text { Other bias } \\
\text { Unclear risk }\end{array}$ & $\begin{array}{l}\text { Pentoxifylline dose unclear; study authors report both } 1600 \mathrm{mg} \text { and } 1800 \mathrm{mg} . \\
\text { Assumed } 1800 \mathrm{mg}(3 \times 600 \mathrm{mg}) \text { is actual treatment }\end{array}$ \\
\hline
\end{tabular}

\section{De Sanctis 2002b}

Study design: double-blinded, randomised
Country: USA
Setting: 5 centres


De Sanctis 2002b (Continued)

Intention-to-treat: no

\begin{tabular}{|c|c|}
\hline \multirow[t]{8}{*}{ Participants } & Number of participants randomly assigned: 194 \\
\hline & Number of participants analysed: 135 (75 pentoxifylline, 60 placebo) \\
\hline & Exclusions post randomisation: 59 \\
\hline & Losses to follow-up: none \\
\hline & Age: pentoxifylline: $62 \pm 9$ years, placebo: $61 \pm 8$ years \\
\hline & Sex: M:F: pentoxifylline: $46: 29$, placebo: $28: 22$ \\
\hline & $\begin{array}{l}\text { Inclusion criteria: intermittent claudication with total walking distance }>400 \mathrm{~m} \text {; claudication }>3 \\
\text { months; Doppler ankle-brachial index }<0.8 \text {; decrease in ankle pressure }>20 \mathrm{~mm} \mathrm{Hg} \text { after standard ex- } \\
\text { ercise test on treadmill; age between } 50 \text { and } 65 \text { years; arterial stenoses, plaques and flow reduction on } \\
\text { colour duplex imaging }\end{array}$ \\
\hline & $\begin{array}{l}\text { Exclusion criteria: presence of Indication for revascularisation or angioplasty; angina or myocardial is- } \\
\text { chaemia on effort; previous coronary or vascular surgery or angioplasty, aneurysms, congestive heart } \\
\text { failure NYHA III/IV, renal failure (creatinine }>2 \mathrm{mg} / \mathrm{dL} \text { ), IDDM II; arthritis; other pulmonary cardiac neo- } \\
\text { plastic disease or inflammatory or immunologic disease }\end{array}$ \\
\hline \multirow[t]{3}{*}{ Interventions } & Treatment: oral pentoxifylline, $600 \mathrm{mg} 3$ times daily \\
\hline & Control: placebo \\
\hline & Duration: 12 months \\
\hline \multirow[t]{2}{*}{ Outcomes } & Primary: mean TWD \\
\hline & Secondary: side effects \\
\hline \multirow[t]{3}{*}{ Notes } & Treadmill protocol: $3 \mathrm{~km} / \mathrm{h}$ at $12 \%$ inclination \\
\hline & Mean TWD expressed in metres only \\
\hline & Participants also took $300 \mathrm{mg}$ antiplatelets as part of study treatment \\
\hline
\end{tabular}

\section{Risk of bias}

Bias Authors' judgement Support for judgement

Random sequence genera- Unclear risk States 'patients were randomised into two treatment plans'; no other information (selection bias) tion provided

\begin{tabular}{lll}
\hline $\begin{array}{l}\text { Allocation concealment } \\
\text { (selection bias) }\end{array}$ & Unclear risk & Not mentioned \\
\hline $\begin{array}{l}\text { Blinding of participants } \\
\text { and personnel (perfor- } \\
\text { mance bias) }\end{array}$ & Unclear risk & Insufficient information provided to permit judgement \\
$\begin{array}{l}\text { All outcomes } \\
\text { Blinding of outcome as- } \\
\text { sessment (detection bias) } \\
\text { All outcomes }\end{array}$ & Unclear risk & Not mentioned \\
\hline
\end{tabular}

Incomplete outcome data Unclear risk $\quad$ No information on dropouts provided other than due to low compliance
(attrition bias)


De Sanctis 2002b (Continued)

All outcomes

Selective reporting (re- Unclear risk $\quad$ No information on dropouts provided other than due to low compliance
porting bias)

\begin{tabular}{|c|c|c|}
\hline Other bias & Unclear risk & $\begin{array}{l}\text { Pentoxifylline dose unclear; study authors report both } 1600 \mathrm{mg} \text { and } 1800 \mathrm{mg} \text {. } \\
\text { Assumed } 1800 \mathrm{mg}(3 \times 600 \mathrm{mg}) \text { is actual treatment }\end{array}$ \\
\hline
\end{tabular}

\section{Di Perri 1983}

\begin{tabular}{l} 
Study design: double-blinded, randomised. Cross-over after 8 weeks \\
Country: Italy \\
Setting: single centre \\
Intention-to-treat: not mentioned \\
\hline
\end{tabular}

Number of participants randomly assigned: 24
Number of participants analysed: 24
Exclusions post randomisation: none
Losses to follow-up: none
Age: 59.3 years in both groups (range 40 to 71 years)
Sex: group 1: 9 males, 3 females, group 2: 10 males, 2 females
Inclusion criteria: walking capacity between 100 and 400 m; Fontaine II
Exclusion criteria: pain at rest, paraesthesia and skin lesions; diabetes mellitus; severe hypertension;
congestive heart failure

Interventions Treatment: oral pentoxifylline, $400 \mathrm{mg}$ twice daily

Control: placebo

Duration: 8 weeks and cross-over after 2-week washout phase

\begin{tabular}{ll}
\hline Outcomes & Primary: mean TWD \\
& Secondary: none \\
\hline Notes & Treadmill protocol: 120 steps/min at horizontal level \\
& Mean TWD expressed in metres only \\
& Participants stopped smoking at the start of the study \\
& Study authors reported a carryover effect that was not eliminated by the washout phase
\end{tabular}

\section{Risk of bias}

\begin{tabular}{lll}
\hline Bias & Authors' judgement & Support for judgement \\
\hline $\begin{array}{l}\text { Random sequence genera- } \\
\text { tion (selection bias) }\end{array}$ & Unclear risk & $\begin{array}{l}\text { States 'randomly allotted into two groups to received either treatment A or } \\
\text { treatment B'; no other information provided }\end{array}$ \\
\hline
\end{tabular}


Di Perri 1983 (Continued)

\begin{tabular}{|c|c|c|}
\hline $\begin{array}{l}\text { Allocation concealment } \\
\text { (selection bias) }\end{array}$ & Unclear risk & Not mentioned \\
\hline $\begin{array}{l}\text { Blinding of participants } \\
\text { and personnel (perfor- } \\
\text { mance bias) } \\
\text { All outcomes }\end{array}$ & Low risk & $\begin{array}{l}\text { Pentoxifylline and placebo were of identical appearance and were provided as } \\
1 \text { tablet } 3 \text { times a day for each treatment }\end{array}$ \\
\hline $\begin{array}{l}\text { Blinding of outcome as- } \\
\text { sessment (detection bias) } \\
\text { All outcomes }\end{array}$ & Unclear risk & Not mentioned \\
\hline $\begin{array}{l}\text { Incomplete outcome data } \\
\text { (attrition bias) } \\
\text { All outcomes }\end{array}$ & Unclear risk & Adverse events reported only in the summary, not in the main paper \\
\hline $\begin{array}{l}\text { Selective reporting (re- } \\
\text { porting bias) }\end{array}$ & Unclear risk & Adverse events reported only in the summary, not in the main paper \\
\hline Other bias & Unclear risk & $\begin{array}{l}\text { Authors reported a carryover effect that was not eliminated by the washout } \\
\text { phase }\end{array}$ \\
\hline
\end{tabular}

Donaldson 1984

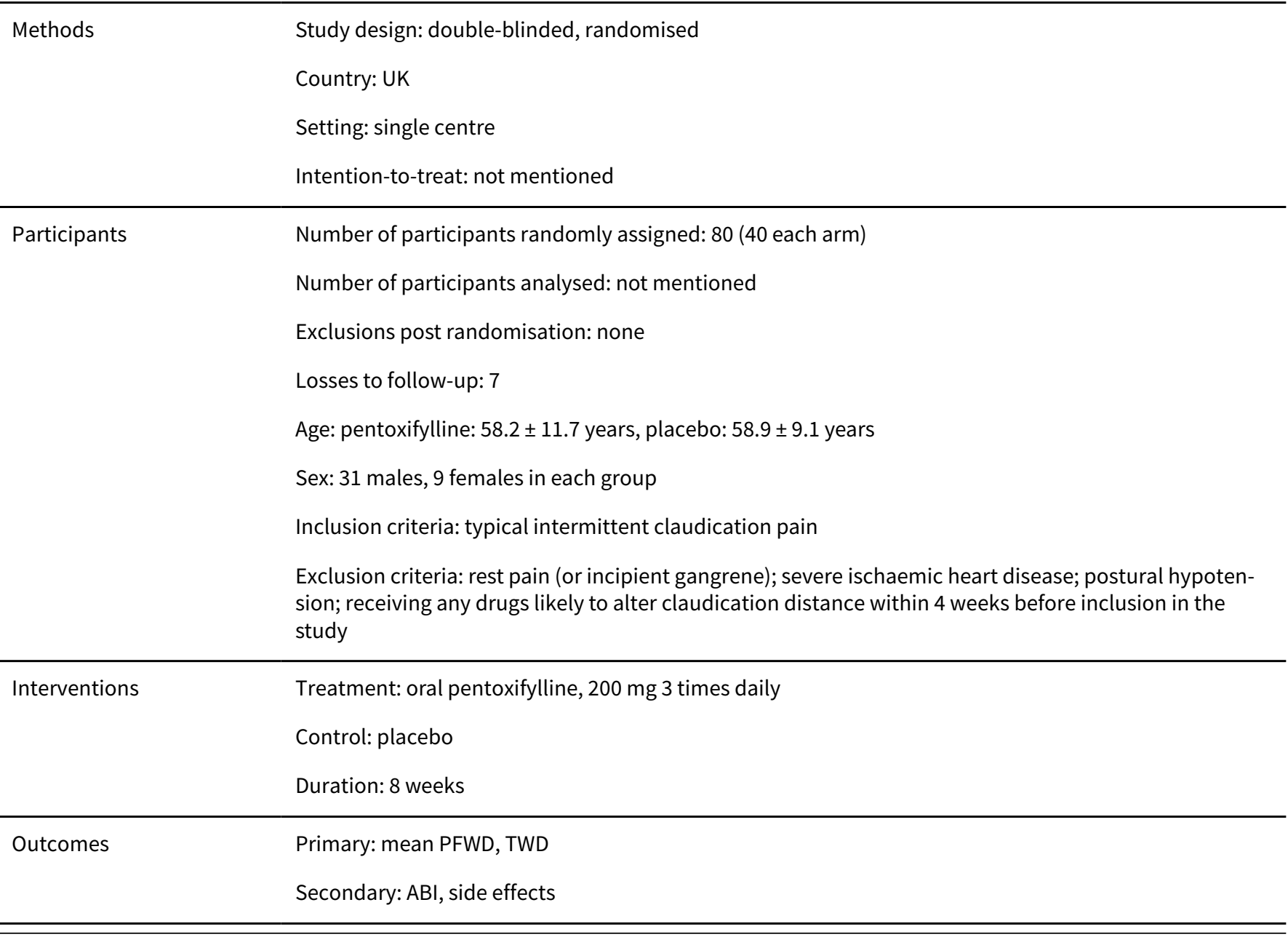


Donaldson 1984 (Continued)
Notes
Treadmill protocol: $4 \mathrm{~km} / \mathrm{h}$ at $0 \%$ inclination
Mean PFWD and TWD expressed in metres only

\section{Risk of bias}

\begin{tabular}{|c|c|c|}
\hline Bias & Authors' judgement & Support for judgement \\
\hline $\begin{array}{l}\text { Random sequence genera- } \\
\text { tion (selection bias) }\end{array}$ & Unclear risk & States 'randomised'; no other information provided \\
\hline $\begin{array}{l}\text { Allocation concealment } \\
\text { (selection bias) }\end{array}$ & Unclear risk & Not mentioned \\
\hline $\begin{array}{l}\text { Blinding of participants } \\
\text { and personnel (perfor- } \\
\text { mance bias) } \\
\text { All outcomes }\end{array}$ & Unclear risk & Insufficient information provided to permit judgement \\
\hline $\begin{array}{l}\text { Blinding of outcome as- } \\
\text { sessment (detection bias) } \\
\text { All outcomes }\end{array}$ & Unclear risk & Not mentioned \\
\hline $\begin{array}{l}\text { Incomplete outcome data } \\
\text { (attrition bias) } \\
\text { All outcomes }\end{array}$ & Low risk & No incomplete outcome data \\
\hline $\begin{array}{l}\text { Selective reporting (re- } \\
\text { porting bias) }\end{array}$ & Unclear risk & Protocol not available; insufficient information available to permit judgement \\
\hline Other bias & Low risk & Study appears free of other bias \\
\hline
\end{tabular}

Ernst 1992

$\begin{array}{ll}\text { Methods } & \text { Study design: RCT } \\ \text { Country: Austria, Hungary, Germany } \\ \text { Setting: } 3 \text { centres } \\ \text { Intention-to-treat: not mentioned } \\ \text { Number of participants randomly assigned: } 40 \text { (20 each arm) } \\ \text { Number of participants analysed: } 40 \\ \text { Exclusions post randomisation: none } \\ \text { Losses to follow-up: none } \\ \text { Age: pentoxifylline: } 53.3 \pm 9.6 \text { years, placebo: } 55.9 \pm 11.9 \text { years } \\ \text { Sex: M:F: pentoxifylline: } 15: 5 \text {, placebo: } 19: 1 \\ \text { Inclusion criteria: PAD stage II by clinical diagnosis, doppler pressures and angiography; pain-free walk- } \\ \text { ing distance < 200 m; stable } \geq 3 \text { months } \\ \text { Exclusion criteria: claudication due to non-vascular reasons; pre-treatment with drugs considered to } \\ \text { be "rheologically active" }\end{array}$


Ernst 1992 (Continued)

\begin{tabular}{ll} 
Interventions & Treatment: oral pentoxifylline, $600 \mathrm{mg}$ twice daily \\
& Control: placebo \\
& Duration: 12 weeks \\
\hline Outcomes & Primary: mean TWD and PFWD \\
& Secondary: none \\
\hline Notes & Treadmill protocol: not specified \\
& Mean PFWD and TWD expressed in metres only \\
Both groups received a supervised exercise programme for 1 hour, twice a week
\end{tabular}

\section{Risk of bias}

\begin{tabular}{lll}
\hline Bias & Authors' judgement & Support for judgement \\
\hline $\begin{array}{l}\text { Random sequence genera- } \\
\text { tion (selection bias) }\end{array}$ & Unclear risk & States 'randomised'; no other information provided \\
\hline $\begin{array}{l}\text { Allocation concealment } \\
\text { (selection bias) }\end{array}$ & Unclear risk & Not mentioned \\
\hline $\begin{array}{l}\text { Blinding of participants } \\
\text { and personnel (perfor- } \\
\text { mance bias) }\end{array}$ & Unclear risk & Insufficient information provided to permit judgement \\
All outcomes & \\
\hline $\begin{array}{l}\text { Blinding of outcome as- } \\
\text { sessment (detection bias) }\end{array}$ & Unclear risk & Not mentioned \\
All outcomes & \\
\hline $\begin{array}{l}\text { Incomplete outcome data } \\
\text { (attrition bias) } \\
\text { All outcomes }\end{array}$ & Low risk & No incomplete outcome data \\
\hline $\begin{array}{l}\text { Selective reporting (re- } \\
\text { porting bias) }\end{array}$ & Unclear risk & Protocol not available; insufficient information available to permit judgement \\
\hline \begin{tabular}{l} 
Other bias \\
\hline
\end{tabular} & Low risk & Study appears free of other bias \\
\hline
\end{tabular}

\section{Gallus 1985}

Methods Study design: double-blinded, randomised. Cross-over after 8 weeks; no washout period

Country: Australia

Setting: single centre

Intention-to-treat: not mentioned

$\begin{array}{ll}\text { Participants } & \text { Number of participants randomly assigned: } 47 \\ \text { Number of participants analysed: } 38 \text { (19 in each group) }\end{array}$


Exclusions post randomisation: 9

Losses to follow-up: none

Age: group A: 68 years, group B: 66 years

Sex: group A: 17 males, 2 females, group B: 14 males, 5 females

Inclusion criteria: stable claudication distance > 6 months; presence of peripheral vascular disease documented through clinical examination by vascular surgeon and supplemented by angiography or noninvasive testing; age > 50 years; pledge not to change smoking habits during trial; informed consent

Exclusion criteria: vascular surgery or sympathectomy within previous 6 months; ischaemic leg ulcer or rest pain; exercise tolerance limited by conditions other than peripheral vascular disease; treatment with lipid-lowering or antiplatelet drugs

Treatment: $400 \mathrm{mg}$ twice daily for 1 week, then $400 \mathrm{mg} 3$ times daily for 7 weeks
Control: placebo
Duration: 8 weeks, then cross-over for another 8 weeks; no washout phase

Outcomes Primary: geometric mean TWD and PFWD

Secondary: $\mathrm{ABI}$

\begin{tabular}{ll}
\hline Notes & Treadmill protocol: $4 \mathrm{~km} / \mathrm{h}$ at $10 \%$ inclination \\
& Geometric mean PFWD and TWD expressed in metres only
\end{tabular}

\section{Risk of bias}

\begin{tabular}{|c|c|c|}
\hline Bias & Authors' judgement & Support for judgement \\
\hline $\begin{array}{l}\text { Random sequence genera- } \\
\text { tion (selection bias) }\end{array}$ & Unclear risk & 'A random number sequence was used to form the two treatment groups' \\
\hline $\begin{array}{l}\text { Allocation concealment } \\
\text { (selection bias) }\end{array}$ & Unclear risk & Not mentioned \\
\hline $\begin{array}{l}\text { Blinding of participants } \\
\text { and personnel (perfor- } \\
\text { mance bias) } \\
\text { All outcomes }\end{array}$ & Low risk & $\begin{array}{l}\text { Participants and personnel blinded from allocation and held by hospital phar- } \\
\text { macy }\end{array}$ \\
\hline $\begin{array}{l}\text { Blinding of outcome as- } \\
\text { sessment (detection bias) } \\
\text { All outcomes }\end{array}$ & Low risk & 'Results were withheld from investigators during the study' \\
\hline $\begin{array}{l}\text { Incomplete outcome data } \\
\text { (attrition bias) } \\
\text { All outcomes }\end{array}$ & Low risk & No incomplete outcome data \\
\hline $\begin{array}{l}\text { Selective reporting (re- } \\
\text { porting bias) }\end{array}$ & Unclear risk & Protocol not available; insufficient information available to permit judgement \\
\hline Other bias & Low risk & Study appears free of other bias \\
\hline
\end{tabular}


Hepp 1992

Study design: double-blinded, randomised
Country: Germany
Setting: 9 centres
Intention-to-treat: not mentioned
Number of participants randomly assigned: 195 (98 pentoxifylline, 97 PGE1)
Number of participants analysed: 195
Exclusions post randomisation: none
Losses to follow-up: none
Age: 65 years
Sex: M:F: $2.8: 1$
Inclusion criteria: pain-free walking distance 50 to 200 m; stable stadium Fontaine IIb for 6 months; di-
agnosis of stenosis through digital substraction angiography or conventional angiography of lower
limbs; signing an informed consent form; variance of walking distance at beginning < 20\%
Exclusion criteria: pregnancy; present heart failure; kidney failure; pre-stenosis (e.g. stenosis of the aor-
ta abdominalis or iliacal arteries); necrosis or rest pain; pulmonary insufficiency; arthrosis; myocardial
infarction within previous 6 months; orthostatic dysregulation and collapsing patients; severe cardiac
rhythm problems; epilepsy

\begin{tabular}{ll}
\hline Interventions & Treatment: intravenous pentoxifylline, 200 mg twice daily \\
& Control: intravenous PGE1, $400 \mathrm{mg}$ twice daily \\
& Duration: 4 weeks \\
\hline Outcomes & Primary: mean TWD and PFWD \\
& Secondary: side effects \\
\hline Notes & Treadmill protocol: not specified \\
& Mean PFWD and TWD expressed in metres only \\
\hline
\end{tabular}

\section{Risk of bias}

\begin{tabular}{lll}
\hline Bias & Authors' judgement & Support for judgement \\
\hline $\begin{array}{l}\text { Random sequence genera- } \\
\text { tion (selection bias) }\end{array}$ & Unclear risk & States 'randomisation list'; no other information provided \\
\hline $\begin{array}{l}\text { Allocation concealment } \\
\text { (selection bias) }\end{array}$ & Unclear risk & Not mentioned \\
\hline $\begin{array}{l}\text { Blinding of participants } \\
\text { and personnel (perfor- } \\
\text { mance bias) }\end{array}$ & Unclear risk & Reports 'blind', but no other information provided \\
All outcomes & \\
\hline $\begin{array}{l}\text { Blinding of outcome as- } \\
\text { sessment (detection bias) } \\
\text { All outcomes }\end{array}$ & Unclear risk & Not mentioned \\
\hline
\end{tabular}


Hepp 1992 (Continued)

Incomplete outcome data Low risk No incomplete outcome data
(attrition bias)

All outcomes

Selective reporting (re- Unclear risk $\quad$ Protocol not available; insufficient information available to permit judgement
porting bias)

\begin{tabular}{ll}
\hline Other bias $\quad$ Low risk $\quad$ Study appears free of other bias \\
\hline
\end{tabular}

Kiesewetter 1988

Study design: double-blinded, randomised
Country: Germany
Setting: single centre
Intention-to-treat: not mentioned

\begin{tabular}{|c|c|}
\hline Participants & $\begin{array}{l}\text { Number of participants randomly assigned: } 40 \text { ( } 20 \text { in each arm) } \\
\text { Number of participants analysed: } 38 \\
\text { Exclusions post randomisation: } 2 \\
\text { Losses to follow-up: none } \\
\text { Age: pentoxifylline: } 59.4 \pm 11.4 \text { years, placebo } 62.1 \pm 8.2 \text { years } \\
\text { Sex: } 11 \text { males, } 8 \text { females in each group } \\
\text { Inclusion criteria: Fontaine II; already trained patients; } 6 \text { months stadium Fontaine IIb; all patients fin- } \\
\text { ished } 3 \text { months of exercise training still max walking distance < } 300 \text { m; max walking distance variation } \\
\text { in the last } 2 \text { weeks (twice/wk) < } 30 \% \\
\text { Exclusion criteria: other causes for walking problems (e.g. arthrosis, Parkinson's disease); operative } \\
\text { therapy within previous } 3 \text { months (sympathectomy, vessel operations); myocardial infarction previous } \\
3 \text { months, also apoplexia; severe internistic diseases (e.g. heart, kidney or liver disease); polyneuropa- } \\
\text { thy }\end{array}$ \\
\hline Interventions & $\begin{array}{l}\text { Treatment: oral pentoxifylline, } 400 \text { mg } 3 \text { times daily } \\
\text { Control: placebo } \\
\text { Duration: } 8 \text { weeks }\end{array}$ \\
\hline Outcomes & $\begin{array}{l}\text { Primary: mean PFWD } \\
\text { Secondary: none }\end{array}$ \\
\hline Notes & $\begin{array}{l}\text { Treadmill protocol: not specified } \\
\text { Mean PFWD expressed in metres only }\end{array}$ \\
\hline Risk of bias & \\
\hline Bias & Authors' judgement Support for judgement \\
\hline
\end{tabular}


Kiesewetter 1988 (Continued)

Random sequence genera- Unclear risk States 'randomised list'; no other information provided tion (selection bias)

\begin{tabular}{lll}
\hline $\begin{array}{l}\text { Allocation concealment } \\
\text { (selection bias) }\end{array}$ & Unclear risk & Not mentioned \\
\hline $\begin{array}{l}\text { Blinding of participants } \\
\text { and personnel (perfor- } \\
\text { mance bias) } \\
\text { All outcomes }\end{array}$ & Low risk & $\begin{array}{l}\text { Tablets were identical and randomisation key was not known until end of } \\
\text { study }\end{array}$ \\
\hline $\begin{array}{l}\text { Blinding of outcome as- } \\
\text { sessment (detection bias) } \\
\text { All outcomes }\end{array}$ & Unclear risk & Not mentioned \\
\hline $\begin{array}{l}\text { Incomplete outcome data } \\
\text { (attrition bias) } \\
\text { All outcomes }\end{array}$ & Unclear risk & Insufficient information to permit judgement \\
\hline $\begin{array}{l}\text { Selective reporting (re- } \\
\text { porting bias) }\end{array}$ & High risk & \\
\hline \begin{tabular}{l} 
Other bias \\
\hline
\end{tabular} & Low risk & $\begin{array}{l}\text { TWD result reported in abstract but not mentioned in remainder as outcome } \\
\text { or result }\end{array}$ \\
\hline
\end{tabular}

\section{Lee 2001}

Study design: double-blinded, randomised
Country: Taiwan
Setting: single centre
Intention-to-treat: not mentioned

\section{Participants}

Number of participants randomly assigned: 50

Number of participants analysed: 50

Exclusions post randomisation: none

Losses to follow-up: none

Age: cilostazol: $66 \pm 9$ years, pentoxifylline: $68 \pm 5$ years, placebo: $69 \pm 6$ years

Sex: M:F: cilostazol: 14/3, pentoxifylline: 14/3, placebo: $14 / 2$

Inclusion criteria: > 40 years old; stable PAD for last 3 months; baseline max walking distance $>30 \mathrm{~m}$ and $<200 \mathrm{~m}$; variance $<20 \%$ in WMD in the 2 screening tests

Exclusion criteria: Buerger's disease; category II or III chronic lower limb ischaemia; arterial surgery/angioplasty or sympathectomy within previous 3 months

Interventions
$\begin{aligned} & \text { Control } \\ & \text { - Oral cilostazol, } 100 \mathrm{mg} \text { twice daily } \\ & \text { - Placebo }\end{aligned}$


Lee 2001 (Continued)

Duration: 8 weeks

\begin{tabular}{ll}
\hline Outcomes & Primary: mean TWD \\
& Secondary: ABI, side effects \\
\hline Notes & Treadmill protocol: $3.2 \mathrm{~km} / \mathrm{h}$ at $12.5 \%$ gradient \\
& Mean TWD expressed in metres only \\
\hline
\end{tabular}

\section{Risk of bias}

\begin{tabular}{|c|c|c|}
\hline Bias & Authors' judgement & Support for judgement \\
\hline $\begin{array}{l}\text { Random sequence genera- } \\
\text { tion (selection bias) }\end{array}$ & Low risk & $\begin{array}{l}\text { 'Randomised code number according to which sponsor supplied the study } \\
\text { drug' }\end{array}$ \\
\hline $\begin{array}{l}\text { Allocation concealment } \\
\text { (selection bias) }\end{array}$ & Low risk & Sealed envelopes \\
\hline $\begin{array}{l}\text { Blinding of participants } \\
\text { and personnel (perfor- } \\
\text { mance bias) } \\
\text { All outcomes }\end{array}$ & Low risk & $\begin{array}{l}\text { 'Special drug packaging was used to maintain the blindness of the treatment } \\
\text { code' }\end{array}$ \\
\hline $\begin{array}{l}\text { Blinding of outcome as- } \\
\text { sessment (detection bias) } \\
\text { All outcomes }\end{array}$ & Unclear risk & Not mentioned \\
\hline $\begin{array}{l}\text { Incomplete outcome data } \\
\text { (attrition bias) } \\
\text { All outcomes }\end{array}$ & Low risk & No incomplete outcome data \\
\hline $\begin{array}{l}\text { Selective reporting (re- } \\
\text { porting bias) }\end{array}$ & Unclear risk & Protocol not available; insufficient information available to permit judgement \\
\hline Other bias & Low risk & Study appears free of other bias \\
\hline
\end{tabular}

Lindgarde 1989

\begin{tabular}{ll}
\hline Methods & Study design: double-blinded, randomised \\
Country: Scandinavia \\
Setting: multi-centre \\
Intention-to-treat: yes \\
Number of participants randomly assigned: 150 (76 pentoxifylline, 74 placebo) \\
Number of participants analysed: 150 \\
Exclusions post randomisation: none \\
Losses to follow-up: none \\
Age: pentoxifylline: $65 \pm 7$ years, placebo: $64 \pm 8$ years \\
Sex: pentoxifylline: $79 \%$ males, placebo: $80 \%$ males
\end{tabular}


Inclusion criteria: $\geq 40$ years of age; moderate to severe COAD; initial claudication distance 50 to 200 $\mathrm{m}$; claudication history $>6$ months; variance of walking distance $<35 \%$ in the last 2 treadmill tests with baseline walking distance $<100 \mathrm{~m}$; variance of walking distance $<25 \%$ in the last 2 treadmill tests with baseline walking distance 101 to $200 \mathrm{~m}$

Exclusion criteria: complete occlusion of the aortoiliac segment, the femoral bifurcation or the popliteal artery without angiographically proven distal refilling of the respective segment; vascular reconstruction of sympathectomy within the past 12 months; peripheral neuropathy; Buerger's disease; marked post-phlebotic syndrome; diabetes; cardiac failure or severe rhythm disorders;

major infections; abnormal values for platelets; history of xanthine hypersensitivity; addiction to analgesics; malignant disease

\begin{tabular}{ll}
\hline Interventions & Treatment: oral pentoxifylline, $400 \mathrm{mg} 3$ times daily \\
& Control: placebo \\
& Duration: 6 months \\
\hline Outcomes & Primary: geometric means of $\%$ change in TWD and PFWD from baseline to follow-up \\
& Secondary: ABI, side effects \\
\hline Notes & Treadmill protocol: $3.2 \mathrm{~km} / \mathrm{h}$ at $12.5 \%$ inclination \\
& PFWD and TWD expressed as geometric mean of $\%$ change
\end{tabular}

\section{Risk of bias}

\begin{tabular}{lll}
\hline Bias & Authors' judgement & Support for judgement \\
\hline $\begin{array}{l}\text { Random sequence genera- } \\
\text { tion (selection bias) }\end{array}$ & Unclear risk & States 'randomisation stratified by centres'; no other information provided \\
\hline $\begin{array}{l}\text { Allocation concealment } \\
\text { (selection bias) }\end{array}$ & Unclear risk & Not mentioned \\
\hline $\begin{array}{l}\text { Blinding of participants } \\
\text { and personnel (perfor- } \\
\text { mance bias) }\end{array}$ & Low risk & $\begin{array}{l}\text { States 'During the double-blind period and according to a randomization plan, } \\
\text { pentoxifylline or matching placebo was administered t.i.d.' }\end{array}$ \\
\hline
\end{tabular}

\begin{tabular}{ll}
\hline Blinding of outcome as- & Unclear risk \\
sessment (detection bias) & \\
All outcomes & \\
\hline
\end{tabular}

\begin{tabular}{lll}
$\begin{array}{l}\text { Incomplete outcome data } \\
\text { (attrition bias) } \\
\text { All outcomes }\end{array}$ & Unclear risk & ABI data not provided for the main analysis \\
\hline $\begin{array}{l}\text { Selective reporting (re- } \\
\text { porting bias) }\end{array}$ & Unclear risk & ABI data not provided for the main analysis \\
\hline Other bias & Low risk & Study appears free of other bias \\
\hline
\end{tabular}

Methods Study design: double-blinded, randomised. Cross-over after 3 months


Perhoniemi 1984 (Continued)

\author{
Country: Finland \\ Setting: single centre \\ Intention-to-treat: not mentioned
}

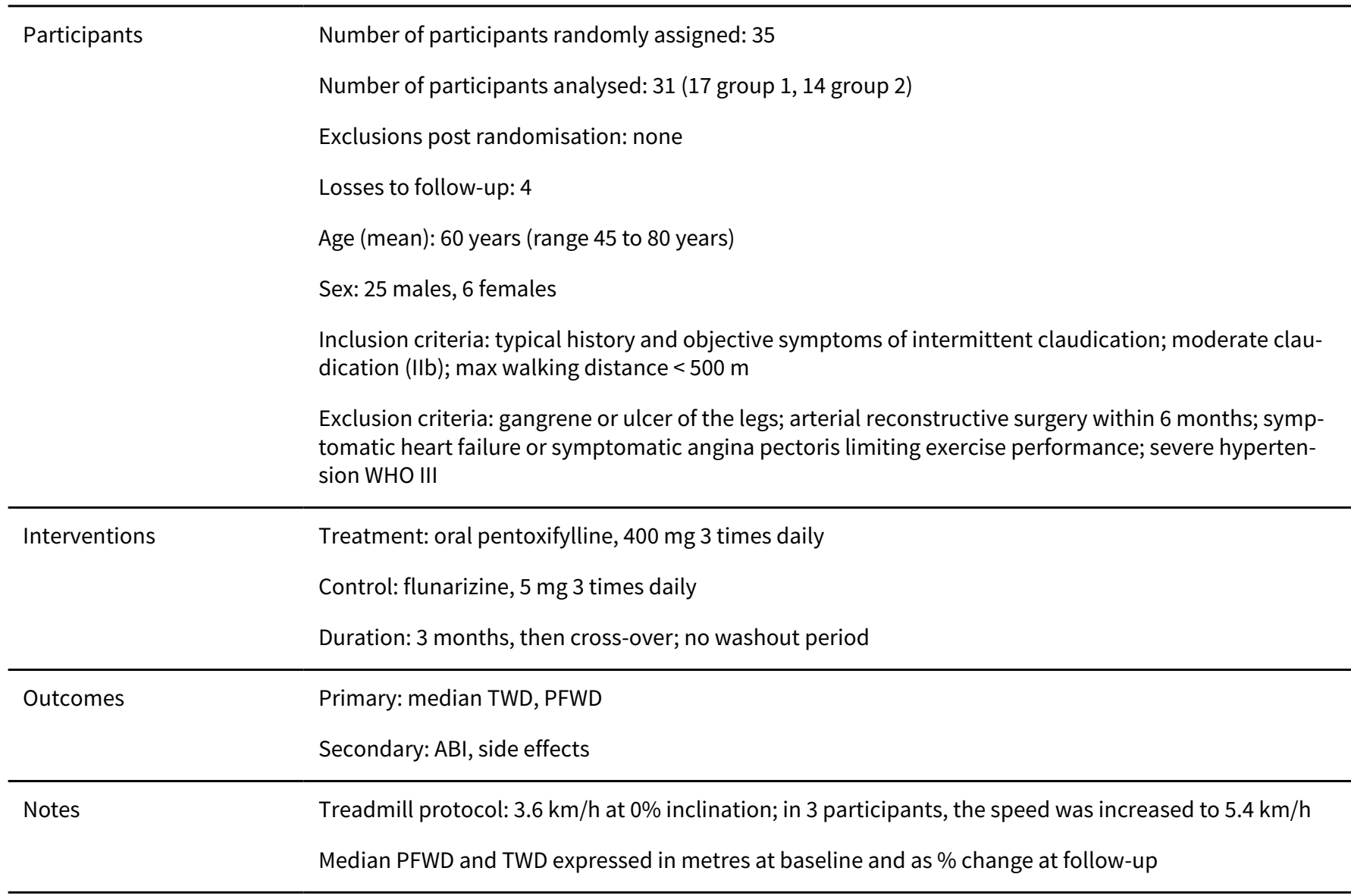

\title{
Risk of bias
}

\section{Bias Authors' judgement Support for judgement}

Random sequence genera- Low risk States 'patients were randomized into two groups according to the system of tion (selection bias) randomized blocks'

\begin{tabular}{lll}
\hline $\begin{array}{l}\text { Allocation concealment } \\
\text { (selection bias) }\end{array}$ & Unclear risk & Not mentioned \\
\hline $\begin{array}{l}\text { Blinding of participants } \\
\text { and personnel (perfor- } \\
\text { mance bias) } \\
\text { All outcomes }\end{array}$ & Unclear risk & $\begin{array}{l}\text { Participants received medication on a 'double-dummy basis'; no other infor- } \\
\text { mation provided }\end{array}$ \\
\hline $\begin{array}{l}\text { Blinding of outcome as- } \\
\text { sessment (detection bias) } \\
\text { All outcomes }\end{array}$ & Unclear risk & Not mentioned \\
\hline $\begin{array}{l}\text { Incomplete outcome data } \\
\text { (attrition bias) } \\
\text { All outcomes }\end{array}$ & Low risk & No incomplete outcome data \\
\hline
\end{tabular}


Perhoniemi 1984 (Continued)

Selective reporting (re- Unclear risk Protocol not available; insufficient information available to permit judgement porting bias)

Other bias Low risk Study appears free of other bias

Porter 1982a

Study design: double-blinded, randomised
Country: USA
Setting: 7 centres
Intention-to-treat: no
Number of participants randomly assigned: 128 (127 + 1 randomised twice), but data presented for 124
participants ( 63 pentoxifylline, 61 placebo)
Number of participants analysed: 82
Exclusions post randomisation: 46
Losses to follow-up: none
Age (mean): pentoxifylline: 62.0 (range 47 to 77 ) years, placebo: 63.5 (range 45 to 81 ) years
Sex: pentoxifylline: 51 males, 12 females, placebo: 50 males, 11 females
Inclusion criteria: IC $\geq 6$ months; able to walk on treadmill $\geq 50 \mathrm{~m}$ at 1.5 mph; $\leq 510 \mathrm{~m}$ in 9.5 minutes at a
speed of 2 mph before onset of claudication; stable TWD - within $20 \%$ change of each other during run
in phase
Exclusion criteria: severe COAD with ischaemic pain at rest, ulceration, gangrene; sympathectomy with-
in previous 6 months; severe peripheral neuropathy; chronic infection; hypersensitivity to methylxan-
thines (caffeine, theophylline, theobromine); women of childbearing potential/pregnant or using oral
contraceptives

Interventions

Treatment: oral pentoxifylline, started at $600 \mathrm{mg}$, increased gradually to $1200 \mathrm{mg}$ at 1 month

Control: placebo

Duration: 24 weeks

Outcomes Primary: geometric mean of $\%$ change in PFWD, TWD

Secondary: side effects

Notes Treadmill protocol: $1.5 \mathrm{mph}$ at $7 \%$ inclination

PFWD and TWD expressed as geometric mean of \% change

Reich 1984 presents the same study, and an ITT analysis of this study is reported in Gillings 1987

\section{Risk of bias}

\begin{tabular}{lll}
\hline Bias & Authors' judgement & Support for judgement \\
\hline $\begin{array}{l}\text { Random sequence genera- } \\
\text { tion (selection bias) }\end{array}$ & Unclear risk & States 'randomization was stratified by clinic'; no other information provided \\
\hline
\end{tabular}


Porter 1982a (Continued)

\begin{tabular}{|c|c|c|}
\hline $\begin{array}{l}\text { Allocation concealment } \\
\text { (selection bias) }\end{array}$ & Unclear risk & Not mentioned \\
\hline $\begin{array}{l}\text { Blinding of participants } \\
\text { and personnel (perfor- } \\
\text { mance bias) } \\
\text { All outcomes }\end{array}$ & Low risk & Reports the use of visibly identical placebo capsules \\
\hline $\begin{array}{l}\text { Blinding of outcome as- } \\
\text { sessment (detection bias) } \\
\text { All outcomes }\end{array}$ & Unclear risk & Not mentioned \\
\hline $\begin{array}{l}\text { Incomplete outcome data } \\
\text { (attrition bias) } \\
\text { All outcomes }\end{array}$ & Low risk & No incomplete outcome data \\
\hline $\begin{array}{l}\text { Selective reporting (re- } \\
\text { porting bias) }\end{array}$ & Unclear risk & Protocol not available; insufficient information available to permit judgement \\
\hline Other bias & Low risk & Study appears free of other bias \\
\hline
\end{tabular}

\section{Porter 1982b}

Study design: double-blinded, randomised
Country: USA
Setting: single
Intention-to-treat: not mentioned

\section{Participants}

Number of participants randomly assigned: 26

Number of participants analysed: 22 (11 in each group)

Exclusions post randomisation: 4

Losses to follow-up: none

Age (mean): 64 years in total group

Sex: 20 males, 6 females

Inclusion criteria: minimal walking distance $>50 \mathrm{~m}$ and $<200 \mathrm{~m}$; lower extremity intermittent claudication); able to walk on a treadmill

Exclusion criteria: ischaemic rest pain; ulceration; sympathectomy within 6 months;

severe neuropathy; hypersensitivity to methylxanthines; females of childbearing potential; concomitant drugs known to have any arterial effect; peripheral vasodilators in the previous 3 months; variance $>20 \%$ in walking distance at the last 2 visits

Interventions

Treatment: oral pentoxifylline, $600 \mathrm{mg}$ in first week, $800 \mathrm{mg}$ in second week, $1000 \mathrm{mg}$ in third week, then $1200 \mathrm{mg} / \mathrm{d}$ fourth to $24 \mathrm{th}$ week

Control: placebo

Duration: 24 weeks 
Porter 1982b (Continued)

\begin{tabular}{ll} 
Outcomes & Primary: TWD, PFWD \\
& Secondary: side effects \\
\hline Notes & Treadmill protocol: $1.5 \mathrm{mph}$ at $7 \%$ inclination \\
& PFWD and TWD expressed in metres only
\end{tabular}

\section{Risk of bias}

\begin{tabular}{|c|c|c|}
\hline Bias & Authors' judgement & Support for judgement \\
\hline $\begin{array}{l}\text { Random sequence genera- } \\
\text { tion (selection bias) }\end{array}$ & Unclear risk & States 'randomised'; no other information provided \\
\hline $\begin{array}{l}\text { Allocation concealment } \\
\text { (selection bias) }\end{array}$ & Unclear risk & Not mentioned \\
\hline $\begin{array}{l}\text { Blinding of participants } \\
\text { and personnel (perfor- } \\
\text { mance bias) } \\
\text { All outcomes }\end{array}$ & Low risk & $\begin{array}{l}\text { States 'Placebo- and drug-treated patients received identical-appearing cap- } \\
\text { sules on the same time schedule' }\end{array}$ \\
\hline $\begin{array}{l}\text { Blinding of outcome as- } \\
\text { sessment (detection bias) } \\
\text { All outcomes }\end{array}$ & Unclear risk & Not mentioned \\
\hline $\begin{array}{l}\text { Incomplete outcome data } \\
\text { (attrition bias) } \\
\text { All outcomes }\end{array}$ & Low risk & No incomplete outcome data \\
\hline $\begin{array}{l}\text { Selective reporting (re- } \\
\text { porting bias) }\end{array}$ & Unclear risk & Protocol not available; insufficient information available to permit judgement \\
\hline Other bias & Low risk & Study appears free of other bias \\
\hline
\end{tabular}

\section{Schellong 2012}

Study design: double-blind, randomised controlled trial; parallel assignment
Country: Germany
Setting: multi-site
Intention-to-treat: yes: participants who received $\geq 1$ dose of trial medication and who had $\geq 1$ valid
measurement of pain-free walking distance under therapy
Number of participants randomly assigned: 561 (pentoxifylline 285, alprostadil 276)
Number of participants analysed: 541 (pentoxifylline 272 , alprostadil 269 ); completed study: 458 (pen-
toxifylline 233, alprostadil 225 )
Exclusions post randomisation: 103 (pentoxifylline 52 , alprostadil 51 )
Losses to follow-up: 4 (pentoxifylline 3 , alprostadil 1 )
Age (mean \pm SD): $66.5 \pm 8.7$ years (pentoxifylline $66.8 \pm 8.8$ years, alprostadil $66.3 \pm 8.6$ years)


Inclusion criteria: individuals with peripheral arterial occlusive disease (PAOD) of the lower extremity in Fontaine stage II; maximum walking distance on the treadmill ( $12 \%, 3 \mathrm{~km} / \mathrm{h})$ between $30 \mathrm{~m}$ and $150 \mathrm{~m}$; stable intermittent claudication $\geq 6$ months standing with no acute shortening of walking distance over the past 3 months; stenoses or occlusions below femoral bifurcation (above-knee or below-knee type) confirmed by duplex US or angiography; ankle/brachial index $\leq 0.90$ with a decrease in systolic ankle pressure $\geq 10 \%$ after maximum loading (maximum walking distance on the treadmill at $3 \mathrm{~km} / \mathrm{h}: 12 \%$ ); patient physically and mentally capable of participating in the trial; patient age $>40$ years, male and female; patient informed and given ample time and opportunity to think about her/his participation and provided written informed consent; patient willing and able to comply with all trial requirements

Exclusion criteria: surgical or other interventional measures performed on affected extremity and prostaglandin treatment within the 6 months immediately before the trial; rest pain and necroses; systolic ankle pressure < $50 \mathrm{mmHg}$; change in maximum walking distance during 1-week run-in phase $> \pm$ $25 \%$ of baseline; successful physical walking training within the 6 months immediately before the trial; inflammatory vascular disease; polyneuropathy in diabetes mellitus; disease limiting walking distance (arthrosis, inflammatory disease of the joints, neurological disease, disease of the vertebral column, cardiopulmonary disease); history of pulmonary oedema; myocardial infarction within previous 6 months; pregnancy or nursing; known hypersensitivity to any components of trial medication or comparative drug; renal insufficiency, compensated retention (creatinine $>2.0 \mathrm{mg} / \mathrm{dL}$ ); severe retinal haemorrhage; massive haemorrhage; known existing malignant disease; vasoactive concomitant medication (e.g. naftidrofuryl, pentoxifylline, buflomedil, cilostazol) or other prostaglandins; untreated or uncontrolled hypertension (systolic blood pressure $\geq 180 \mathrm{mmHg}$, diastolic blood pressure $\geq 110$ $\mathrm{mmHg}$ ); previous participation in the present trial ly IV infusion of 3 ampoules $(20 \mu \mathrm{g})$ prostaglandin E1 in 50 to $250 \mathrm{~mL}$ physiological saline solution over 2 hours); 4-week interval treatment period ( 2 times weekly IV infusion of 3 ampoules $(20 \mu \mathrm{g})$ of prostaglandin E1 in 50 to $250 \mathrm{~mL}$ physiological saline solution over 2 hours); received placebo tablets mimicking schedule of pentoxifylline

Control: pentoxifylline: Trental, 8 weeks of 2-times-daily $600 \mathrm{mg}$ tablets; received placebo infusions of saline mimicking the schedule of alprostadil

Duration: 8 weeks

\begin{tabular}{ll}
\hline Outcomes & Pain-free walking distance, total walking distance, quality of life (PAVK 86 questionnaire), side effects \\
\hline Notes & Treadmill test: $12 \%$ grade and $3 \mathrm{~km} / \mathrm{h}$ \\
& $\begin{array}{l}\text { All data were retrieved from the ClinicalTrials.gov website, which offered no actual walking distances - } \\
\text { only ratios - and no statistical analyses. A full report of the study including outcomes is currently being } \\
\text { worked on by trialists and should provide additional information on bias issues and outcome data }\end{array}$
\end{tabular}

\section{Risk of bias}

\begin{tabular}{lll}
\hline Bias & Authors' judgement & Support for judgement \\
\hline $\begin{array}{l}\text { Random sequence genera- } \\
\text { tion (selection bias) }\end{array}$ & Unclear risk & $\begin{array}{l}\text { Not enough information given to determine adequate random sequence gen- } \\
\text { eration }\end{array}$ \\
\hline $\begin{array}{l}\text { Allocation concealment } \\
\text { (selection bias) }\end{array}$ & Unclear risk & Not enough information given to determine adequate allocation concealment \\
\hline $\begin{array}{l}\text { Blinding of participants } \\
\begin{array}{l}\text { and personnel (perfor- } \\
\text { mance bias) }\end{array}\end{array}$ & Low risk & $\begin{array}{l}\text { Double-blind of participants and investigator using adequate techniques to } \\
\text { maintain blind }\end{array}$ \\
\hline
\end{tabular}


Schellong 2012 (Continued)

Blinding of outcome as- Unclear risk Blinding of outcome assessors not discussed in abstract sessment (detection bias)

All outcomes

$\begin{array}{ll}\begin{array}{l}\text { Incomplete outcome data } \\ \text { (attrition bias) }\end{array} & \text { Low risk } \\ \text { All outcomes } & \begin{array}{l}\text { All randomly assigned participants were accounted for, and intention-to-treat } \\ \text { analysis included nearly all participants; detailed table given to describe exclu- } \\ \text { sions and loss to follow-up, although additional information should be provid- } \\ \text { ed regarding when these participants dropped out of the study }\end{array}\end{array}$

\begin{tabular}{|c|c|c|}
\hline $\begin{array}{l}\text { Selective reporting (re- } \\
\text { porting bias) }\end{array}$ & Low risk & All initially indicated outcomes were reported \\
\hline \multirow[t]{2}{*}{ Other bias } & Unclear risk & $\begin{array}{l}\text { Authors of the study reported that limitations of the study include early termi- } \\
\text { nation, leading to small numbers of participants analysed, and technical prob- } \\
\text { lems with measurement, leading to unreliable or uninterpretable data }\end{array}$ \\
\hline & & $\begin{array}{l}\text { Although the work is sponsored by UCB Pharma, it has been indicated that the } \\
\mathrm{PI} \text { of the study is not employed by the sponsor, and that the sponsor cannot } \\
\text { change communications or publications about the project }\end{array}$ \\
\hline
\end{tabular}

Volker 1978

\begin{tabular}{l} 
Study design: double-blinded, randomised \\
Country: Germany \\
Setting: single centre \\
Intention-to-treat: yes \\
\hline
\end{tabular}

Number of participants randomly assigned: 50 (25 in each arm)
Number of participants analysed: 50
Exclusions post randomisation: none
Losses to follow-up: none
Age: range 56 to 65 years
Sex: pentoxifylline: 18 males, 7 females, placebo: 17 males, 8 females
Inclusion criteria: Fontaine stage II, walking distance $<600$ m; no vasoactive substances allowed
Exclusion criteria: none reported

Interventions Treatment: oral pentoxifylline, $400 \mathrm{mg} 3$ times daily

Control: placebo

Duration: 4 weeks

\begin{tabular}{ll}
\hline Outcomes & Primary: mean PFWD \\
& Secondary: quality of life, side effects \\
\hline Notes & Treadmill protocol: not specified \\
& Mean PFWD expressed in metres only
\end{tabular}


Volker 1978 (Continued)

Risk of bias

\begin{tabular}{|c|c|c|}
\hline Bias & Authors' judgement & Support for judgement \\
\hline $\begin{array}{l}\text { Random sequence genera- } \\
\text { tion (selection bias) }\end{array}$ & Unclear risk & $\begin{array}{l}\text { Randomly assigned according to admission into the study; no other informa- } \\
\text { tion provided }\end{array}$ \\
\hline $\begin{array}{l}\text { Allocation concealment } \\
\text { (selection bias) }\end{array}$ & Unclear risk & Not mentioned \\
\hline $\begin{array}{l}\text { Blinding of participants } \\
\text { and personnel (perfor- } \\
\text { mance bias) } \\
\text { All outcomes }\end{array}$ & Unclear risk & Reported 'double-blind'; no other information provided \\
\hline $\begin{array}{l}\text { Blinding of outcome as- } \\
\text { sessment (detection bias) } \\
\text { All outcomes }\end{array}$ & Unclear risk & Not mentioned \\
\hline $\begin{array}{l}\text { Incomplete outcome data } \\
\text { (attrition bias) } \\
\text { All outcomes }\end{array}$ & Low risk & No incomplete outcome data \\
\hline $\begin{array}{l}\text { Selective reporting (re- } \\
\text { porting bias) }\end{array}$ & Unclear risk & Protocol not available; insufficient information available to permit judgement \\
\hline Other bias & Low risk & Study appears free of other bias \\
\hline
\end{tabular}

ABI: ankle-brachial index.

ABPI: ankle-brachial pressure index.

GI: gastrointestinal.

MI: myocardial infarction.

SFA: superficial femoral artery.

PAD: peripheral arterial disease.

ACD: absolute claudication distance.

WIQ: walking impairment questionnaire.

SF36: Short Form 36.

QoL: quality of life.

COAD: chronic occlusive artery disease.

tds: 3 times daily.

PFWD: pain-free walking distance.

SD: standard deviation.

TWD: total walking distance.

Characteristics of excluded studies [ordered by study ID]

\begin{tabular}{ll}
\hline Study & Reason for exclusion \\
\hline Bieron 2005 & Not double-blinded \\
\hline Ciuffetti 1991 & Looked at biochemical properties, not TWD or PFWD \\
\hline Dawson 1999 & Single-blinded study \\
\hline Dettori 1989 & $\begin{array}{l}\text { Single-blinded for acenocoumarol; therefore no true double-blinding of all trial agents. Outcomes } \\
\text { measured in time, not distance }\end{array}$ \\
\hline
\end{tabular}

Pentoxifylline for intermittent claudication (Review)

Copyright $\odot 2015$ The Cochrane Collaboration. Published by John Wiley \& Sons, Ltd. 


\begin{tabular}{|c|c|}
\hline Study & Reason for exclusion \\
\hline Ehrly 1986 & Different outcome measures such as muscle tissue 02 pressure \\
\hline Ehrly 1987 & Different outcome measures such as muscle tissue 02 pressure \\
\hline Farkas 1993 & Duration of therapy only 2 weeks \\
\hline Fossat 1995 & Different outcome measures such as leucocyte activation \\
\hline Guest 2005 & Cost comparison with no clinical outcomes \\
\hline Hepp 1996 & Not double-blinded \\
\hline Horowitz 1982 & Variable doses of pentoxifylline \\
\hline Incandela 2002 & Looked at microcirculatory parameters \\
\hline Kellner 1976 & Participants with Fontaine stage II and III; results for the 2 groups not presented separately \\
\hline Luk'Janov 1995 & $\begin{array}{l}\text { Different outcome measures such as haemorheologic and haemodynamic measures evaluated; } \\
\text { minimal data on walking distance }\end{array}$ \\
\hline Milio 2003 & Not double-blinded \\
\hline Milio 2006 & Single-blinded study \\
\hline Panchenko 1997 & Open study - no blinding \\
\hline Pignoli 1985 & Not double-blinded \\
\hline Poggesi 1985 & Different outcomes such as circulatory changes and prostaglandin synthesis \\
\hline Regenthal 1991 & Not double-blinded \\
\hline Reilly 1987 & All included participants single-blinded after first 8 weeks; therefore no true randomisation \\
\hline Rodin 1998 & Not a double-blinded clinical trial \\
\hline Rodin 1998a & Not a double-blinded clinical trial \\
\hline Roekaerts 1984 & Participants with Fontaine stage II and III; results not presented separately for the 2 groups \\
\hline Rudofsky 1987 & Only 1 to 2 weeks of treatment provided \\
\hline Rudofsky 1988 & Only 2 weeks of treatment provided \\
\hline Rudofsky 1989 & Only 2 weeks of treatment provided \\
\hline Scheffler 1991 & Not a double-blinded study. Training for participants provided \\
\hline Scheffler 1994 & Not a double-blinded study. Comparison with exercise performed \\
\hline Schubotz 1976 & Participants with symptoms of critical limb ischaemia \\
\hline Shustov 1997 & Open controlled trial \\
\hline
\end{tabular}




\begin{tabular}{ll}
\hline Study & Reason for exclusion \\
\hline Singh 2009 & Open study \\
\hline Strano 1984 & Participants with stage Fontaine stage II and III; results not presented separately for the 2 groups \\
\hline Strano 2002 & Open study \\
\hline Thomson 1990 & Participants with symptoms of critical limb ischaemia \\
\hline Tonak 1977 & Participants with Fontaine stage II and III; results not presented separately for the 2 groups \\
\hline Triebe 1992 & Open study \\
\hline Tsang 1994 & Different outcome measures such as albumin/creatinine ratio, etc. \\
\hline Wang 2003 & Different outcome measures such as lipoprotein cholesterol concentrations \\
\hline
\end{tabular}

\section{ADDITIONAL TABLES}




\begin{tabular}{|c|c|c|c|c|c|c|c|c|c|c|c|c|c|c|c|}
\hline Study & Dose & Dur & Pxt & Plc & Pxo & SD & Px-E & SD & \%age & $\begin{array}{l}\text { SDIC0 } \\
\%\end{array}$ & SD & Plc-E & SD & \%age & $\begin{array}{l}\text { SDiff } \\
\%\end{array}$ \\
\hline Cesarone $2002 \mathrm{~b}$ & 1600 & 40 & 88 & 90 & 43 & 70 & 166 & 220 & 286.0 & 42 & 10 & 155 & 440 & 269.0 & 17.0 \\
\hline Creager 2008 & 1200 & 24 & 86 & 84 & 118 & 83 & & & 34.3 & 120 & 88 & & & 21.2 & 13.1 \\
\hline Dawson 2000 & 1200 & 24 & 232 & 239 & 126 & 79 & 202 & 139 & 60.3 & 122 & 69 & 180 & 115 & 47.5 & 12.8 \\
\hline Donaldson 1984 & 600 & 8 & 40 & 40 & 108.2 & 85.1 & 119.3 & 73.7 & 10.3 & 97.1 & 66.2 & 129 & 109. & 432.9 & -22.6 \\
\hline Ernst 1992 & 1200 & 12 & 20 & 20 & 144 & 54 & 364 & 236 & 152.8 & 134 & 64 & 384 & 228 & 186.6 & -33.8 \\
\hline $\begin{array}{l}\text { Gallus } 1985 \\
\text { cross-over phase I* }\end{array}$ & 1200 & 8 & 19 & 19 & 27.1 & & 47.7 & & 76.0 & 28.7 & & 48.3 & & 68.2 & 7.8 \\
\hline Kiesewetter 1988 & 1200 & 8 & 20 & 20 & & & $\begin{array}{l}(+44 \\
\mathrm{m})\end{array}$ & & 43.6 & & & $(+3 \mathrm{~m})$ & & 3.1 & 40.5 \\
\hline Lindgarde 1989 & 1200 & 26 & 76 & 74 & 77 & 4 & & & 80 & 179 & 4 & & & 60 & 120 \\
\hline Porter 1982a & 1200 & 24 & 40 & 42 & 111 & & 195 & & 76 & 117 & & 180 & & 54 & 22 \\
\hline Porter 1982b & 1200 & 24 & 11 & 11 & 54.7 & & 114.2 & & 108.8 & 100.8 & & 136 & & 34.9 & 73.9 \\
\hline Volker 1978 & 1200 & 4 & 25 & 25 & 331.2 & 22.7 & 464.6 & 23.6 & 040.3 & 230.4 & 15.0 & 290.2 & 16.9 & 25.9 & 14.4 \\
\hline $\begin{array}{l}\text { Dur: duration in week } \\
\text { Pxt: pentoxifylline san } \\
\text { Plc: placebo sample si } \\
\text { Px0: baseline walking } \\
\text { SD: standard deviatio } \\
\text { Px-E: end walking dist } \\
\text { \%age: percentage imp } \\
\text { SD\%: standard deviat } \\
\text { Plc0: baseline walking } \\
\text { Plc-E: end walking dis } \\
\text { Diff: difference in perc } \\
\text { *: data presented for }\end{array}$ & $\begin{array}{l}\text { for pen } \\
\text { pentoxi } \\
\text { ng dista } \\
\text { rovem } \\
\text { for pla } \\
\text { placeb } \\
\text { ment fo }\end{array}$ & $\begin{array}{l}\text { ylline } \\
\text { e grou } \\
\text { walk } \\
\text { grour } \\
\text { up. } \\
\text { toxify }\end{array}$ & $\begin{array}{l}\text { group } \\
\text { up. } \\
\text { ing di } \\
\text { p. } \\
\text { Iline a }\end{array}$ & ance. & bo gr & & & & & & & & & & \\
\hline
\end{tabular}




\begin{tabular}{|c|c|c|c|c|c|c|c|c|c|c|c|c|c|c|c|}
\hline Study & Dose & Dur & Pxt & Plc & Pxo & SD & PX-E & SD & \%age & $\begin{array}{l}\text { SPIc0 } \\
\%\end{array}$ & SD & Plc-E & SD & \%age & $\begin{array}{l}\text { SDiff } \\
\%\end{array}$ \\
\hline Belcaro 2002 & 1600 & 24 & 27 & 26 & 56 & 8 & 161 & 21 & 187.5 & 59 & 12 & 103 & 22 & 74.6 & 112.9 \\
\hline Bollinger 1977 & 600 & 8 & 10 & 9 & 226 & 33.6 & 697 & 125 & 3208.0 & 177 & 29.2 & 270 & 201. & 852.5 & 155.9 \\
\hline Cesarone 2002b & 1600 & 40 & 88 & 90 & 87 & 11 & 287 & 340 & 229.9 & 98 & 14 & 180 & 120 & 83.7 & 146.2 \\
\hline Creager 2008 & 1200 & 24 & 86 & 84 & 316 & 191 & & & 13.9 & 292 & 161 & & & 3.3 & 10.6 \\
\hline Dawson 2000 & 1200 & 24 & 232 & 239 & 238 & 119 & 308 & 183 & 29.4 & 234 & 119 & 300 & 180 & 28.2 & 1.2 \\
\hline De Sanctis 2002a & 1800 & 52 & 56 & 45 & 66 & 13 & 267 & 38 & 304.5 & 67 & 11 & 188 & 19 & 180.6 & 123.9 \\
\hline De Sanctis $2002 b$ & 1800 & 52 & 75 & 60 & 554 & 66 & 943 & 78 & 70.2 & 576 & 71 & 755 & 67 & 31.1 & 39.1 \\
\hline Di Perri 1983 & 1200 & 8 & 12 & 12 & 223 & 20 & 359 & 29 & 61.00 & 208 & 24.6 & 215 & 25 & 3.4 & 57.6 \\
\hline \multicolumn{16}{|c|}{ cross-over phase I* } \\
\hline Ernst 1992 & 1200 & 12 & 20 & 20 & 166 & 58 & 504 & 257 & 203.6 & 151 & 58 & 420 & 229 & 178.14 & 25.5 \\
\hline Gallus 1985 & 1200 & 8 & 19 & 19 & 67.8 & & 90.4 & & 33.3 & 87.9 & & 99.8 & & 13.5 & 19.8 \\
\hline \multicolumn{16}{|l|}{ cross-over phase I* } \\
\hline Lee 2001 & 800 & 8 & 17 & 16 & 114 & 51 & 147 & 81 & 28.9 & 116 & 56 & 121 & 62 & 4.3 & 24.6 \\
\hline Lindgarde 1989 & 1200 & 26 & 76 & 74 & 132 & 9 & & & 50.0 & 9155 & 11 & & & 29.0 & 821.0 \\
\hline Porter 1982a & 1200 & 24 & 42 & 40 & 172 & & 268 & & 55.8 & 181 & & 250 & & 38.1 & 17.7 \\
\hline Porter 1982b & 1200 & 24 & 11 & 11 & 92.1 & & 156 & & 69.4 & 182.1 & & 187.4 & & 2.9 & 66.5 \\
\hline $\begin{array}{l}\text { Dur: duration in we } \\
\text { Pxt: pentoxifylline s } \\
\text { Plc: placebo sampl } \\
\text { Px0: baseline walki } \\
\text { SD: standard deviat } \\
\text { Px-E: end walking d } \\
\text { \%age: percentage i } \\
\text { SD\%: standard devi }\end{array}$ & $\begin{array}{l}\text { pentoxi } \\
\text { toxifylli } \\
\text { distance } \\
\text { ement }\end{array}$ & $\begin{array}{l}\text { grou } \\
\text { kup. } \\
\text { king }\end{array}$ & up. & & & & & & & & & & & & \\
\hline
\end{tabular}




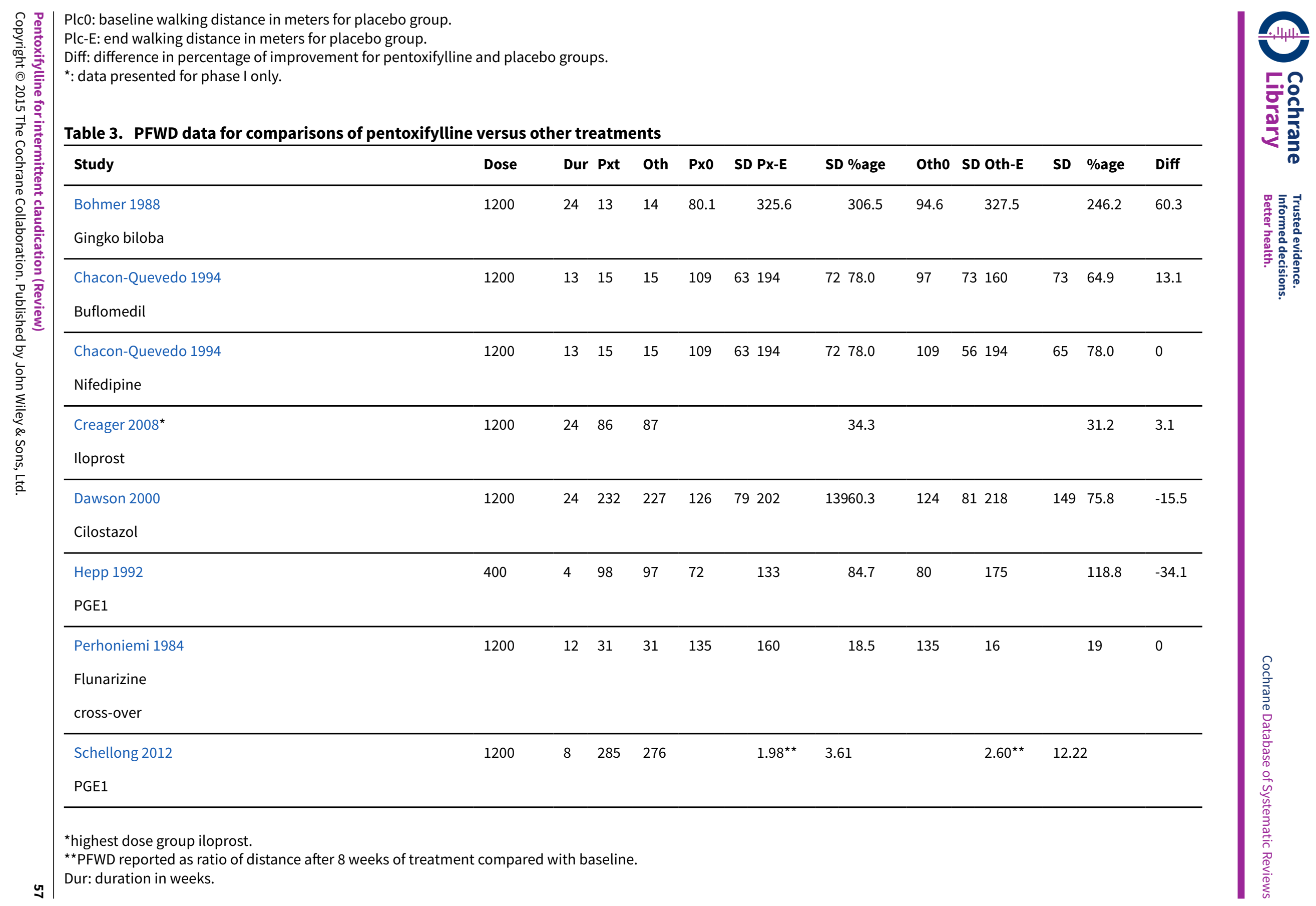


Pxt: pentoxifylline sample size.

Oth: other treatment group sample size.

Px0: baseline walking distance in meters for pentoxifylline group.

SD: standard deviation.

Px-E: end walking distance in meters for pentoxifylline group.

\%age: percentage improvement in walking distance.

Oth0: baseline walking distance in meters for other treatment group.

Oth-E: end walking distance in meters for other treatment group.

Diff: difference in percentage improvement for pentoxifylline and other treatment groups.

Table 4. TWD data for comparisons of pentoxifylline versus other treatments

\begin{tabular}{|c|c|c|c|c|c|c|c|c|c|c|c|}
\hline Study & Dose & Dur & Pxt & Oth & Pxo & SD Px-E & SD \%age & Otho & SD Oth-E & SD \%age & Diff \\
\hline Accetto 1982 & 1200 & 8 & 23 & 24 & 132.6 & 193.4 & 45.9 & 163.4 & 168.9 & 3.4 & 42.5 \\
\hline \multicolumn{12}{|l|}{ Nylidrin $\mathrm{HCL}$} \\
\hline Bohmer 1988 & 1200 & 24 & 13 & 14 & 189.5 & 427.3 & 125.5 & 203 & 436.5 & 115.0 & 10.5 \\
\hline \multicolumn{12}{|l|}{ Gingko biloba } \\
\hline \multicolumn{12}{|l|}{ Buflomedil } \\
\hline Chacon-Quevedo 1994 & 1200 & 13 & 15 & 15 & 180 & 67226 & 5725.6 & 186 & 54226 & 4921.5 & 4.1 \\
\hline \multicolumn{12}{|l|}{ Nifedipine } \\
\hline & 1200 & 6 & 45 & 45 & $\begin{array}{l}1 \\
\text { mile }\end{array}$ & 2 miles & 100 & $\begin{array}{l}0.8 \\
\text { miles }\end{array}$ & $\begin{array}{l}1.2 \\
\text { miles }\end{array}$ & 50 & 50 \\
\hline Creager 2008 & 1200 & 24 & 86 & 87 & & & 13.9 & & & 11.2 & 2.7 \\
\hline \multicolumn{12}{|l|}{ Iloprost* } \\
\hline Dawson 2000 & 1200 & 24 & 232 & 227 & 238 & 119308 & 18329.4 & 241 & 123350 & 20945.2 & -15.8 \\
\hline \multicolumn{12}{|l|}{ Cilostazol } \\
\hline Hepp 1992 & 400 & 4 & 98 & 97 & 115 & 190 & 65.2 & 129 & 230 & 78.3 & -13.1 \\
\hline \multicolumn{12}{|l|}{ PGE1 } \\
\hline Lee 2001 & 800 & 8 & 17 & 17 & 114 & $51 \quad 147$ & 8128.9 & 111 & 30145 & 5330.6 & -1.7 \\
\hline
\end{tabular}




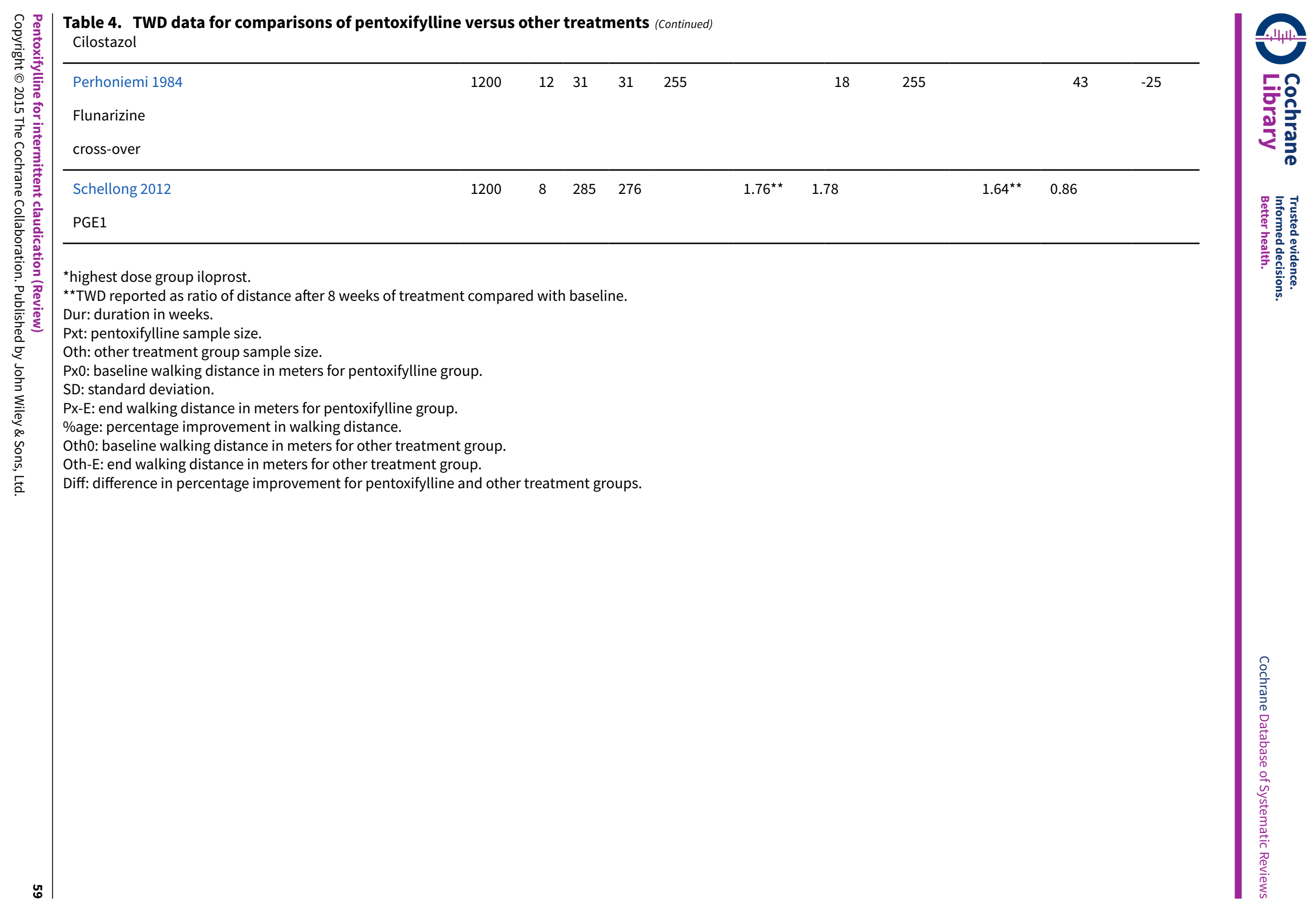




\section{APPENDICES}

\section{Appendix 1. CRS search strategy}

\begin{tabular}{|c|c|c|}
\hline$\# 1$ & MESH DESCRIPTOR Arteriosclerosis & 863 \\
\hline$\# 2$ & MESH DESCRIPTOR Arteriolosclerosis EXPLODE ALL TREES & 0 \\
\hline \#3 & MESH DESCRIPTOR Arteriosclerosis Obliterans & 69 \\
\hline \#4 & MESH DESCRIPTOR Atherosclerosis & 489 \\
\hline \#5 & MESH DESCRIPTOR Arterial Occlusive Diseases & 695 \\
\hline$\# 6$ & MESH DESCRIPTOR Intermittent Claudication & 664 \\
\hline$\# 7$ & MESH DESCRIPTOR Ischemia & 718 \\
\hline \#8 & MESH DESCRIPTOR Peripheral Vascular Diseases EXPLODE ALL TREES & 2072 \\
\hline$\# 9$ & (atherosclero* or arteriosclero* or PVD or PAOD or PAD ):TI,AB,KY & 7440 \\
\hline$\# 10$ & $\begin{array}{l}\left(\left(\text { arter }^{\star} \text { or vascular or vein }{ }^{\star} \text { or veno* } \text { or peripher }^{\star}\right) \text { near3 }\left(\text { occlus }^{\star} \text { or reocclus }{ }^{\star} \text { or re- }\right.\right. \\
\text { occlus }^{\star} \text { or steno* or restenos } \text { or obstruct }^{\star} \text { or lesio* or block* or harden* or stiffen }{ }^{\star} \text { or } \\
\left.\left.\text { obliter }{ }^{\star}\right)\right): T I, A B, K Y\end{array}$ & 6179 \\
\hline \#11 & (peripheral near3 dis $\left.{ }^{\star}\right): \mathrm{TI}, \mathrm{AB}, \mathrm{KY}$ & 2717 \\
\hline$\# 12$ & (claudic* or IC):TI,AB,KY & 2472 \\
\hline \#13 & (isch* or $\mathrm{CLI}$ ):TI,AB,KY & 18739 \\
\hline \#14 & arteriopathic:TI,AB,KY & 7 \\
\hline \#15 & dysvascular*: $\mathrm{TI}, \mathrm{AB}, \mathrm{KY}$ & 9 \\
\hline \#16 & $\begin{array}{l}\text { (leg near3 } \text { occlus }^{\star} \text { or reocclus }{ }^{\star} \text { or re-occlus* or steno* } \text { or restenos }^{\star} \text { or obstruct }^{\star} \text { or lesio* }^{\star} \\
\left.\text { or block } \text { or harden }^{\star} \text { or stiffen }{ }^{\star} \text { or obliter }{ }^{\star}\right) \text { ):TI,AB,KY }\end{array}$ & 75 \\
\hline \#17 & $\begin{array}{l}\text { (limb near3 } \text { occlus }^{\star} \text { or reocclus }{ }^{\star} \text { or re-occlus }{ }^{\star} \text { or steno* } \text { or restenos }^{\star} \text { or obstruct }^{\star} \text { or lesio* }^{\star} \\
\left.\text { or block } \text { or harden }^{\star} \text { or stiffen } \text { or obliter }^{\star}\right) \text { ):TI,AB,KY }\end{array}$ & 110 \\
\hline$\# 18$ & $\begin{array}{l}\left.\text { ((lower near3 extrem }{ }^{\star}\right) \text { near3 }\left(\text { occlus }^{\star} \text { or reocclus }{ }^{\star} \text { or re-occlus }{ }^{\star} \text { or steno* or restenos }{ }^{\star} \text { or }\right. \\
\left.\text { obstruct }^{\star} \text { or lesio* or block }{ }^{\star} \text { or harden }{ }^{\star} \text { or stiffen }{ }^{\star} \text { or obliter }\right) \text { ):TI,AB,KY }\end{array}$ & 70 \\
\hline \#19 & 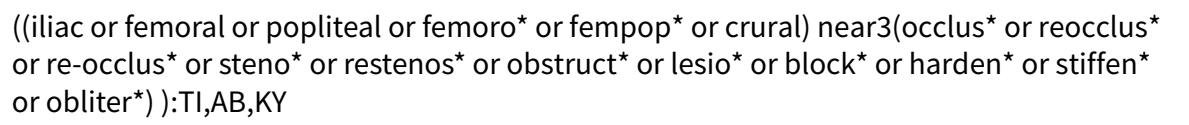 & 734 \\
\hline$\# 20$ & MESH DESCRIPTOR Leg EXPLODE ALL TREES WITH QUALIFIERS BS & 1061 \\
\hline \#21 & MESH DESCRIPTOR Iliac Artery & 135 \\
\hline \#22 & MESH DESCRIPTOR Popliteal Artery & 246 \\
\hline
\end{tabular}


(Continued)

\begin{tabular}{|c|c|c|}
\hline \#23 & MESH DESCRIPTOR Femoral Artery & 723 \\
\hline \#24 & MESH DESCRIPTOR Tibial Arteries & 30 \\
\hline \#25 & 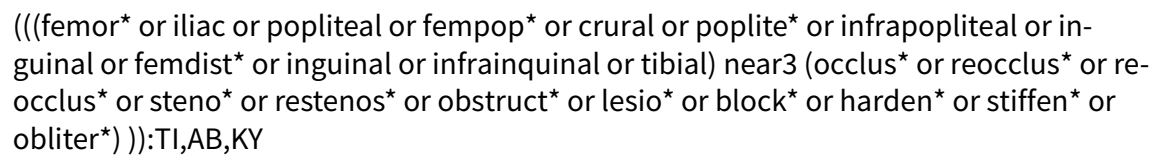 & 858 \\
\hline \#26 & $\begin{array}{l}\# 1 \text { OR \#2 OR \#3 OR \#4 OR \#5 OR \#6 OR \#7 OR \#8 OR \#9 OR \#10 OR \#11 OR \#12 OR \#13 OR } \\
\# 14 \text { OR \#15 OR \#16 OR \#17 OR \#18 OR \#19 OR \#20 OR \#21 OR \#22 OR \#23 OR \#24 OR \#25 }\end{array}$ & 35405 \\
\hline \#27 & MESH DESCRIPTOR Pentoxifylline EXPLODE ALL TREES & 408 \\
\hline \#28 & (pentox* OR oxypent*):TI,AB,KY & 871 \\
\hline \#29 & MESH DESCRIPTOR Phosphodiesterase Inhibitors EXPLODE ALL TREES & 4914 \\
\hline \#30 & (phosphodiesterase near2 inhibitor ${ }^{\star}$ ):TI,AB,KY & 1286 \\
\hline \#31 & BL-191:TI,AB,KY & 5 \\
\hline \#32 & \#27 OR \#28 OR \#29 OR \#30 OR \#31 & 5708 \\
\hline \#33 & \#26 AND \#32 & 703 \\
\hline
\end{tabular}

WHAT'S NEW

\begin{tabular}{lll}
\hline Date & Event & Description \\
\hline 4 May 2015 & New search has been performed & $\begin{array}{l}\text { Searches rerun. One new study excluded and one study that was } \\
\text { previously recorded as 'Ongoing' now recorded as an included } \\
\text { study }\end{array}$ \\
\hline 4 May 2015 & $\begin{array}{l}\text { New citation required but conclusions } \\
\text { have not changed }\end{array}$ & $\begin{array}{l}\text { Searches rerun. One new study excluded and one study that was } \\
\text { previously recorded as 'Ongoing' now recorded as an included } \\
\text { study, with limited data available from ClinicalTrials.gov (com- } \\
\text { parison pentoxifylline vs PGE1). New author added to the review } \\
\text { team. Conclusions not changed }\end{array}$ \\
\hline
\end{tabular}

\section{H I S T ORY}

Protocol first published: Issue 2, 2005

Review first published: Issue 1, 2012

\begin{tabular}{lll}
\hline Date & Event & Description \\
\hline 22 October 2008 & Amended & Converted to new review format \\
\hline
\end{tabular}




\section{CONTRIBUTIONS OF AUTHORS}

For this review update:

RF evaluated studies for inclusion, performed data extraction, assessed risk of bias and updated manuscript text. $\mathrm{KS}$ evaluated studies for inclusion, performed data extraction and assessed risk of bias.

$\mathrm{ES}, \mathrm{MAH}, \mathrm{AB}$ and JM provided editorial support.

\section{DECLARATIONS OF INTEREST}

JM: Chair of NICE guideline development group for PAD and co-author of several cited papers (Meng 2014; Squires 2010; Squires 2011; Stevens 2012).

KS: none known

RF: none known

ES: none known

$\mathrm{MAH}$ : none known

$A B:$ none known

JM: Professor Michaels has received programme funding from the NIHR for research related to vascular disease and has received payments for secondment for committee work from the HTA Prioritisation Panel and the NICE Appraisal Committee, for consultancy from Michaels Consulting Limited (as director of company that provides consultancy for a number of companies - none directly related to the subject of this review) and for a review of practice guidelines from KCE (Belgian Health Care Knowledge Centre)

\section{SOURCES OF SUPPORT}

\section{Internal sources}

- Sheffield Vascular Institute, Northern General Hospital, Sheffield Teaching Hospital, UK.

- School of Health and Related Research (ScHARR), University of Sheffield, UK.

\section{External sources}

- Chief Scientist Office, Scottish Government Health Directorates, The Scottish Government, UK.

The Cochrane Vascular editorial base is supported by the Chief Scientist Office.

\section{DIFFERENCES BETWEEN PROTOCOLAND REVIEW}

To adhere to updated Cochrane guidelines for assessment of bias, we have included an assessment of bias performed using the 'Risk of bias' tool of The Cochrane Collaboration and have removed the Jadad score.

We have removed eight studies from the 'Excluded studies' presented in the previous version of this review, as they were considered not relevant in the light of current Cochrane guidelines.

\section{N DEX TERMS}

\section{Medical Subject Headings (MeSH)}

Ankle Brachial Index; Intermittent Claudication [ ${ }^{\star}$ drug therapy]; Pentoxifylline [ ${ }^{\star}$ therapeutic use]; Platelet Aggregation Inhibitors [*therapeutic use]; Quality of Life; Randomized Controlled Trials as Topic; Vasodilator Agents [*therapeutic use]; Walking

\section{MeSH check words}

Humans 